\title{
1996 Singapore Ground Shock Test
}

Donald W. Murrell and Charles E. Joachim

April 2000 


\title{
US-CE-C Property of the United States Government
}

\section{Singapore Ground Shock Test}

by Donald W. Murrell, Charles E. Joachim

Waterways Experiment Station

U.S. Army Engineer Research and Development Center 3909 Halls Ferry Road

Vicksburg, MS 39180-6199

\section{Final report}

Approved for public release; distribution is unlimited

\section{Research Librory US Army Engineer Research \& Development Cir, COE Waterways Experiment Station Vicksburg, MS}

\author{
Prepared for Lands and Estates Organization \\ Ministry of Defence \\ 1 Depot Road, \#12-05 \\ Singapore 109679 \\ Republic of Singapore
}




\section{Contents}

Preface vii

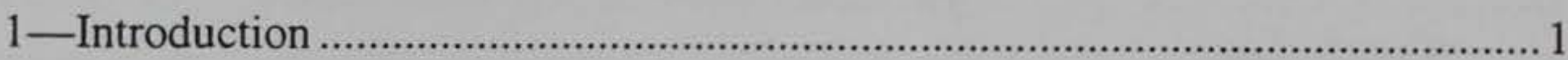

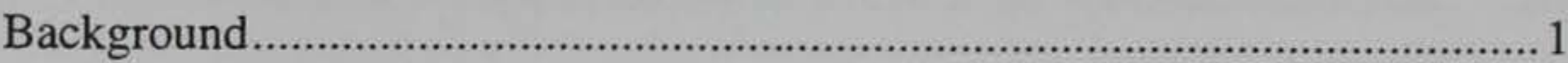

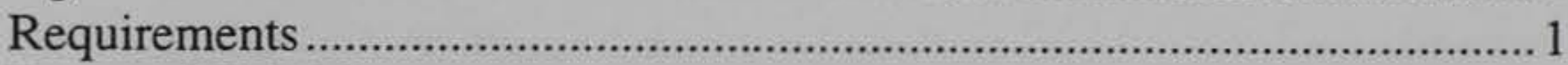

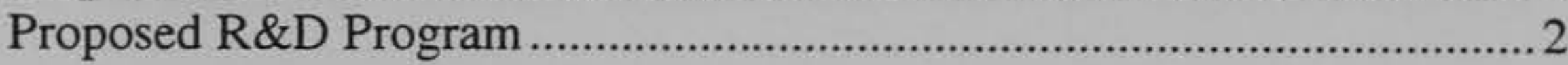

Development of the 1996 Singapore Ground Shock Test........................... 2

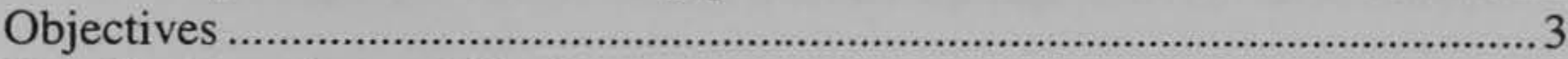

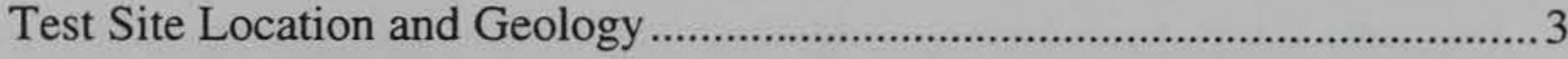

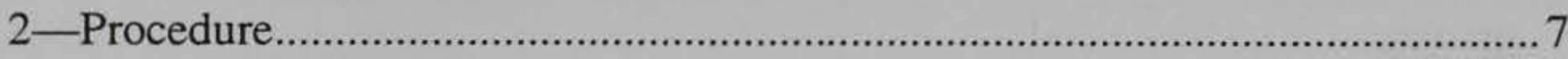

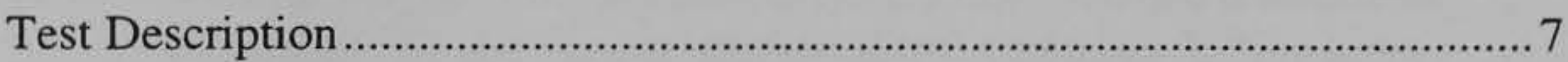

Chamber and Tunnel Dimensions............................................................... 7

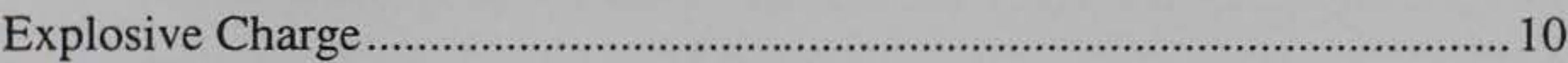

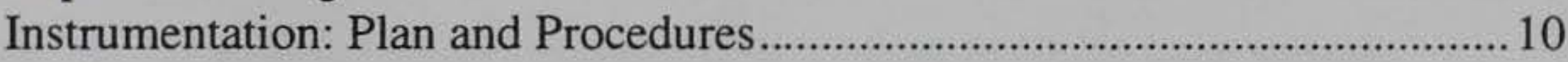

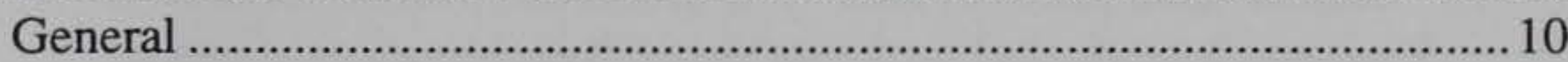

Ground shock measurements ................................................................ 12

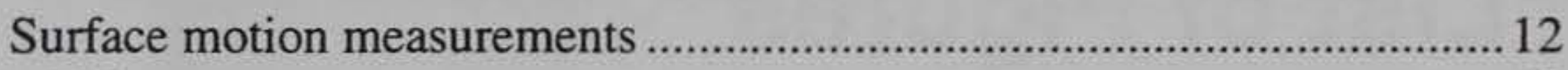

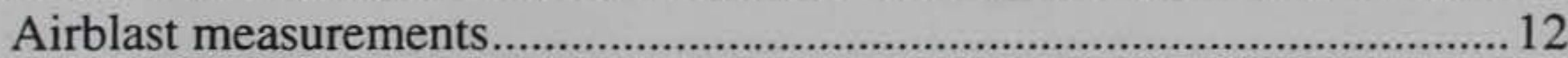

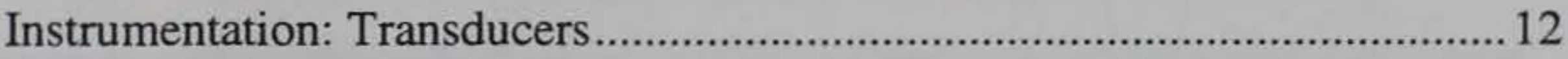

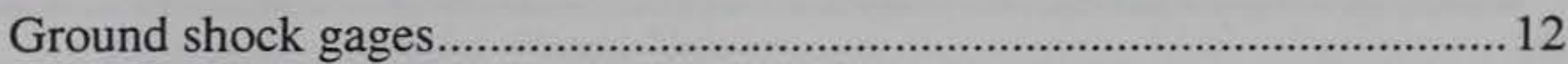

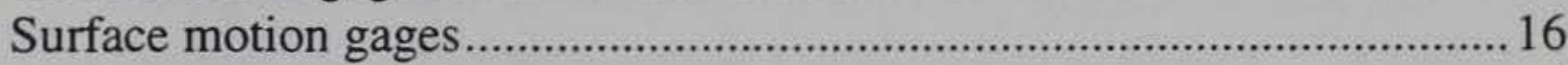

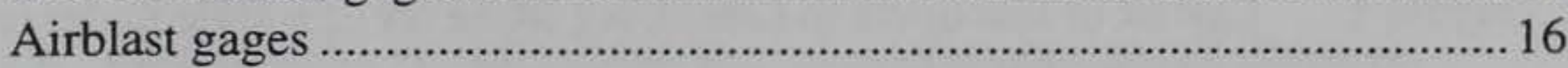

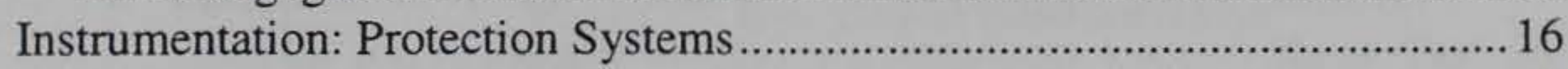

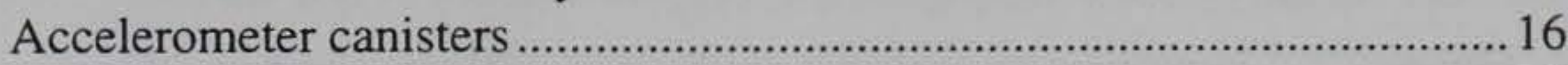

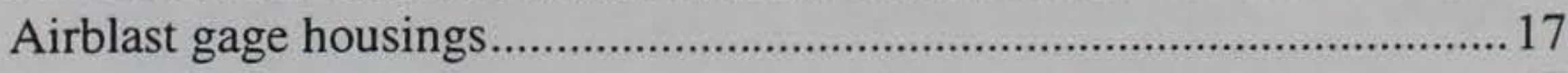

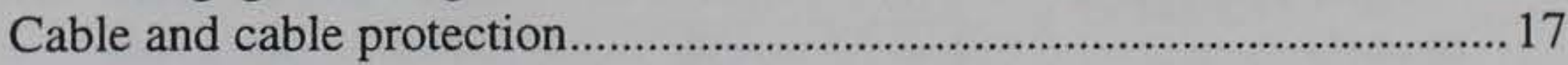

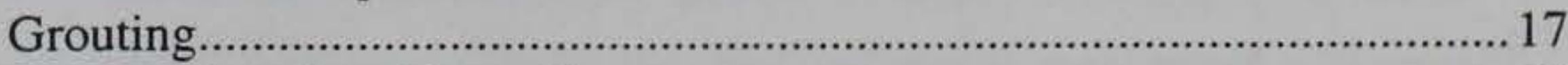

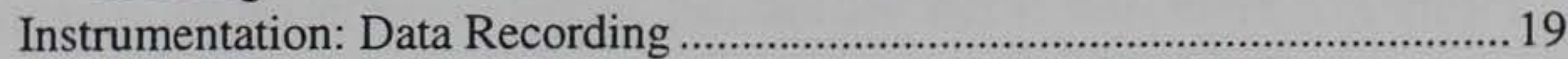

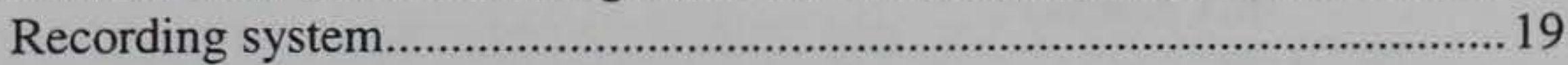

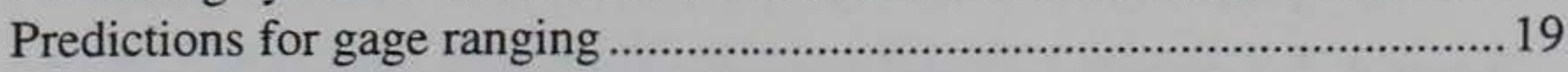

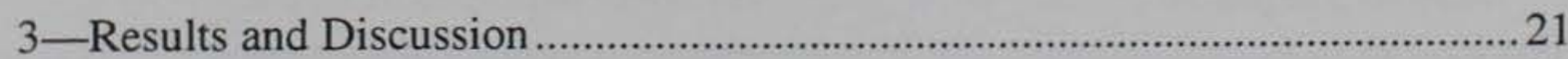

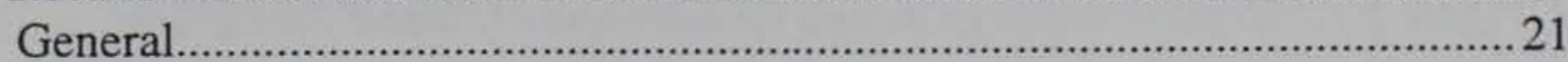

Free-Field Ground Shock Measurements ....................................................... 21

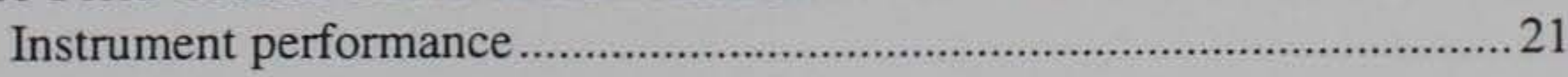




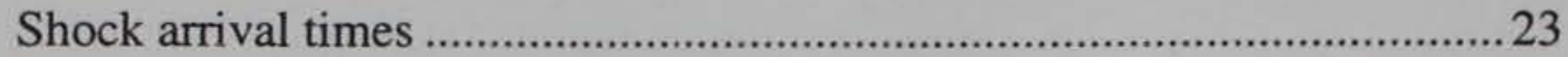

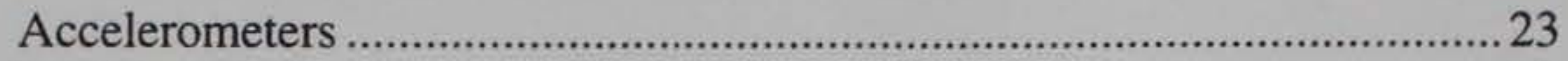

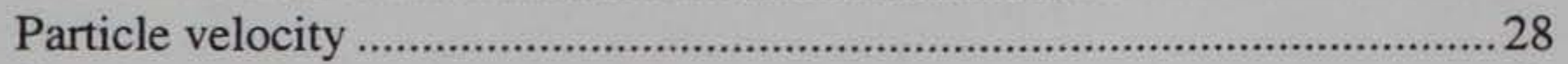

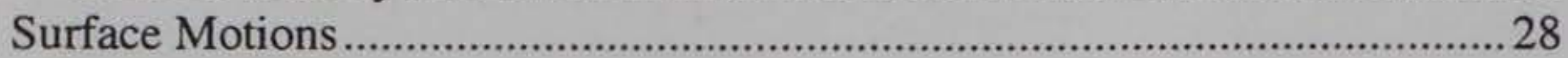

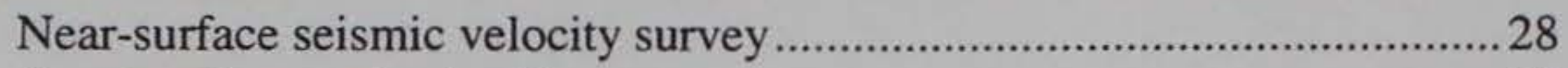

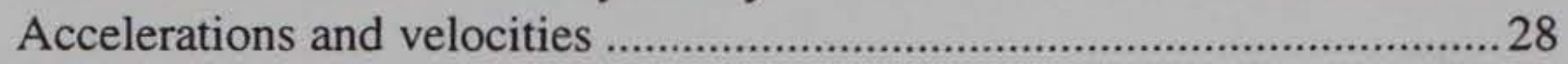

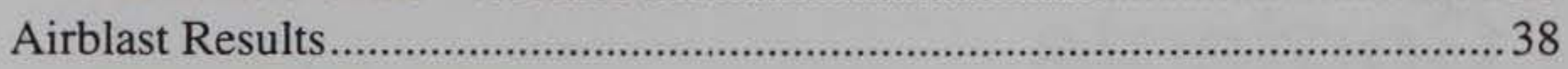

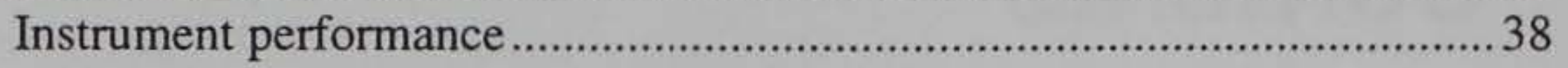

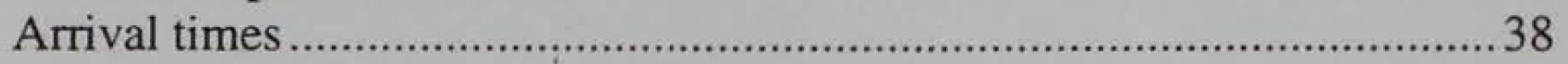

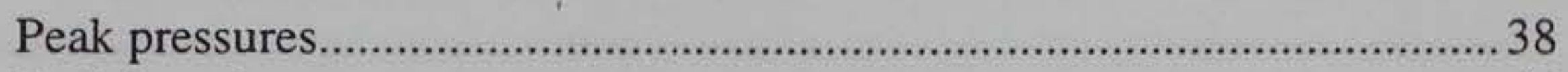

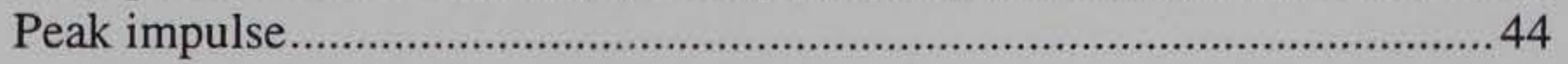

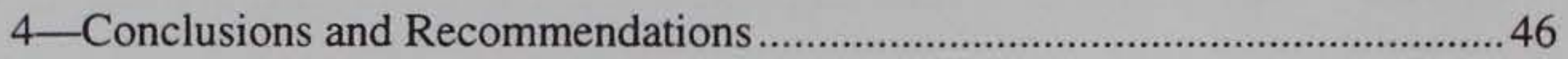

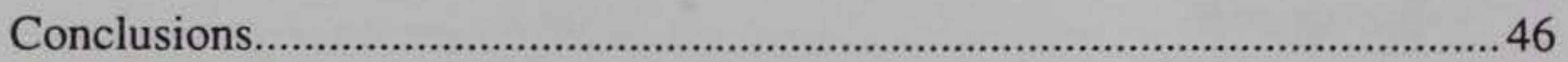

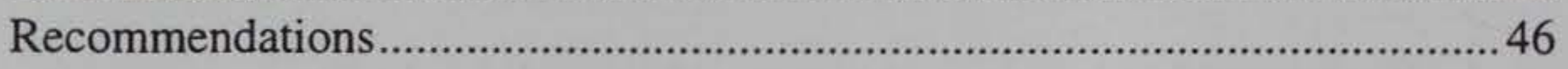

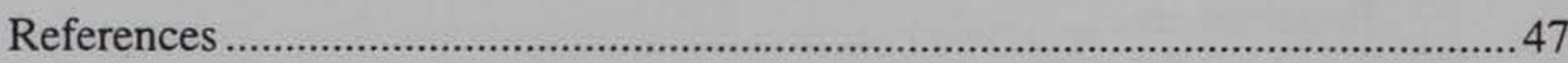

Appendix A: 1996 Singapore Ground Shock Time-Histories .......................... A1

Appendix B: Singapore Ground Shock Test: Airblast Pressure Time-Histories B1

SF 298

\section{List of Figures}

Figure 1. Layout of test drifts in Linchburg Mine for 1/3-scale underground magazine blast effects tests .............................................................. 5

Figure 2. Approximate geologic profile for vertical gage hole above Chamber 2

Figure 3. Front view of sandbag and rock rubble barrier inside the entrance to Chamber 2 ............................................................................... 8

Figure 4. Configuration and dimensions of test chamber (Chamber 2)..............9

Figure 5. Explosive charge design for Singapore Ground Shock Test ..............11 
Figure 6. Ground shock measurement locations in vertical gage hole for Singapore Ground Shock Test .

Figure 7. Seismic sensor and shot point overlay on overburden surface above the Linchburg Mine, Singapore Ground Shock Test.

Figure 8. Airblast gage layout for Singapore Ground Shock Test.

Figure 9. Airblast gage debris shield

Figure 10. Crater in the floor of Chamber 2 produced by the explosive charge detonated for the Singapore Ground Shock Test 22

Figure 11. Ground shock arrival times versus range 25

Figure 12. Scaled peak acceleration versus scaled range 26

Figure 13. Location of U.S. Phase 3 Intermediate-Scale tests

Figure 14. Peak particle velocity versus scaled range

Figure 15. Seismic profile from refraction survey of overburden above test chamber at Linchburg Mine.

Figure 16. Vertical particle velocity-time histories from seismic transducers located on the overburden surface above Chamber 2, Singapore Ground Shock Test.

Figure 17. Horizontal (E-W) particle velocity-time histories from seismic transducers located on the overburden surface above Chamber 2, Singapore Ground Shock Test

Figure 18. Horizontal (N-S) particle velocity-time histories from seismic transducers located on the overburden surface above Chamber 2, Singapore Ground Shock Test

Figure 19. Peak particle velocity (peak to peak) versus horizontal distance from the top of the instrument hole, Singapore Ground Shock Test.36

Figure 20. Peak particle velocity (peak to peak) versus slant distance from the center of the explosive charge, Chamber 2, Singapore Ground Shock Test

Figure 21. Comparison of vertical surface motion particle velocities (open circle symbols) with the radial free-field velocities, all as a function of scaled range from the charge center, Singapore Ground Shock Test 
Figure 22. Airblast shock front arrival time versus distance from rear wall of Chamber 2, Singapore Ground Shock Test.

Figure 23. Typical underground airblast pressure-time history with shock and gas components, Singapore Ground Shock Test.

Figure 24. Peak overpressure versus distance from rear wall of Chamber 2, Singapore Ground Shock Test

Figure 25. Peak overpressure impulse versus distance form real wall of Chamber 2, Singapore Ground Shock test

\section{List of Tables}

Table 1. Results of Grout Sample Properties Tests

Table 2. Free-Field Ground Shock Data Summary

Table 3. Locations of Seismic Surface Motion Gages, Refraction Survey Shot Points, and External Airblast Gages.

Table 4. Seismic Surface Motion Data Summary. 30

Table 5. Airblast Data Summary 39 


\section{Preface}

The Republic of Singapore sponsored this research effort under provisions of the U.S. Army Foreign Military Sales Case No. SN-B-HAA. The study was conducted by the Geomechanics and Explosion Effects Division (GEED), Structures Laboratory (SL), Waterways Experiment Station (WES), U.S. Army Engineer Research and Development Center (ERDC), Vicksburg, MS. The experiments were performed in an underground test area of the Linchburg Mine near Magdalena, NM, in June 1996.

The Program Monitor was Mr. Lim Chee Hiong, Deputy Director, Lands and Estates Organization, Ministry of Defense, Republic of Singapore.

The U.S. Program Manager for this study was Mr. Landon K. Davis, GEED. Mr. Donald W. Murrell was the Project Engineer, and Mr. Charles E. Joachim was the Test Manager. Messrs. Murrell and Joachim are the authors of this report. WES staff members assisting in the study were Messrs. T. G. Ray, and B. P. Dent, Jr., GEED, and Messrs. F. D. Shirley, and G. S. Cronia, Jr., Instrumentation Systems Development Division, Information Technology Laboratory, WES, ERDC. Ms. Marion P. Alberts, GEED, assisted with data processing, and Mses. Donna B. Rowland and Corrie Spivey, GEED, assisted in preparation of the report. Mr. R. C. Correa, Energetic Materials Research and Testing Center, New Mexico Institute of Mining and Technology, supervised explosive handling and mine reentry safety inspection.

A seismic refraction survey was performed on the surface above the test chambers at the Linchburg Mine by personnel from Test Division, Counter Proliferation Directorate, Defense Threat Reduction Agency (DTRA). Mr. J. A. Leverette, DTRA, also measured surface seismic signals during the test. The seismic investigations were funded in part by DTRA and were performed under the direct supervision of Dr. R. E. Reinke, DTRA.

The work reported herein was performed under the supervision of Mr. Andrew E. Jackson, Acting Chief, GEED, and Dr. Michael J. O'Connor, Acting Director, SL.

At the time of publication of this report, Dr. Lewis E. Link was acting Director of ERDC, and COL Robin R. Cababa, EN, was Commander. 


\section{Introduction}

\section{Background}

\section{Requirements}

The Singapore Ground Shock Test was conducted at the Linchburg Mine near Magdalena, NM, where WES performed previous experiments related to Underground Ammunition Storage Technologies (UAST) research. The UAST program was designed to (a) develop more accurate predictions of the hazard distances (Quantity-Distance, or QD) for inhabited buildings associated with underground magazines, and (b) investigate specific design features that could significantly reduce the QDs. The goal was to technically demonstrate that the QDs for underground magazines could be reduced to 10 percent or less of those required for above-ground magazines.

The term "underground magazine" refers to an ammunition storage facility that is excavated as a system of access tunnels and storage chambers in rock. The explosion hazards of concern normally include the airblast, ejected debris, and ground shock produced by an accidental explosion of the stored ammunition.

In 1995, the Ministry of Defense of the Republic of Singapore (SN/MOD) announced that the use of underground magazines was being considered as a means of storing defense ammunition reserves in Singapore. Since there are essentially no large hills or mountains in Singapore, an alternative concept was being considered, i.e., to place the storage chambers in rock deep below the surface, with access tunnels that ramp down from the surface.

With this concept, the length and configuration of the access tunnels would be such that the airblast and debris hazards would be greatly reduced (assuming the storage chambers are deep enough to preclude breaching to the surface). However, with the severe limitations on available real estate in Singapore, it is probable that the allowable hazard area on the surface will be very small-perhaps even non-existent. With the airblast and debris hazards essentially eliminated, the threat of primary concern becomes the ground shock and resulting surface motions generated by an accidental explosion. 


\section{Proposed R\&D program}

The U.S. Army Engineer Waterways Experiment Station (WES) was the lead U.S. technical agency for the UAST program. At the recommendation of the U.S. Department of Defense Explosives Safety Board (DDESB), SN/MOD representatives proposed to WES the possibility of a cooperative US/SN research program to investigate further the ground shock hazards associated with deep underground magazines.

WES responded in late 1995 with a rough, preliminary proposal to SN/MOD for a joint U.S./Singapore R\&D program (Davis 1995). The proposed program was structured around three principal tasks:

Task 1: Development of Improved Predictions of Ground Shock from Explosions in Underground Chambers

Task 2: Investigation of Methods for Mitigating Ground Shock from Explosions in Underground Chambers

Task 3: Revision of Ground Shock Hazard Criteria for Inhabited

\section{Buildings}

Task 1 was funded (with some modifications) by SN/MOD and provided the basis for the study described in this report.

\section{Development of the 1996 Singapore ground shock test}

During the time the preliminary proposal was being reviewed and developed, WES was scheduled to complete a final series of large-scale explosive tests for the UAST program. The tests were conducted at WES's underground test facility in the Linchburg Mine near Magdalena, NM. While a number of measurements were made of ground shock produced by the UAST experiments, the primary emphasis was on the airblast, debris, and thermal effects generated within the tunnel/chamber system. Those UAST tests that did involve ground shock measurements were also highly idealized, in that the explosive charges were constructed of near solid explosive, and were aligned along the central, horizontal axis of the chambers. The close-in ground shock was measured in several directions to determine if asymmetries in shock attenuation rates would occur due to the horizontal structure of the local rock geology.

The final UAST test was designated as the UAST Validation Test and was designed to validate the blast effects control and prediction methodologies developed under the program. The Validation Test involved the detonation of $1955 \mathrm{~kg}$ of explosives in a chamber volume of $70 \mathrm{~m}^{3}$, located approximately $115 \mathrm{~m}$ below the surface in a limestone rock geology.

The UAST Validation Test offered an excellent opportunity to obtain information that would directly support the underground magazine problem for Singapore, i.e., the magnitude and characteristics of ground shock and the resulting surface motions above a detonation in a deep storage chamber in hard 
rock. The Validation Test also involved a much more realistic detonation, with the charge located on the chamber floor, and was comprised of a large number of heavy cased munitions. Consequently, an effort to obtain such data was planned as an "add-on" to the scheduled Validation Test. Funding from the SN/MOD to support this work was provided under a U.S. Army-administered Foreign Military Sales case.

The add-on effort included (a) drilling of a vertical, 115-m-long gage hole from the test chamber to the ground surface, (b) installation of ground shock gages (accelerometers) in the gage hole up to a height of $32 \mathrm{~m}$ above the chamber, (c) installation of an array of seismic motion gages on the ground surface above the test area, (d) recording and analysis of data obtained by the ground shock and seismic gages, and (e) documentation of the geologic profile along the vertical gage hole and the surface profile along the seismic gage array.

Unfortunately, the on-site contractor experienced severe problems in the initial efforts to drill the vertical gage hole upward from the test chamber. In early 1996, these problems continued until it became clear that continued efforts would cause an unacceptable delay in the performance of the Validation Test. Consequently, it was decided to discontinue the drilling and proceed with the Validation Test without the add-on instrumentation. Instead, a new test, designed specifically for the ground shock instrumentation objective, was scheduled to follow the UAST Validation Test. Named the 1996 Singapore Ground Shock Test, the new experiment would also allow selection of an explosive charge weight more suitable to the Singapore magazine concept. A charge weight of $696 \mathrm{~kg}$ was selected to provide a chamber loading density of $10 \mathrm{~kg} / \mathrm{m}^{3}$.

Following the completion of the Validation Test in April 1996, the drilling of the vertical gage hole was resumed and completed in May 1996. The required gages were emplaced, and the Singapore Ground Shock Test was conducted in June 1996. This report provides details of the test design, operations, and results.

\section{Objectives}

The primary objective of the Singapore Ground Shock Test was to document the ground shock and surface motions produced by a simulated accidental detonation of munitions in an underground storage chamber, at a nominal loading density of $10 \mathrm{~kg} / \mathrm{m}^{3}$. A secondary objective was to record the airblast levels produced in connected tunnels and beyond the tunnel portal.

\section{Test Site Location and Geology}

The underground test area was located within the Linchburg Mine in Socorro County, NM, in Section 7, Township 3S, Range 3W. The location is about $9.6 \mathrm{~km}$ southwest of the small town of Magdalena, NM. The Linchburg Mine consists of underground workings on four patented mining claims within the Magdalena Mining District of New Mexico. The mine was operated primarily for the recovery of lead and zinc, and was active until 1972 when, for economic reasons, it was closed. It is currently in a caretaker status. 
The Linchburg Mine is located on the north end of the Magdalena Uplift, a horst block tectonic feature within the Rio Grande Rift/Depression. The Magdalena Mountain Range, approximately $39-\mathrm{km}$ long and $16-\mathrm{km}$ wide, is the topographic expression of the Magdalena Uplift. Maximum relief within the range is approximately $1100 \mathrm{~m}$, and the maximum elevation is $3050 \mathrm{~m}$. The Linchburg Mine lies on the western slope of the Magdalena Range, at an elevation of $454 \mathrm{~m}$.

Rocks exposed in the region range in age from Precambrian to Quaternary. The majority of the exposures above the base of the Magdalena Range consist of Paleozoic marine sediments ranging in age from Pennsylvanian to Permian, with Tertiary intrusive and extrusive igneous rock. Most of the Linchburg Mine workings are located in the Mississippian Kelly Limestone, where large replacement bodies of sulfide ore developed adjacent to the major faults. This project was located in an interval of the Kelly Limestone lying between 215 and $275 \mathrm{~m}$ from the mine portal. This particular interval is known as the Upper Kelly Limestone, and, at the location of the test area, is $12-\mathrm{m}$ to $15-\mathrm{m}$ thick.

Core samples of the Upper Kelly Limestone were taken during the FY 94 test program, and 13 samples were selected for laboratory testing. Laboratory test results on the cores (Martin 1994) show that the Upper Kelly formation is a coarse-grained, dense limestone, with a mineralogy that is predominantly calcite and quartz. The average dry bulk density is $2.69 \mathrm{~g} / \mathrm{cc}$. Laboratory ultrasonic velocity determinations showed an average $P$-wave velocity of $5400 \mathrm{~m} / \mathrm{sec}( \pm 300$ $\mathrm{m} / \mathrm{sec})$, and an average S-wave velocity of $3200 \mathrm{~m} / \mathrm{sec}( \pm 300 \mathrm{~m} / \mathrm{sec})$. The average compressive strength was $100 \mathrm{MPa}( \pm 30 \mathrm{MPa})$.

Figure 1 is a plan view of the Linchburg Mine in the vicinity of the test area. Two test drifts and seven test chambers were excavated as part of the 1994 UAST program. Two of these rooms, Chambers 1 and $2 \mathrm{~m}$ were still structurally sound after the 1994 test program, and were modified for the FY96 test program.

An approximate geologic profile of the media penetrated by the vertical gage hole drilled from Chamber 2 is shown in Figure 2. Rock cores were obtained for the lower $34 \mathrm{~m}$ of the gage hole. Because of the original time constraints on completion of the drilling, a roller bit was used rather than a slower core barrel bit above $34 \mathrm{~m}$. The geologic profile was developed from the cores, chip samples (produced by the roller bit), and notations made during the drilling process. Briefly, the profile shows limestone to a height of about $24 \mathrm{~m}$ above the chamber, overlain by a $9 \mathrm{~m}$ layer of shale, then $12 \mathrm{~m}$ of limestone with intermittent beds of marine sediments. The upper $65 \mathrm{~m}$ was limestone, with intrusive quartz near the ground surface. A refraction seismic survey showed seismic velocities at 12 to $18 \mathrm{~m}$ below ground surface to be less than $1200 \mathrm{~m} / \mathrm{sec}$, indicating a highly weathered or fractured material (see Chapter 3, Surface Motions). Original plans . for this effort had called for an uphole seismic survey and borehole camera survey. However, drilling difficulties, and consequent placement of steel casing and a 51-mm-diameter PVC pipe in the upper portions of the borehole to maintain hole integrity, precluded these measures. 


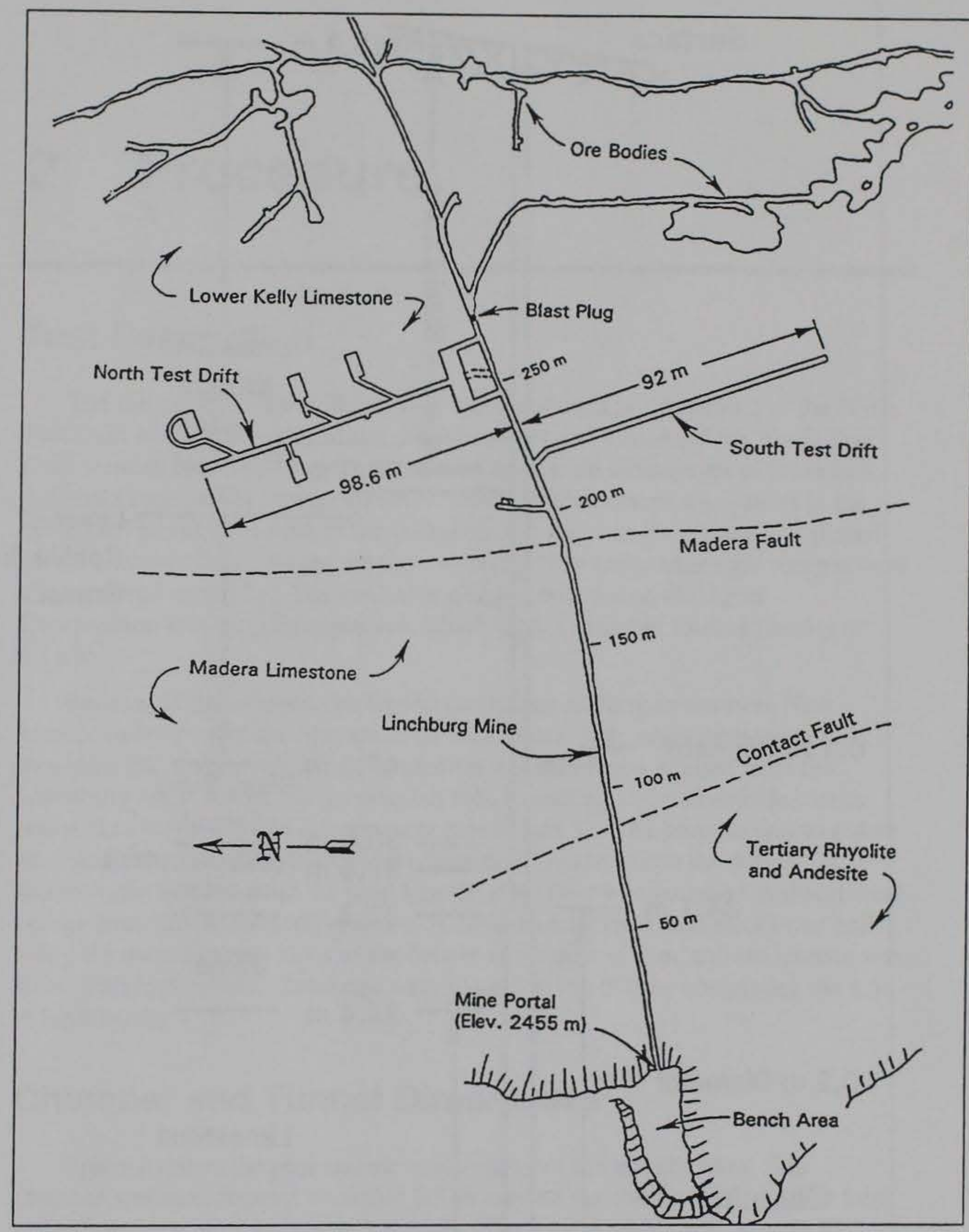

Figure 1. Layout of test drifts and chambers in Linchburg Mine for $1 / 3$-scale underground magazine blast effects tests 


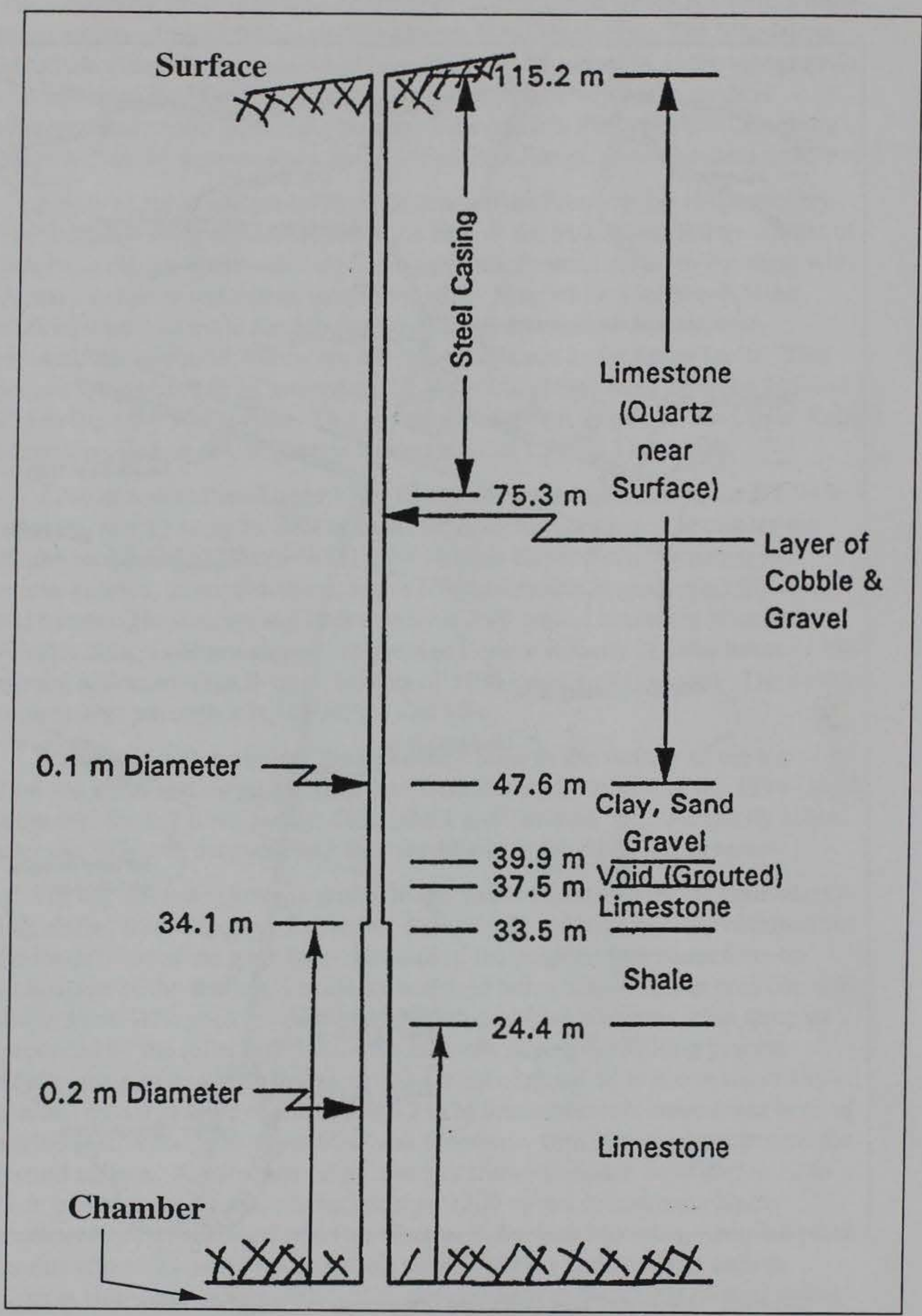

Figure 2. Approximate geologic profile for vertical gage hole above Chamber 2 


\section{Procedure}

\section{Test Description}

The Singapore Ground Shock Test was conducted in Chamber 2 of the North Test Drift in the Linchburg Mine. The chambers and tunnels of the North Test Drift were all constructed as idealized, one-third scale simulations of those in a full-scale ammunition storage facility. The explosive charge was placed in the horizontal geometric center of the chamber. For this test, the charge was placed on the chamber floor, in contrast to most of the 1994 tests, where the charges were also centered vertically. The explosive charge consisted of $696 \mathrm{~kg}$ of Composition B (Comp B) explosive, which gave a chamber loading density of $10 \mathrm{~g} / \mathrm{m}^{3}$.

Because of the extreme fire hazard conditions existing in southern New Mexico at the time of the Singapore Ground Shock Test, steps were taken to minimize the chance of burning detonation products being emitted from the Linchburg Mine portal. To accomplish this, a sandbag and rock-rubble barrier was placed just inside the test chamber (see Figure 3 ). The purpose was to reduce the initial surge of blast pressure and detonation products into the tunnel. In addition, the dispersion of the sand into the blast flow was intended to absorb heat energy from the detonation products. A sandbag wall (two bags thick) was built along the three exposed sides of the barrier to a height of $1 \mathrm{~m}$, and the interior was filled with rock rubble. Sandbags were placed on top of this, completing the 1.5m high barrier.

\section{Chamber and Tunnel Dimensions}

Figure 4 shows the plan and elevation views of the test chamber. The chamber was an elongated trapezoid $8.5-\mathrm{m}$ long on the shortest side, 10.8-m long on the long side, 4-m wide, and 2-m high. The total chamber volume was 77.23 . The sandbag and rock rubble barrier was also trapezoidal in shape and occupied a volume of $7 \mathrm{~m}^{3}$, yielding a net chamber volume of $70.2 \mathrm{~m}^{3}$. The access tunnel leading into Chamber 2 from the North Test Drift was $1.35-\mathrm{m}$ wide and $1.5-\mathrm{m}$ high, and consisted of two sections, one 9-m long leaving the North Test Drift at a $45^{\circ}$ angle, and one $6.7-\mathrm{m}$ long leading into the chamber itself. 


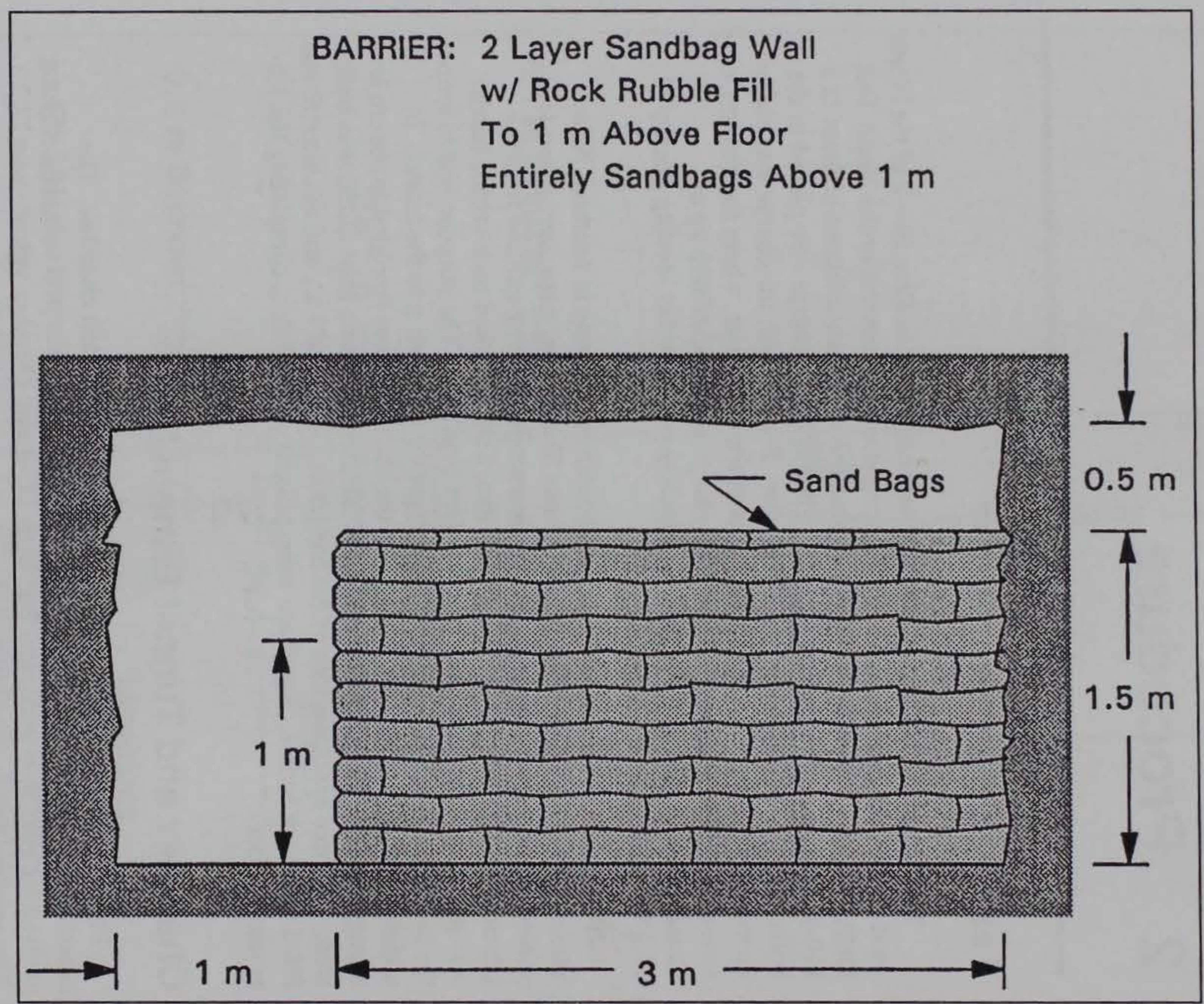

Figure 3. Front view of sandbag and rock rubble barrier inside the entrance to Chamber 2 


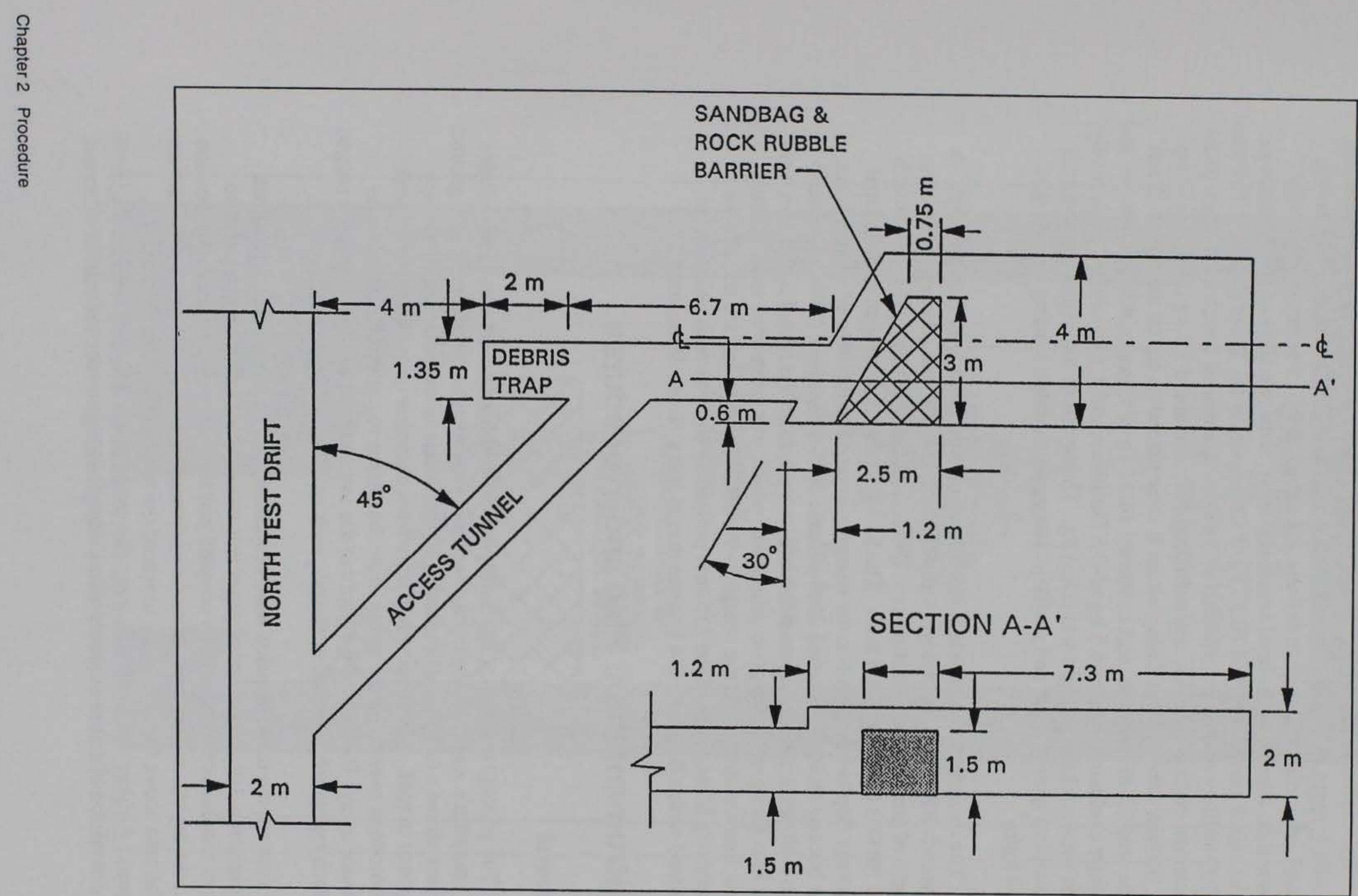

Figure 4. Configuration and dimensions of test chamber (Chamber 2) 


\section{Explosive Charge}

The explosive charge for the Singapore Ground Shock Test was constructed of M-15 mines, $155-\mathrm{mm}$ projectiles, and cast Composition B cubes to simulate actual ammunition storage materials. A total of $28 \mathrm{M}-15$ mines were closely stacked on edge in a two-level horizontal array, with two rows of seven mines per level. Each mine contained $10.34 \mathrm{~kg}$ of Composition B. Three pallets of $155-\mathrm{mm}$ M107 artillery rounds were placed at the sides and rear of the charge. Each pallet contained eight projectiles, and each projectile contained $7.1 \mathrm{~kg}$ of Composition B. Sixteen cubes of cast Composition B were placed on top of the mines. Each cube was $0.2 \mathrm{~m}$ on a side, and contained $14.32 \mathrm{~kg}$ of Composition B. Initiator and booster explosives totaled $6.6 \mathrm{~kg}$ of C- 6 Detasheet and $1.1 \mathrm{~kg}$ of C-4, respectively. The total explosive weight was $696.6 \mathrm{~kg}$. The layout of the explosive charge is shown in Figure 5 (plan and profile). The exact chamber loading density was $9.92 \mathrm{~kg} / \mathrm{m}^{3}$.

The explosive charge was initiated with a Reynolds FS-42 firing system. A Reynolds RP-83 electric bridge wire (EBW) detonator was attached to a $300-\mathrm{m}$ length of non-electric initiation cord (Nonel). Each test was dual-initiated with two EBW's and two Nonel lines. The M-15 mines were arrayed in horizontal columns (top to base). A booster charge was taped to the base of each column. The booster charges consisted of two sheets of C- 6 detasheet (254-mm square) with a Nonel detonator between them. The leads from the Nonel detonators were tied into a ring main (22-grain primacord) which was connected to two Nonel trunk lines running from the charge to the EBW initiator located outside the Linchburg Mine. Half of the $155-\mathrm{mm}$ projectiles (four in each pallet) were initiated with a $0.114-\mathrm{kg} \mathrm{C}-4$ booster charge and a Nonel detonator.

\section{Instrumentation: Plan and Procedures}

\section{General}

The primary purpose of the Singapore Ground Shock Test was to investigate the magnitude and characteristics of seismic-type motions produced on the ground surface above a (simulated) explosion of munitions in an underground storage chamber in rock. Ideally, it would have been desirable to record ground shock and motions over the entire range, from the source to surface locations some distance away. Because of the depth of the test chamber at Magdalena, the rugged surface topography, and other factors, such an effort was not feasible.

Instead, the measurements were concentrated at the two ends of the shock transmission path. An array of gages was installed above the test chamber to record the level of shock energy coupled into the rock surrounding the detonation (i.e., the input), and an array of surface seismic gages was installed on the surface in the area above the detonation to record the resulting surface motions (i.e., output). Airblast measurements were also made in the tunnel system leading from the detonation chamber to ensure that a complete, high-order detonation occurred. 


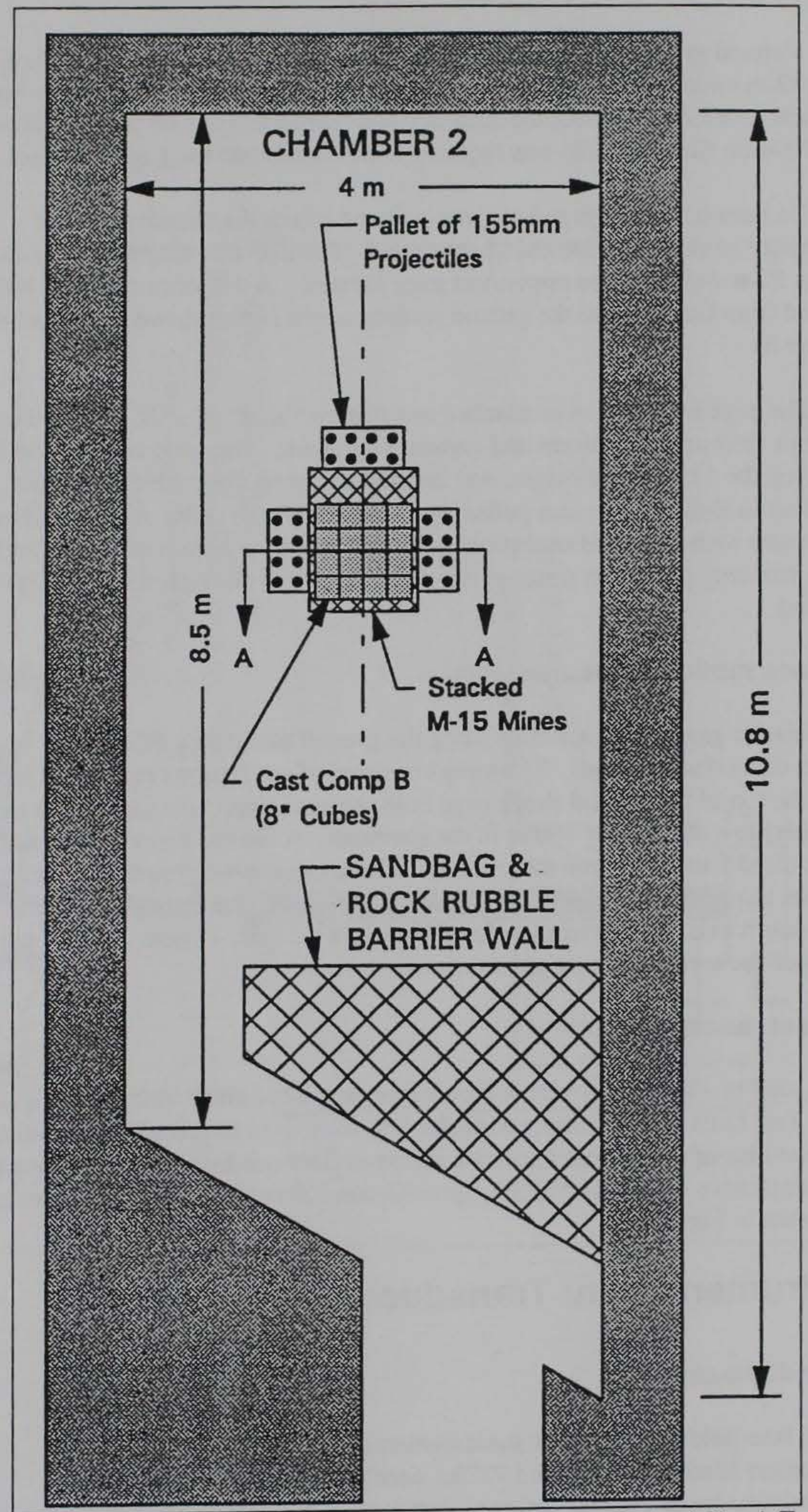

Figure 5. Explosive charge design for Singapore Ground Shock Test 


\section{Ground shock measurements}

Vertical ground shock accelerations were measured at distances of 4, 8, 15, and $32 \mathrm{~m}$ directly above the center of the test chamber. Two gages were installed at each location to confirm the accuracy and reproducibility of the measurements. A 200-mm-diameter hole was required to accommodate the gage canisters.

To ensure that the gage hole was centered above the chamber, it was necessary to drill from the chamber upward. The 200-mm-diameter hole extended to the 32-m height of the uppermost gage location. A $100-\mathrm{mm}$-diameter hole was drilled from that point to the ground surface, some $115 \mathrm{~m}$ above the chamber (see Figure 6).

The gage canisters were attached to a narrow "sled" of PVC pipe to keep them in their proper position and vertical alignment. The gage cables were first lifted up the 115-m hole height, and the sled was then assembled in the test chamber in 2-m sections and pulled up into the 200-mm hole. After checking to make sure each gage was operational, the bottom of the hole was sealed, and a rock-matching grout was pumped into the hole in lifts through the PVC pipes of the sled.

\section{Surface motion measurements}

Seismic gages were installed along the ground surface by FC/DTRA, to record the surface motions. The array consisted of six stations ranging in location from the top of the ground shock gage hole (approximately directly above the chamber) to a distance of $154 \mathrm{~m}$ to the southeast. A remote array of four stations was located 1 to $2 \mathrm{~km}$ from the test area. Three gages were installed at each location to provide triaxial measurements, i.e., vertical, horizontal, along the north-south axis, and horizontal along the east-west axis. Figure 7 shows the layout of the surface motion gage stations.

\section{Airblast measurements}

A total of 15 side-on overpressure gages, emplaced flush with the floor of the North Test Drift and Linchburg Mine tunnel, were used to record the pressuretime histories of the airblast shock wave and as flow produced by the detonation of the explosive charge for the Singapore Ground Shock Test. The gage locations are shown in Figure 8.

\section{Instrumentation: Transducers}

\section{Ground shock gages}

All free-field ground shock measurements were made with Endevco Corporation Model 2262CA and $7270 \mathrm{~A}$ accelerometers. Both models are peizoresistive types with the active elements used in a bridge configuration. The 


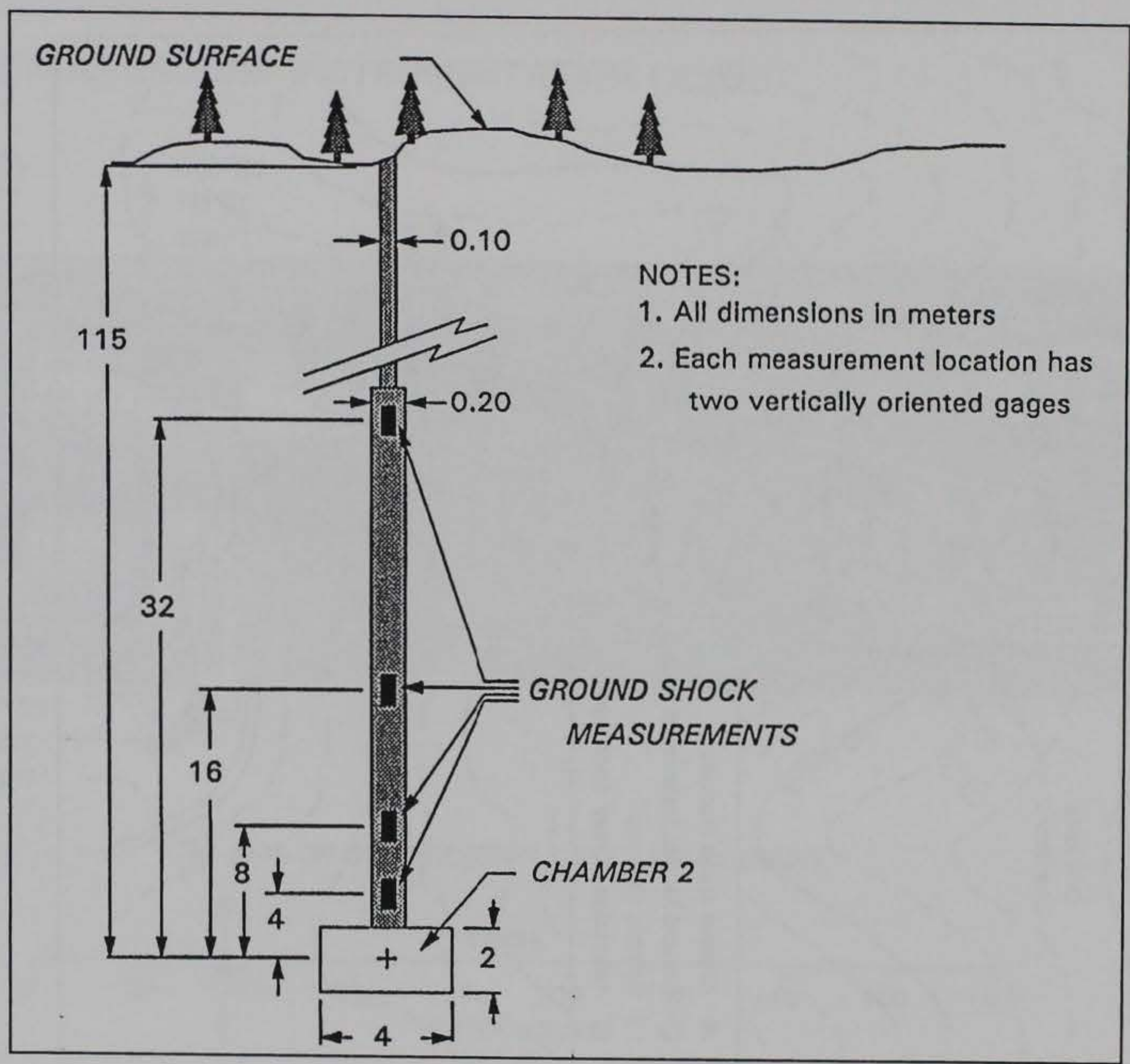

Figure 6. Ground shock measurements locations in vertical gage hole for Singapore Ground Shock Test 


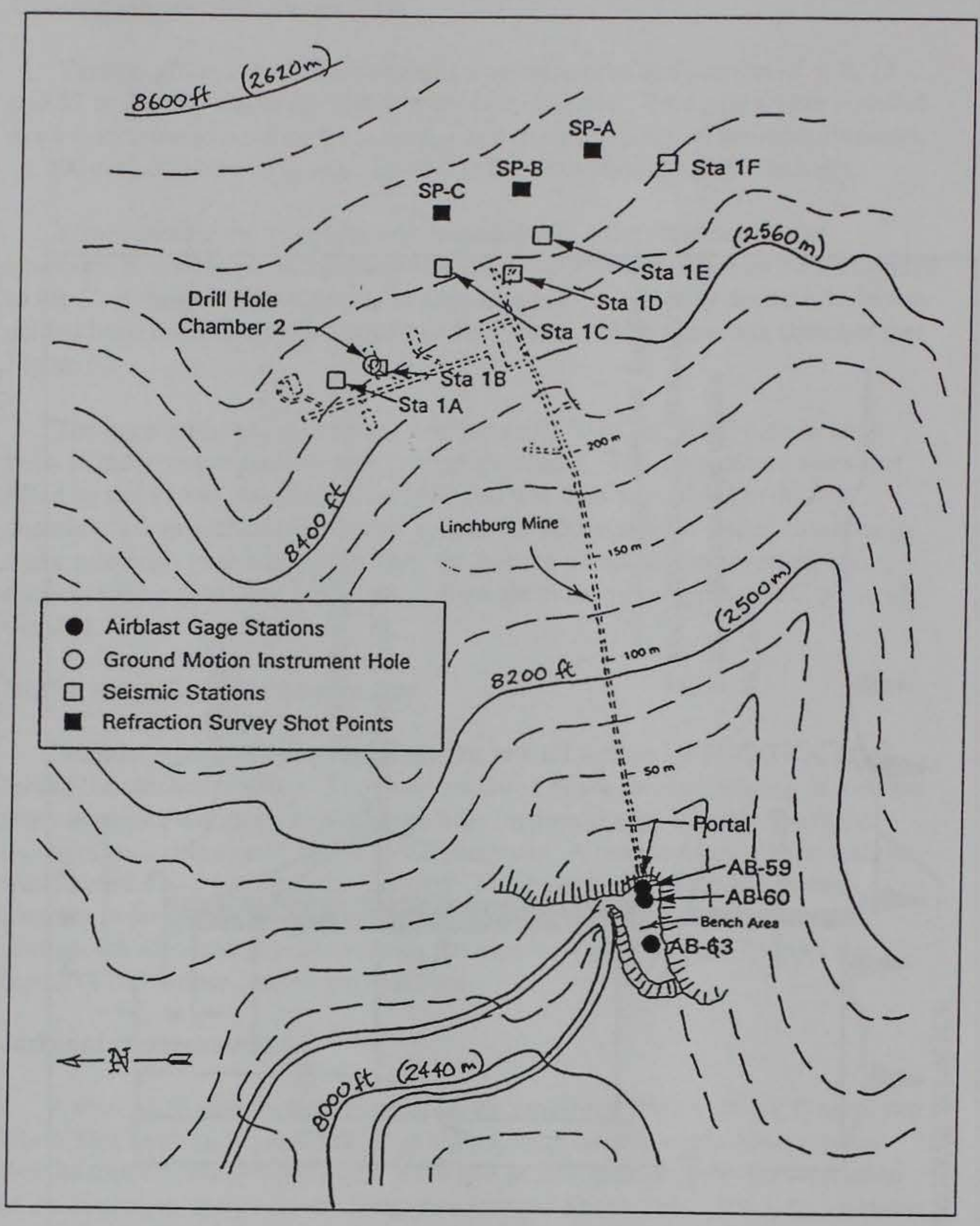

Figure 7. Seismic sensor and shot point layout on overburden surface above the Linchburg Mine, Singapore Ground Shock Test 


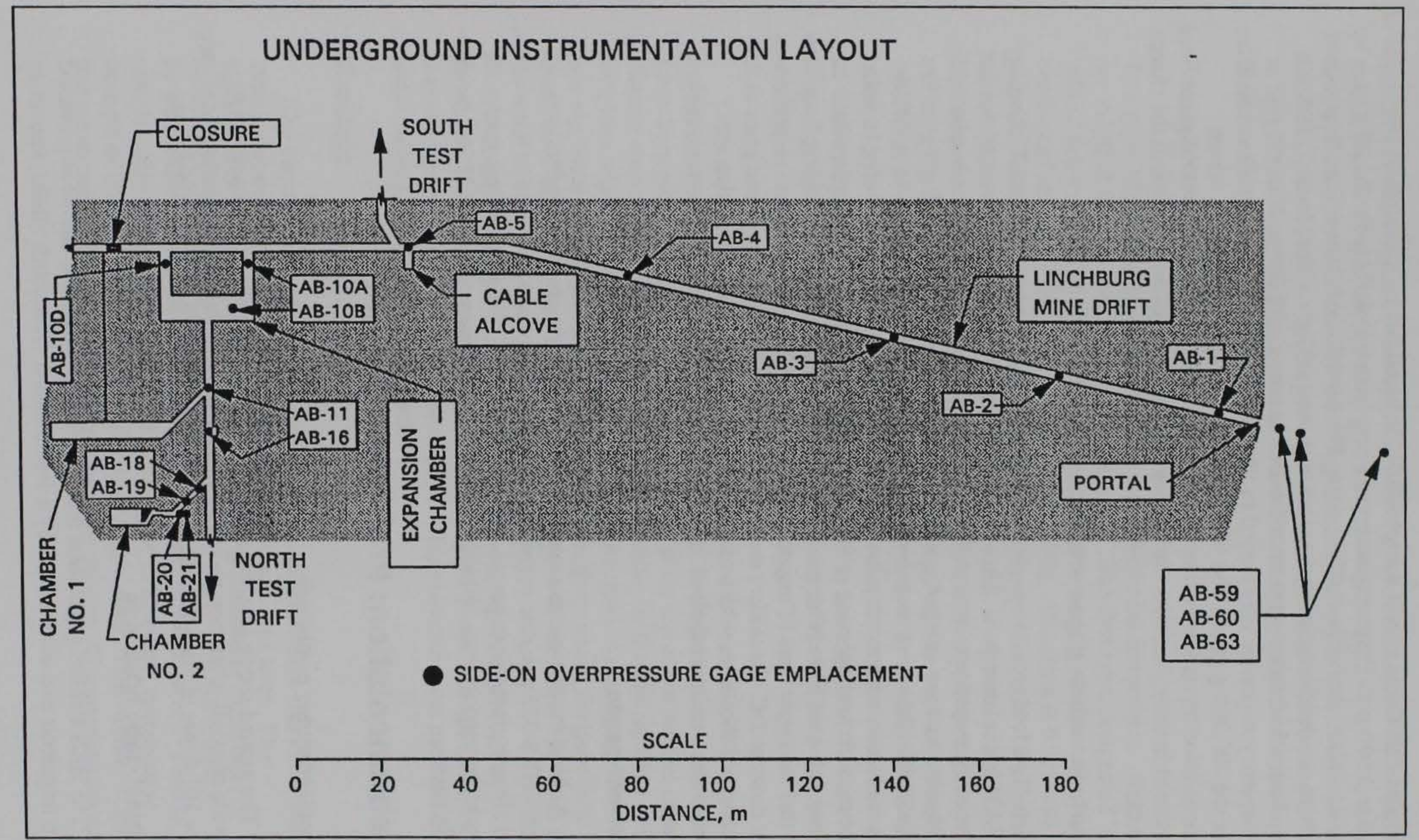

Figure 8. Airblast gage layout for Singapore Ground Shock Test 
Model $2262 \mathrm{CA}$ is a fluid-damped $(0.707$ critical) device manufactured in ranges of 25 to 2,000 g's. Frequency responses vary from 0 to $650 \mathrm{~Hz}$ for the 25 -g gage up to 0 to $3,000 \mathrm{~Hz}$ for the 2,000-g gage. The Model 2262CA was used in positions where acceleration was expected up to about $1,000 \mathrm{~g}$ 's. The Model $7270 \mathrm{~A}$ is a miniature, undamped gage manufactured in ranges of 2,000 to $200,000 \mathrm{~g}$ 's. Frequency responses vary from 0 to $10 \mathrm{kHz}$ for the 2,000 -g gage to 0 to $150 \mathrm{kHz}$ for the 200,000-g gage. The Model $7270 \mathrm{~A}$ was used at positions where acceleration levels were expected to be above $1,000 \mathrm{~g}$ 's. All free-field gages were oriented radially, i.e., with the sensing axis of the gages aimed towards the charge center.

\section{Surface motion gages and recording system}

All surface ground motion measurements were made with Terra Technology SSA312 accelerometers. These transducers are servo accelerometers with a flat frequency response from 0 to $50 \mathrm{~Hz}$. The sensitivity of these gages is adjustable and was set to one volt per g, which gives a peak-to-peak range of $\pm 5 \mathrm{~g}$ 's. The acceleration data were recorded on digital Refraction Technology 71 A-07 36channel units, with a dynamic range of 24-bits and an input range of \pm 10 volts. The recorder was operated at 500 samples per second. These recorders have an initial anti-alias filter, which was set at about $4 / 5$ of the Nyquist folding frequency, so that the upper limit of response was about $200 \mathrm{~Hz}$ and the system response was flat down to DC. Recorders were set to turn on a coupled of minutes prior to the anticipated shot time, with a total record length of 5 minutes. Timing was provided by an internal clock, which was corrected to GPS satellite time each second.

\section{Airblast gages}

Airblast measurements were made using Kulite Semiconductor Products Model HKS-375 pressure gages. These units are piezoresistive bridge transducers, and are manufactured in ranges of 3.45 to $206 \mathrm{MPa}$. The natural frequencies are very high, ranging from $350 \mathrm{kHz}$ for the $3.45-\mathrm{MPa}$ gage up to $725 \mathrm{~Hz}$ for the 206 $\mathrm{MPa}$ gage.

\section{Instrumentation: Protection Systems}

\section{Accelerometer canisters}

The ground shock accelerometers were mounted in aluminum canisters to provide physical protection and solid mounting platforms. The cylindrical canisters were $101.6 \mathrm{~mm}$ in diameter and $76.2 \mathrm{~mm}$ long with a $19-\mathrm{mm}$ wall thickness.

\section{Airblast gage housings}

The HKS airblast gages were mounted in steel housings, and were protected from fragments and other debris by a debris shield. The debris shield, known as 
the "8-hole debris shield," consists of two steel disks; one contains the airblast gage threaded mount, and the other provides a ported cavity. The porting system consists of eight small holes drilled though the disk. Details of both disks are shown in Figure 9. The airblast porting holes are $1.4 \mathrm{~mm}$ in diameter and $4.74 \mathrm{~mm}$ in length. Previous test data indicates that this shield should allow for airblast rise times on the order of 200 microseconds.

\section{Cable and cable protection}

Two types of signal cables were used for instrumentation connections. Both types are shielded, twisted-pair instrumentation cables. The first type, designated "small cable," is a 4-conductor shielded cable $3.12 \mathrm{~mm}$ in diameter. Individual conductors are \#28 AWG, with polyethylene jackets. Shielding is $0.025-\mathrm{mm}$ polyester/aluminum tape providing $100 \%$ coverage, with four \#28 AWG drain wires. The outer jacket is PVC. Conductor resistance is $22.9 \mathrm{ohms} / 100 \mathrm{~m}$. Capacitances are $75 \mathrm{pF} / \mathrm{m}$ (conductor-to-conductor) and $141 \mathrm{pF} / \mathrm{m}$ (conductor-toshield). The second cable type, designated as "large" cable, is a 4-conductor shielded cable $6.45 \mathrm{~mm}$ in diameter. Individual conductors are \#22 AWG, with polyethylene jackets. Shielding is provided by \#34 AWG copper wire braid giving $90 \%$ coverage. The outer jacket is PVC. Conductor resistance is $4.5 \mathrm{ohms} / 100 \mathrm{~m}$. Capacitances are $65 \mathrm{pF} / \mathrm{m}$ (conductor-to-conductor) and $114 \mathrm{pF} / \mathrm{m}$ (conductor-toshield).

Large cable was used for the main cable runs, which extended from the instrumentation recording van to two junction box (J-box) locations; one inside the Linchburg mine (for airblast gages) and another at the top of the vertical gage hole, directly above the test chamber. Gage-to-J-box cable for the underground airblast locations was the small cable. Uphole cable for the ground shock accelerometers was the small cable to a point $34 \mathrm{~m}$ above the chamber (where the gage hole diameter reduced from $0.2 \mathrm{~m}$ to $0.1 \mathrm{~m}$ ), then, a splice to the larger cable was made.

At all locations where large stresses, rock fracturing, or high velocity fragments was a potential problem, the small cable was run through $6.35-\mathrm{mm}$ diameter stainless steel tubing for protection. This protection was used for all the small cabling in the vertical gage hole.

\section{Grouting}

The vertical gage hole for the ground shock measurements was filled with the same grout developed for and used on the 1994 Magdalena tests. The requirements for the grout design were, in order of decreasing importance: pumpability, density $\left(\operatorname{target}=2646 \mathrm{~kg} / \mathrm{m}^{3}\right)$, compressive strength (target $>$ $69 \mathrm{MPa}$ ), and P-wave velocity (target $=4570 \mathrm{~m} / \mathrm{sec}$ to $5490 \mathrm{~m} / \mathrm{sec}$ ). Tests of grout samples after the 1994 series showed a density of $2522 \mathrm{~kg} / \mathrm{m}^{3}$, compressive strength of $26.6 \mathrm{MPa}$, and P-wave velocity of $3129 \mathrm{~m} / \mathrm{sec}$. Pumpability of this mix was good, and the density was close to the target density. Compressive strengths 


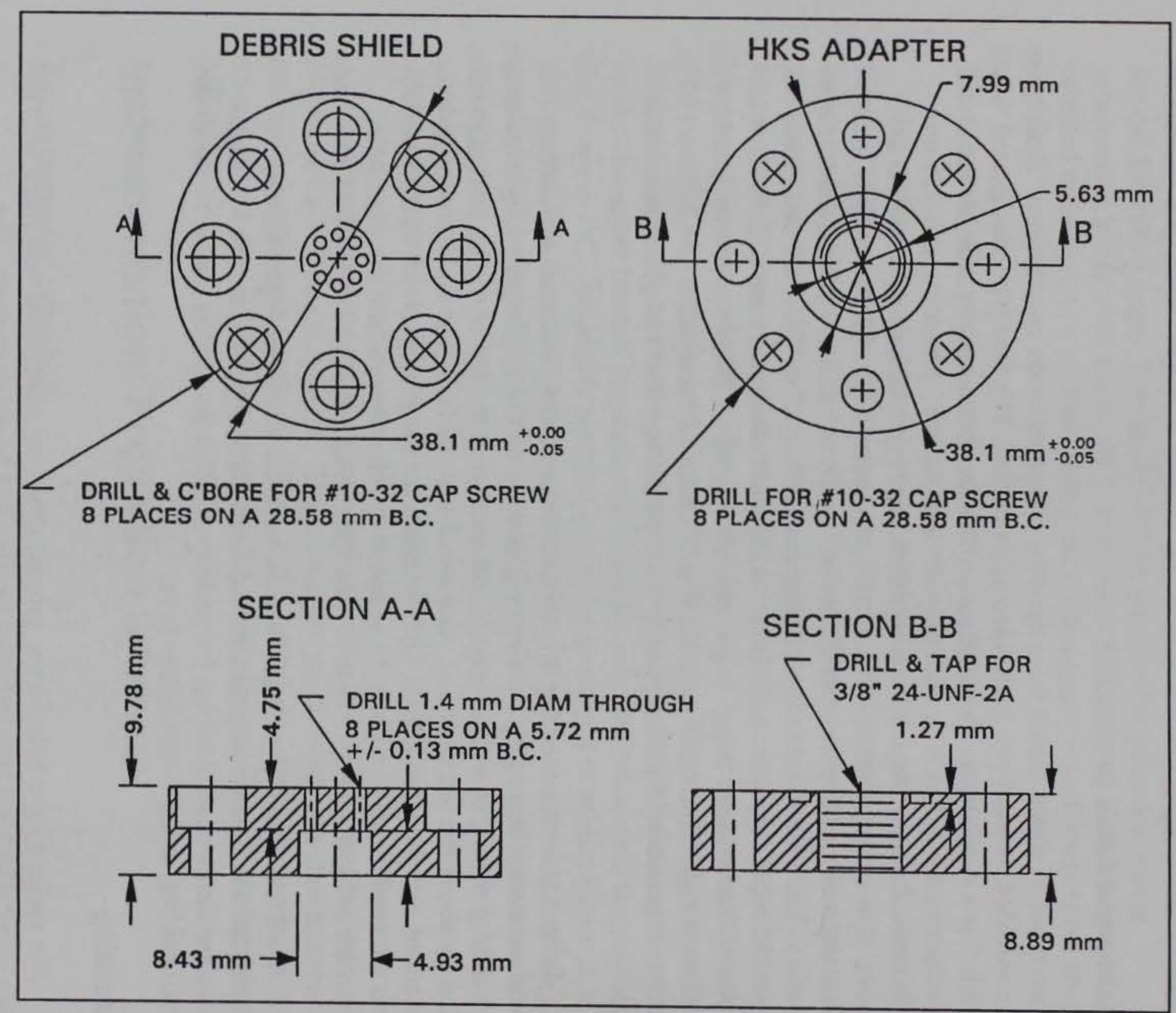

Figure 9. Airblast gage debris shield 
and $\mathrm{P}$-wave velocities were less that the target values, averaging 39 percent and 68 percent of the target values, respectively. The grout sample properties are given in Table 1.

\section{Instrumentation: Data Recording}

\section{Recording system}

Data processing and recording equipment was housed in an instrumentation trailer located about $200 \mathrm{~m}$ north of the Linchburg Mine portal. All electronic data were processed through WES Model 103-D differential amplifier/signal conditioning systems. Shunt resistor calibration was applied to each channel immediately prior to the test. Data signals were recorded on Pacific Model 9830 transient data recorders. These units utilize 14 memory segments, each capable of storing 8192 data points. Sample rates can be programmed individually for each memory segment. Ground shock data were recorded at a rate of 4 microseconds per sample for all 14-memory segments, giving a total recording time of 458 milliseconds. Airblast data sampling used individually programmed rates for each memory segment. The first six segments were sampled at four microseconds per sample. The next eight segments were sampled at decreasing rates of $8,16,32,64$, $128,256,512$, and 1024 microseconds per sample, respectively, to give a total recording time of 16.9 seconds.

\section{Predictions for gage ranging}

Airblast gage ranging for the Singapore Ground Shock Test was based on predictions computed with BLASTX (Version 3.5) computer code. BLASTX 3.5 contains recent modifications for predicting the airblast effects from detonations of large explosive charges in small rooms, analogous to underground storage magazines with moderate to large chamber loading densities.

Ground shock predictions for the Singapore Ground Shock Test were made using empirical methods drawn from the 1994 test program. Motion data from the 1994 tests were noted to be very nearly independent of the explosive loading density, expressed in terms of $\mathrm{kg} / \mathrm{m}^{3}$. Instead, motions were noted to scale with the cube root of the charge weight. 
Table 1.

Results of Grout Sample Properties Tests

\begin{tabular}{|c|c|c|c|c|c|c|c|}
\hline $\begin{array}{c}\text { Date } \\
\text { Cast } \\
\text { (June 96) }\end{array}$ & $\begin{array}{c}\text { Batch } \\
\text { No. }\end{array}$ & $\begin{array}{c}\text { Specimen } \\
\text { No. }\end{array}$ & $\begin{array}{c}\text { Age } \\
\text { (days) }\end{array}$ & $\begin{array}{c}\text { Sonic } \\
\text { Pulse } \\
\text { Velocity } \\
\text { (m/sec) }\end{array}$ & $\begin{array}{c}\text { Dynamic } \\
\text { Modulus } \\
(\mathrm{GPa})\end{array}$ & $\begin{array}{c}\text { Unconfined } \\
\text { Density } \\
\left(\mathrm{Mg} / \mathrm{m}^{3} \text { ) }\right.\end{array}$ & $\begin{array}{c}\text { Sompressive } \\
\text { Strength } \\
\text { (MPa) }\end{array}$ \\
\hline 10 & 1 & 1 & 8 & $3,464.6$ & 22.08 & 2.65 & 38.69 \\
\hline 10 & 1 & 2 & 8 & $3,441.5$ & 21.50 & 2.65 & 38.21 \\
\hline 10 & 1 & 3 & & & & & 37.76 \\
\hline 11 & 2 & 4 & 7 & $3,433.2$ & 22.10 & 2.72 & 34.34 \\
\hline 11 & 2 & 5 & 7 & $3,425.3$ & 22.72 & 2.72 & \\
\hline 11 & 2 & 6 & & & & & 35.79 \\
\hline 11 & 4 & 7 & 7 & $3,427.4$ & 21.63 & 2.70 & 36.48 \\
\hline 11 & 4 & 8 & 7 & $3,395.1$ & 21.73 & 2.71 & \\
\hline 11 & 4 & 9 & & & & & 34.10 \\
\hline 12 & 5 & 10 & 6 & $3,372.6$ & 20.48 & 2.65 & 33.41 \\
\hline 12 & 5 & 11 & 6 & $3,387.5$ & 21.30 & 2.65 & \\
\hline 12 & 5 & 12 & & & & & 30.69 \\
\hline 12 & 7 & 13 & 6 & $3,358.8$ & 22.34 & 2.69 & \\
\hline 12 & 7 & 14 & 6 & $3,418.3$ & 20.59 & 2.68 & 37.21 \\
\hline 12 & 7 & 15 & & & & & \\
\hline
\end{tabular}




\section{Results and Discussion}

\section{General}

The Singapore Ground Shock Test was detonated at 1400 hours on 18 June 1996. At shot time, all airblast and ground shock gage channels were active (although one accelerometer, Gage 332B, was noisy and unstable). All recording equipment operated as programmed. A high-order detonation was achieved, and substantial dust and very small debris exited the tunnel portal. No flame was evident at the portal.

A crater measuring approximately $0.5-\mathrm{m}$ deep and $4 \mathrm{~m}$ in diameter was formed in the floor of the test chamber, beneath the charge position (Figure 10). No other damage to the chamber or access tunnel was noted, other than small chips in the rock surfaces from fragment impacts. The sandbag/rock rubble barrier at the front of the chamber was completely blown away. Most of the debris was deposited in the debris trap in front of the chamber entrance.

\section{Free-Field Ground Shock Measurements}

\section{Instrument performance}

Five of the eight free-field accelerometers installed yielded excellent data. Two gages that failed to provide good data were in the uppermost canister, at a range of $32 \mathrm{~m}$ from the chamber center. One of these (Gage 332B), as mentioned above, had been producing noisy and unstable outputs prior to the test, and its failure can be attributed to gage or cable damage. The other (Gage 332A) produced a freely oscillating signal at about $150 \mathrm{~Hz}$, which was almost certainly due to failure of the grout to completely envelope the canister, allowing it to vibrate, or "rattle," in the borehole. This problem was not unexpected, due to problems encountered in pumping the grout to such a height through the smalldiameter PVC pipe.

The third gage, which failed to produce good data, was Gage 308A. This gage yielded a high-quality signal which showed all the timing and pulse characteristics of Gage 308B; its amplitude, however, was too high by a factor of 


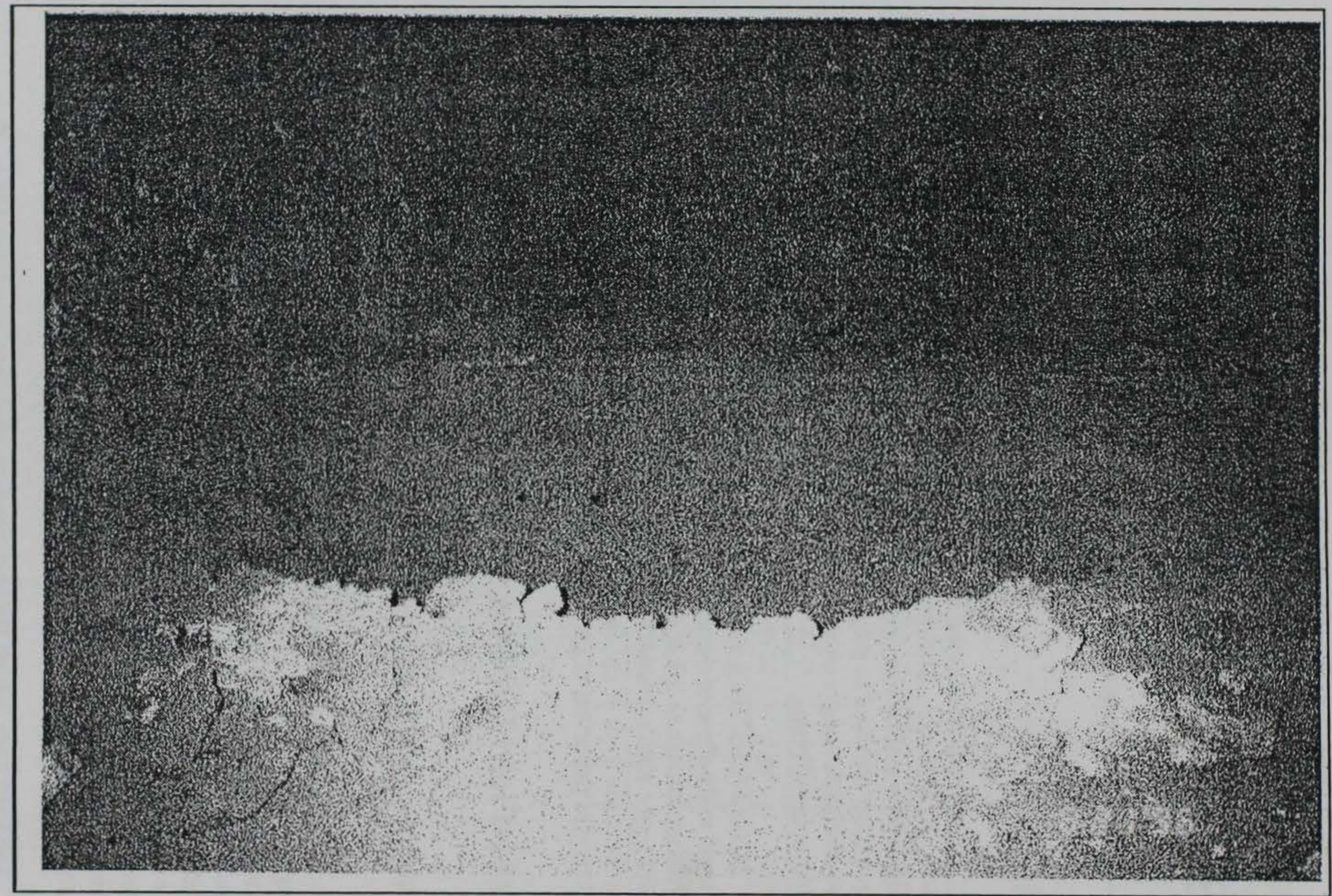

Figure 10. Crater in the floor of Chamber 2 produced by the explosive charge detonated for the Singapore Ground Shock Test 
6 to 7. Extensive checks of the calibration records, calibration resistor, amplifier response, amplifier gain, and digital recorder response failed to provide any satisfactory explanation of the problem. It is concluded that, for this gage, an error occurred in calibration or signal amplitude that defies identification and correction.

\section{Shock arrival times}

Data from the free-field ground shock measurements are summarized in Table 2. Time histories, including first and second integrals, are presented to a time of $40 \mathrm{msec}$ in Appendix A. Initial arrival times for the ground shock are plotted versus distance in Figure 11. Propagation velocities were $5,738 \mathrm{msec}$ for the 4 - to 8- $\mathrm{m}$ interval above the chamber, $4,050 \mathrm{msec}$ for the 8- to $16-\mathrm{m}$ interval, and 3,751 msec for the 16- to 32-m interval. For Test 5 in the 1994 series, which was a test of $14.6 \mathrm{~kg} / \mathrm{m} 3$ loading density in Chamber 4 (located about $27 \mathrm{~m}$ from Chamber 2 ), shock arrival times were obtained in a vertical borehole at similar distances. For that test, propagation velocities were $3,636 \mathrm{msec}$ for the 8 - to 16-m interval, and 3,641 msec for the 16- to 32-m interval. Insofar as shock propagation velocities may be taken as one index of in-situ rock properties, there appears to be no significant difference in shock propagation velocities in the first $32 \mathrm{~m}$ of rock above Chambers 2 and 4 .

\section{Accelerations}

Peak accelerations, scaled by the cube-root of the charge yield, are plotted for the five fully successful measurements in Figure 12. Also included for comparison, are data from Tests 2, 3, 5, 6, and 7 of the 1994 UAST series at Magdalena. The UAST events involved charge weights of 72, 344, 943, 2570, and $2890 \mathrm{~kg}$ (of Comp B), respectively, representing chamber-loading densities of 1 to $40 \mathrm{~kg} / \mathrm{m} 3$. All of these tests were detonated in Chamber 4 (see Figure 13), and all involved idealized charges (no munitions) aligned along the central axis at mid-height of the chamber. Cube-root scaling collapsed the UAST data quite well, and it is not possible to distinguish the scaled data by test. The results of the Singapore Ground Shock Test are in good agreement with those from the 1994 tests, and are either uniformly high or low with respect to the previous experiments. Also shown on Figure 12 is a least squares curve fitted to the data. The curve has the equation $A_{s}=3100 R_{s}^{-3.0}$, where $A_{s}$ is the scaled acceleration, and $R_{5}$ is the scaled range. The Singapore Ground Shock Test data lies slightly above the fitted curve, but well within the general data scatter. 


\begin{tabular}{|c|c|c|c|c|c|c|c|}
\hline $\begin{array}{c}\text { Gage } \\
\text { No }\end{array}$ & $\begin{array}{c}\text { Range } \\
(\mathrm{m})\end{array}$ & $\begin{array}{c}\text { Scaled } \\
\text { Range } \\
\left(\mathrm{m} / \mathrm{kg}^{1 / 3}\right)\end{array}$ & $\begin{array}{c}\text { Arrival } \\
\text { Time } \\
\text { (msec) }\end{array}$ & $\begin{array}{c}\text { Peak } \\
\text { Acceleration } \\
\text { (g) }\end{array}$ & $\begin{array}{c}\text { Peak } \\
\text { Velocity } \\
\text { (m/sec) }\end{array}$ & $\begin{array}{l}\text { Peak } \\
\text { Displace- } \\
\text { ment } \\
(\mathrm{mm})\end{array}$ & $\begin{array}{c}\text { Scaled } \\
\text { Acceleration } \\
\left(\mathrm{g} \times / \mathrm{kg}^{1 / 3}\right)\end{array}$ \\
\hline $204 A$ & 4 & 0.45 & 0.484 & 5400 & 9.95 & 4.5 & 47790 \\
\hline $204 B$ & 4 & 0.45 & 0.453 & 5183 & 9.70 & 4.21 & 45870 \\
\hline $208 A$ & 8 & 0.90 & 1.15 & 996 & 0.95 & 0.59 & 8815 \\
\hline $208 B$ & 8 & 0.90 & 1.15 & Note (1) & - & -. & - \\
\hline $216 \mathrm{~A}$ & 16 & 1.81 & 3.11 & 167.5 & 0.37 & 0.50 & 1482 \\
\hline $216 B$ & 16 & 1.81 & 3.14 & 145.4 & 0.35 & 0.52 & 1287 \\
\hline $232 A$ & 32 & 3.62 & 7.30 & Note (2) & - & -- & -- \\
\hline $232 B$ & 32 & 3.62 & 7.39 & Note (3) & - & -- & -- \\
\hline \multicolumn{8}{|c|}{$\begin{array}{l}\text { Notes: } \\
\text { (1) Data amplitude in error; amplitudes not reported. } \\
\text { (2) Severe signal oscillation at } 150 \mathrm{~Hz} \text {; no amplitudes reported. } \\
\text { (3) Gage or cable damage; no data recorded. }\end{array}$} \\
\hline
\end{tabular}




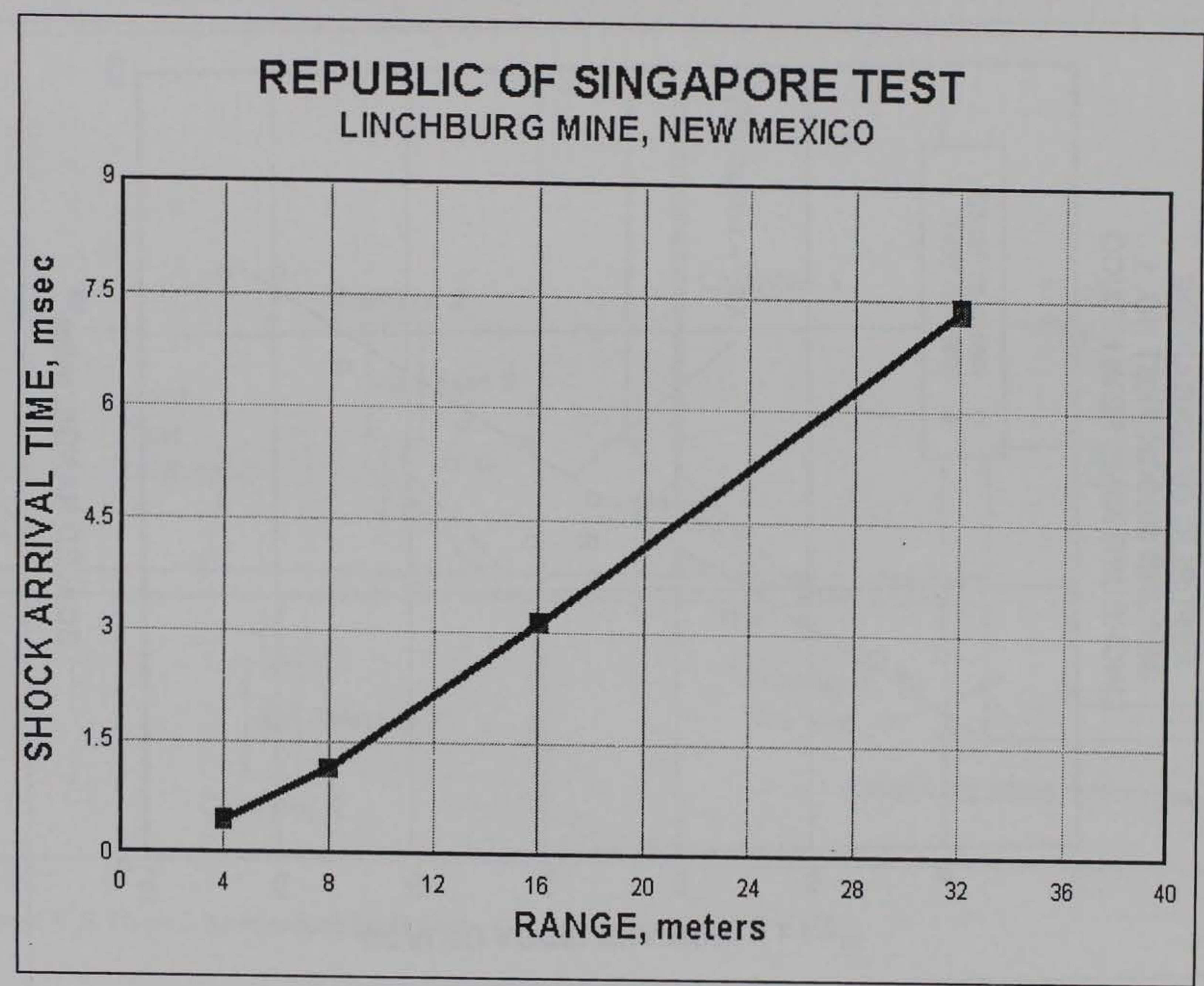

Figure 11. Ground shock arrival times versus range 


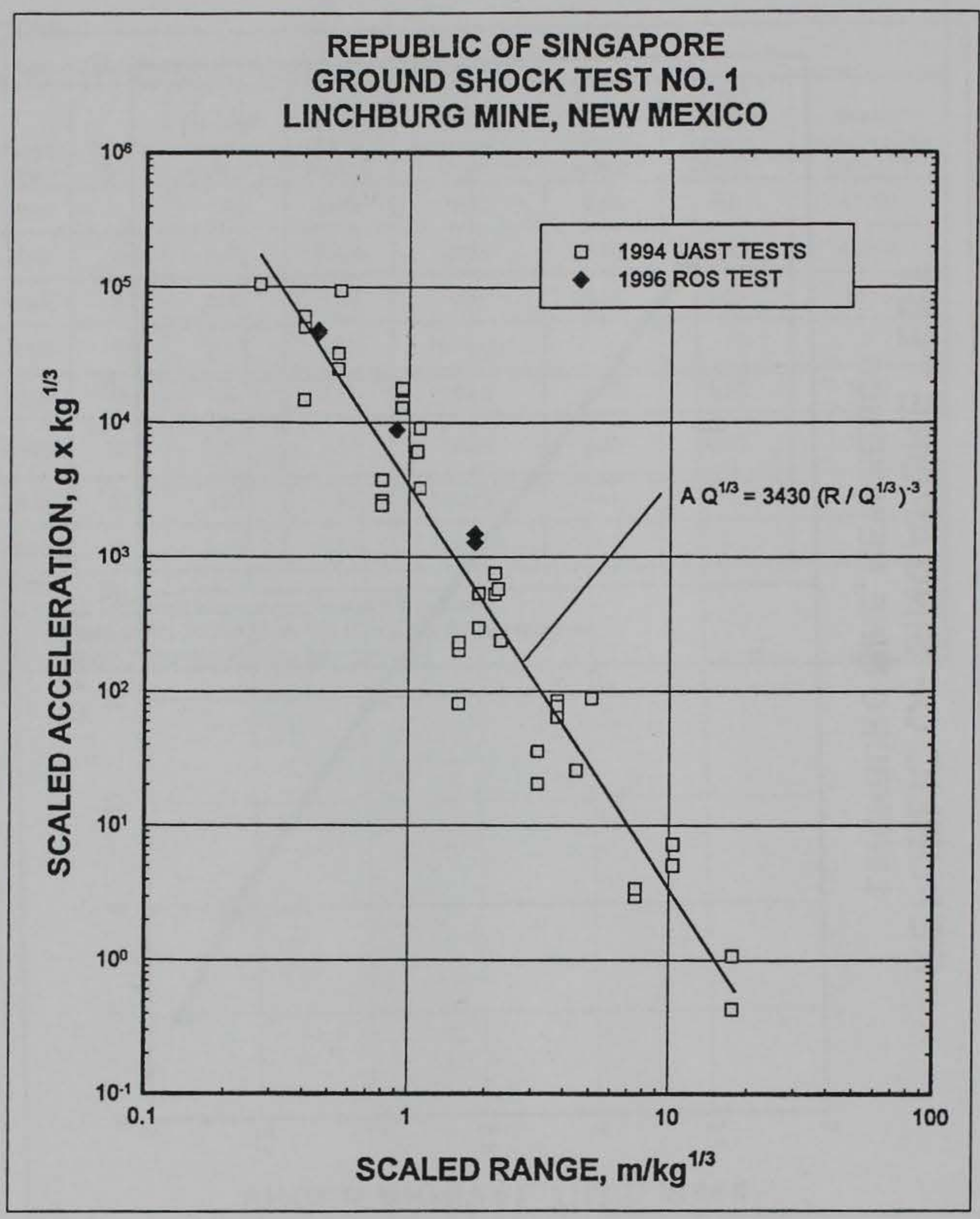

Figure 12. Scaled peak acceleration versus scaled range 


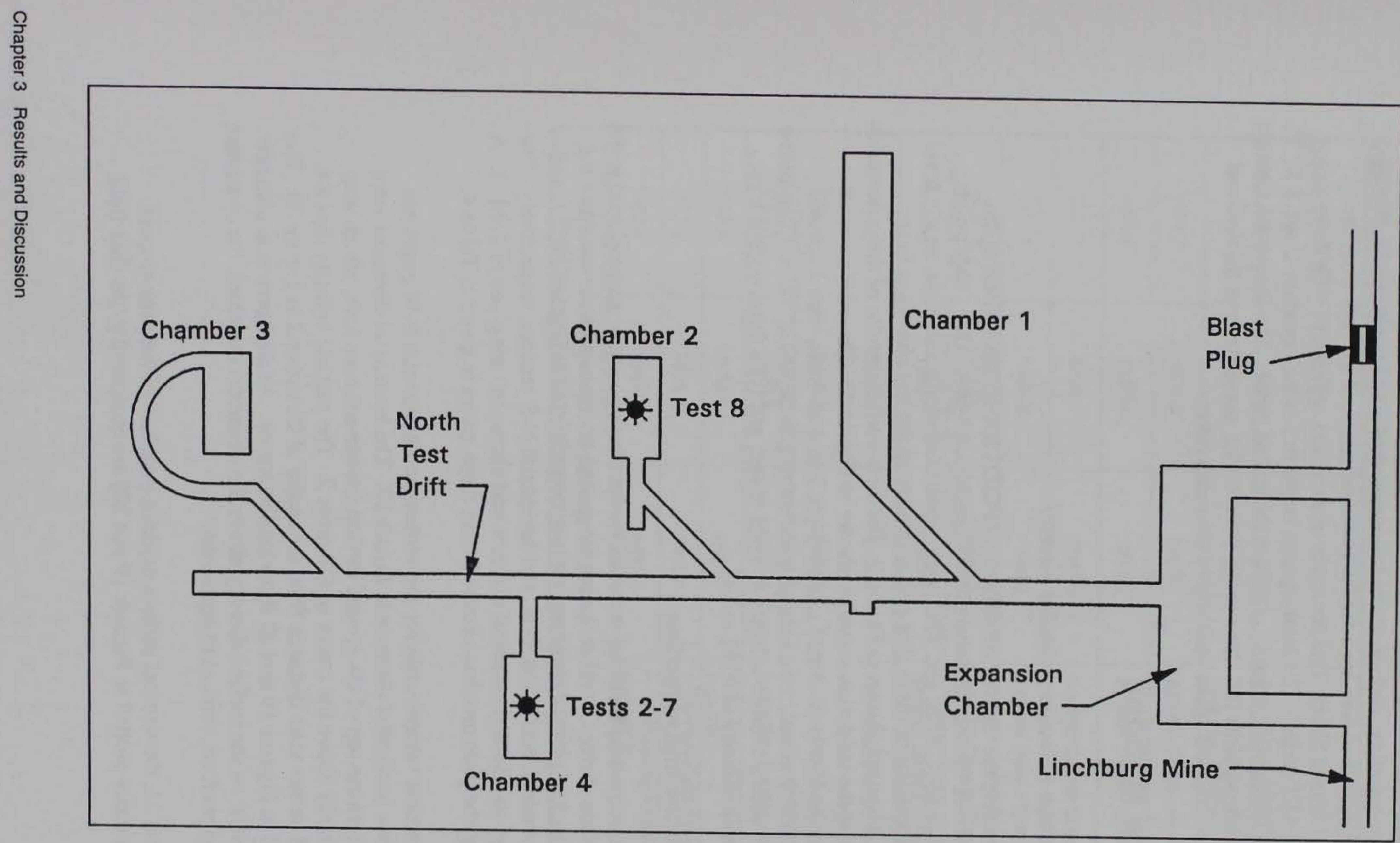

Figure 13. Location of U.S. Phase 3 Intermediate-Scale tests 


\section{Particle velocity}

Free-field particle velocities were derived from the acceleration data by numerical integration, and are plotted versus scaled range in Figure 14. The data spread is tighter than was seen for the accelerations, and the data from the Singapore Ground Shock Test are again in excellent agreement with those from the 1994 UAST series. The least squares curve fit has the equation $U=1.8 R_{s}{ }^{-2.5}$, where $U$ is the particle velocity and $R_{s}$ is the scaled range. The Singapore Ground Shock Test data points fall close to the fitted curve, particularly at the $4 \mathrm{~m}$ and $16 \mathrm{~m}$ ranges, and are again well within the data scatter.

\section{Surface Motions}

\section{Near-surface seismic velocity survey}

A refraction survey was conducted by FC/DTRA on the surface of the mountain above the test chambers in the Linchburg Mine. Three shot points, designated as SPA, SPB, and SPC, were positioned along a straight, nearly level line. The locations of these shot points relative to the test chambers in the Linchburg Mine are shown in Figure 7. The near-surface profile of the overburden inferred from the refraction survey is shown in Figure 15. Three layers were identified: (a) a highly fractured surface layer 3-to 4-m thick, with a seismic velocity of $638.9 \mathrm{~m} / \mathrm{sec}$, (b) a second layer ranging to depths of $12-$ to $17-\mathrm{m}$ below the surface, with a seismic velocity of $1175 \mathrm{~m} / \mathrm{sec}$, and (c) a third, deeper layer, with a seismic velocity of $2162 \mathrm{~m} / \mathrm{sec}$.

\section{Accelerations and velocities}

Acceleration-time histories recorded by the triaxial seismic gages placed at the ground surface above Chamber 2 were integrated to obtain particle velocity time histories. Stacked plots of these waveforms are presented in Figures 16, 17, and 18 for the vertical, horizontal E-W, and horizontal N-S sensors, respectively. The surface gage locations (horizontal distance and elevation) are given in Table 3. A summary of the peak motions obtained from these gages is given in Table 4 .

Peak particle velocity data for the vertical and horizontal E-W gages are plotted versus horizontal distance in Figure 19. The horizontal distances were measured from the top of the ground motion instrument bore hole, which was nearly vertically above the center of Chamber 2 . The particle velocity data are also plotted versus slant distance from the center of Chamber 2 in Figure 20. The data plotted in Figures 19 and 20 show similar trends. As the horizontal distance (from the point on the surface directly above the chamber) increases, the dominant motion changes from vertical to horizontal.

In Figure 21, the vertical surface motions (one half of the peak-to-peak vertical velocities plotted in Figures 19 and 20) are compared to the free-field motions 


\begin{tabular}{|c|c|c|c|}
\hline \multicolumn{2}{|c|}{ Horizontal Coordinates } & \multirow[b]{2}{*}{$\begin{array}{c}\text { Elevation } \\
(\mathrm{m})\end{array}$} & \multirow[b]{2}{*}{ Remarks } \\
\hline $\begin{array}{c}X \\
(m)\end{array}$ & $\begin{array}{c}Y \\
(m)\end{array}$ & & \\
\hline 1855.9 & 1523.8 & 2576.0 & $\begin{array}{l}\text { Top of Ground Motion Instrument } \\
\text { Hole from Chamber } 2\end{array}$ \\
\hline 1855.7 & 1505.4 & 2577.1 & Seismic Sensor Station $1 \mathrm{~A}$ \\
\hline 1852.9 & 1527.2 & 2575.2 & Seismic Sensor Station $1 B$ \\
\hline 1883.7 & 1572.8 & 2586.0 & Seismic Sensor Station $1 C$ \\
\hline 1870.1 & 1599.9 & 2584.2 & Seismic Sensor Station $1 D$ \\
\hline 1880.8 & 1619.3 & 2587.3 & Seismic Sensor Station $1 \mathrm{E}$ \\
\hline 1889.5 & 1684.7 & 2584.9 & Seismic Sensor Station $1 \mathrm{~F}$ \\
\hline 1907.2 & 1655.2 & 2590.7 & Refraction Survey, Shot Point A \\
\hline 1904.0 & 1617.7 & 2591.1 & Refraction Survey, Shot Point B \\
\hline 1907.1 & 1580.6 & 2591.4 & Refraction Survey, Shot Point C \\
\hline 1587.0 & 1552.4 & 2453.8 & $\begin{array}{l}\text { WES-Free-Field Airblast Gage } \\
\text { (59ABSO) }\end{array}$ \\
\hline 1582.3 & 1551.4 & 2453.8 & $\begin{array}{l}\text { WES-Free-Field Airblast Gage } \\
(60 \mathrm{ABSO})\end{array}$ \\
\hline 1562.4 & 1547.3 & 2453.6 & $\begin{array}{l}\text { WES-Free-Field Airblast Gage } \\
(63 \mathrm{ABSO})\end{array}$ \\
\hline $\begin{aligned} & \text { Notes: } \text { Basi } \\
& \text { Eleve } \\
& \text { Eleve } \\
&\end{aligned}$ & $\begin{array}{l}\text { s arbitra } \\
\text { in Gage } \\
\text { ytrigono } \\
\end{array}$ & g, with ac & of $\pm 0.05 \mathrm{~m}$. \\
\hline
\end{tabular}




\begin{tabular}{|c|c|c|c|c|c|c|c|c|}
\hline \multirow[t]{2}{*}{$\begin{array}{l}\text { Station } \\
\text { No. } \\
\end{array}$} & \multirow[t]{2}{*}{$\begin{array}{c}\text { Gage } \\
\text { Orientation } \\
\end{array}$} & \multirow[t]{2}{*}{$\begin{array}{l}\text { Arrival } \\
\text { Time } \\
\text { (msec) } \\
\end{array}$} & \multicolumn{2}{|c|}{$\begin{array}{c}\text { Peak } \\
\text { Acceleration } \\
\text { (g's) } \\
\end{array}$} & \multicolumn{2}{|c|}{$\begin{array}{l}\text { Peak Particle Velocity } \\
(\mathrm{mm} / \mathrm{sec})\end{array}$} & \multicolumn{2}{|c|}{$\begin{array}{l}\text { Peak Displacement } \\
(\mathrm{mm})\end{array}$} \\
\hline & & & $(+)$ & $(-)$ & $(+)$ & $(-)$ & $(+)$ & $(-)$ \\
\hline $1 \mathrm{AC1}$ & Vertical & 3402 & 0.4517 & 0.5818 & 11.619 & 16.688 & 0.07122 & 0.03538 \\
\hline $1 \mathrm{AC2}$ & Horiz (E-W) & 3402 & 0.1623 & 0.1701 & 4.795 & 3.847 & -- & -. \\
\hline $1 \mathrm{ACB}$ & Horiz (N-S) & 3402 & 0.2353 & 0.2013 & 6.684 & 6.364 & -- & 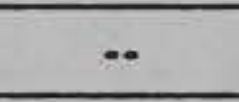 \\
\hline $1 \mathrm{BC} 1$ & Vertical & 3402 & 0.2265 & 0.2842 & 8.690 & 9.528 & 0.08123 & 0.00275 \\
\hline $1 \mathrm{BC} 2$ & Horiz (E-W) & 3408 & 0.1633 & 0.1531 & 3.944 & 5.435 & $\ldots$ & -. \\
\hline $1 \mathrm{BC} 3$ & Horiz (N-S) & 3404 & 0.0661 & 0.0689 & 3.688 & 2.530 & 0.02251 & 0.01864 \\
\hline $1 \mathrm{CC} 1$ & Vertical & 3406 & 0.1773 & 0.1759 & 4.544 & 6.224 & 0.02873 & 0.01143 \\
\hline $1 \mathrm{CC} 2$ & Horiz (E-W) & 3410 & 0.0840 & 0.0889 & 2.740 & 2.966 & 0.01354 & 0.02034 \\
\hline $1 \mathrm{CC} 3$ & Horiz (N-S) & 3408 & 0.0720 & 0.0687 & 1.540 & 2.396 & 0.01034 & 0.01204 \\
\hline $1 \mathrm{DC2}$ & Horiz (E-W) & 3410 & 0.1161 & 0.0923 & 2.408 & 1.882 & 0.01958 & 0.01605 \\
\hline $10 \mathrm{DC} 3$ & Horiz (N-S) & 3412 & 0.1201 & 0.0980 & 2.654 & 2.052 & - & - \\
\hline $1 \mathrm{EC1}$ & Vertical & 3412 & 0.0115 & 0.1294 & 2.940 & 4.380 & 0.01773 & 0.01052 \\
\hline $1 \mathrm{EC2}$ & Horiz (E-W) & 3414 & 0.1509 & 0.1182 & 5.596 & 3.569 & 0.02118 & 0.01961 \\
\hline $1 \mathrm{EC} 3$ & Horiz (N-S) & 3414 & 0.1297 & 0.1089 & 3.581 & 3.301 & -- & - \\
\hline $1 \mathrm{FC1}$ & Vertical & 3422 & 0.0518 & 0.0464 & 1.318 & 1.767 & 0.00953 & 0.00528 \\
\hline $1 \mathrm{FC2}$ & Horiz (E-W) & 3424 & 0.0583 & 0.0509 & 1.522 & 1.419 & 0.00887 & 0.00889 \\
\hline 1 FC3 & Horiz $(\mathrm{N}-\mathrm{S})$ & 3426 & 0.0795 & 0.0646 & 2.032 & 1.772 & 0.01154 & 0.00675 \\
\hline
\end{tabular}




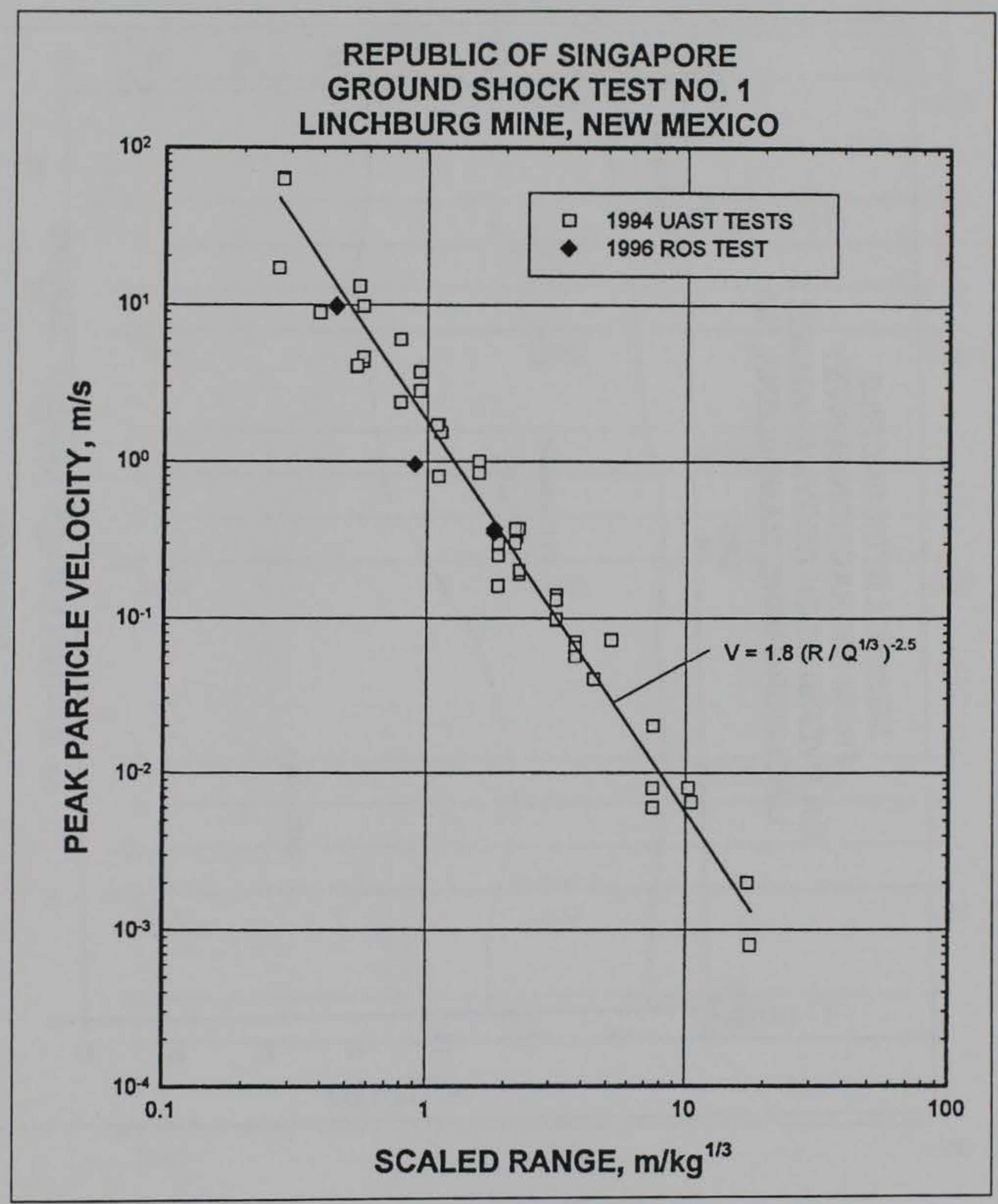

Figure 14. Peak particle velocity versus scaled range 


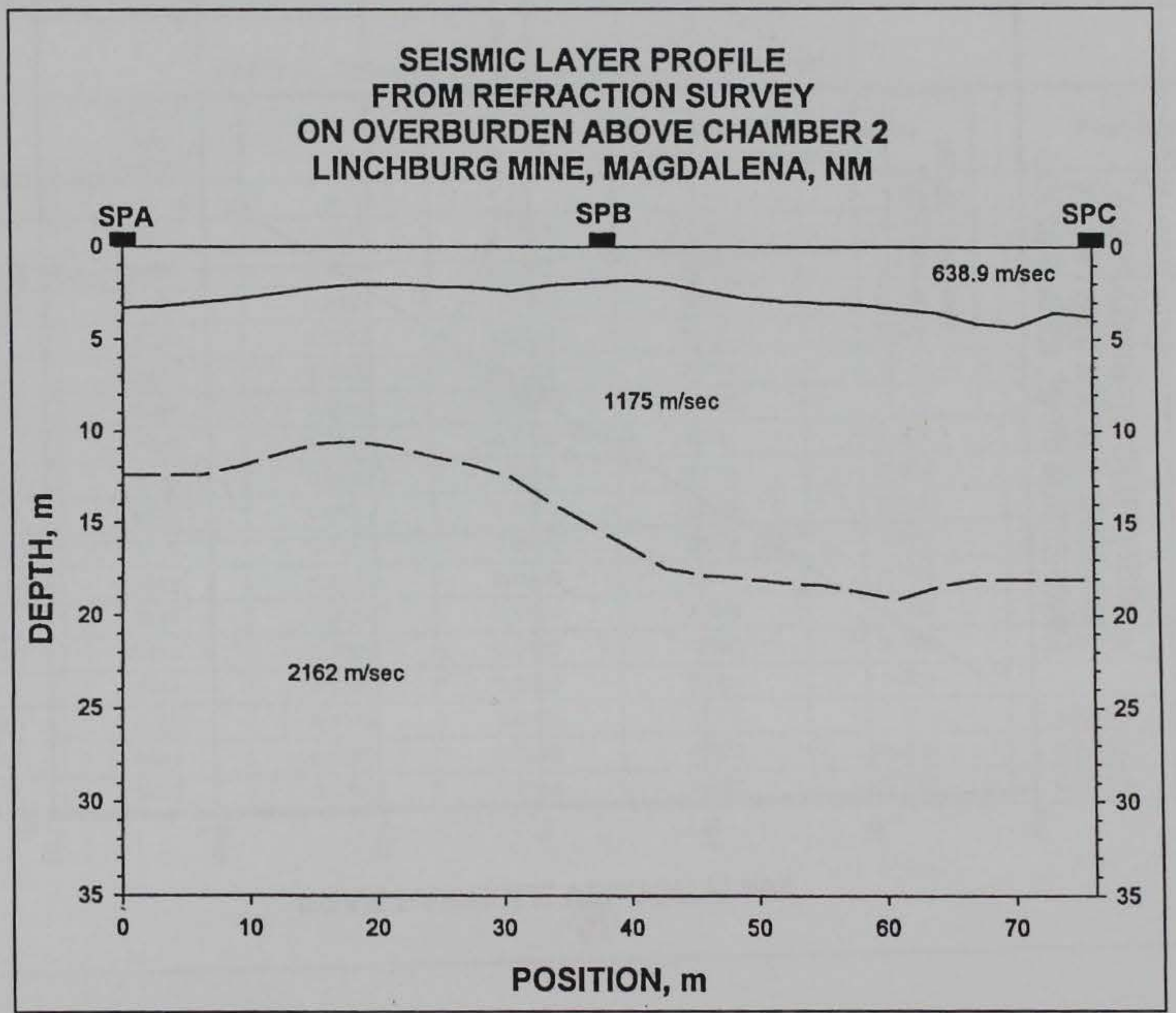

Figure 15. Seismic profile from refraction survey of overburden above test chamber at Linchburg Mine 


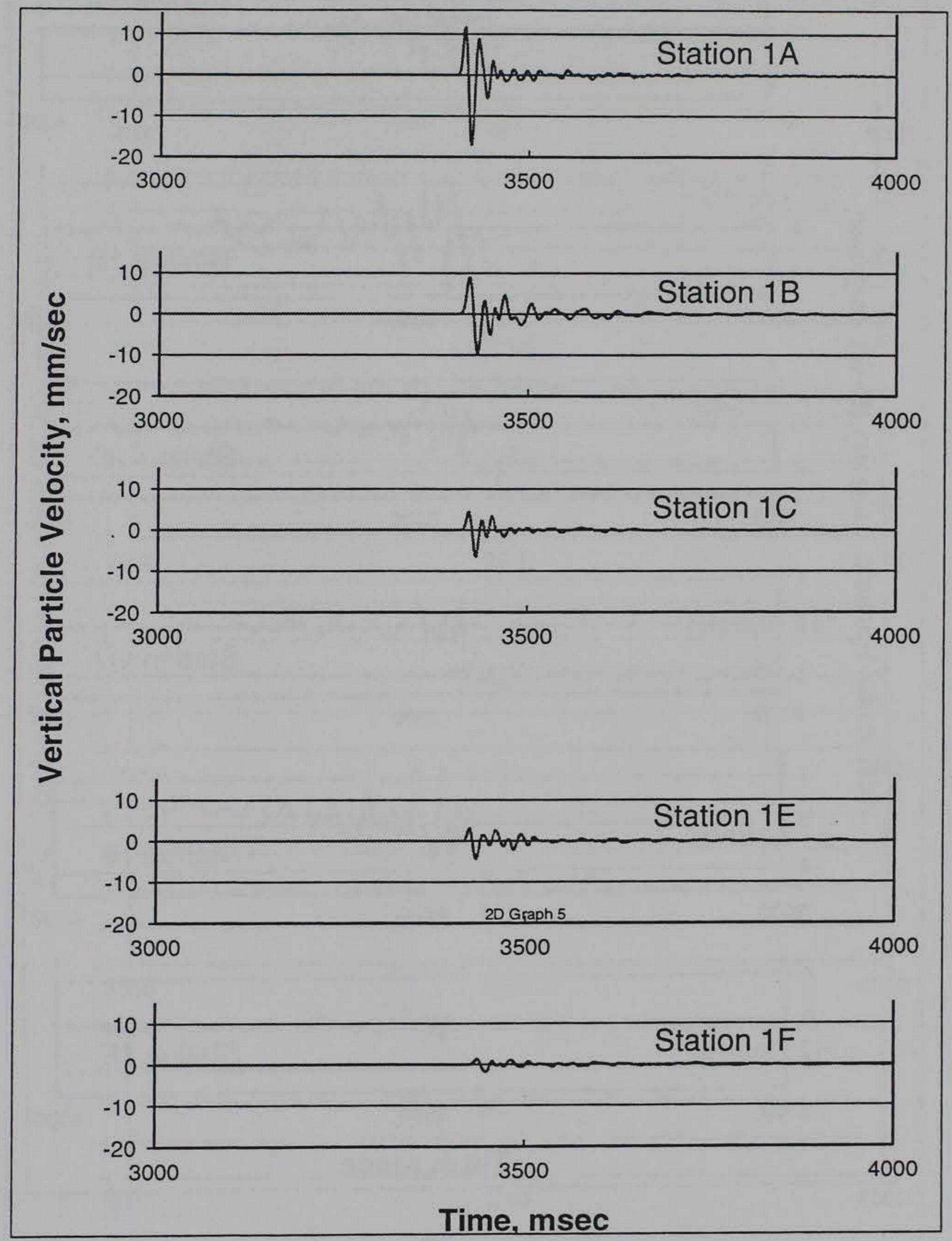

Figure 16. Vertical particle velocity-time histories from seismic transducers located on the overburden surface above Chamber 2, Singapore Ground Shock Test 


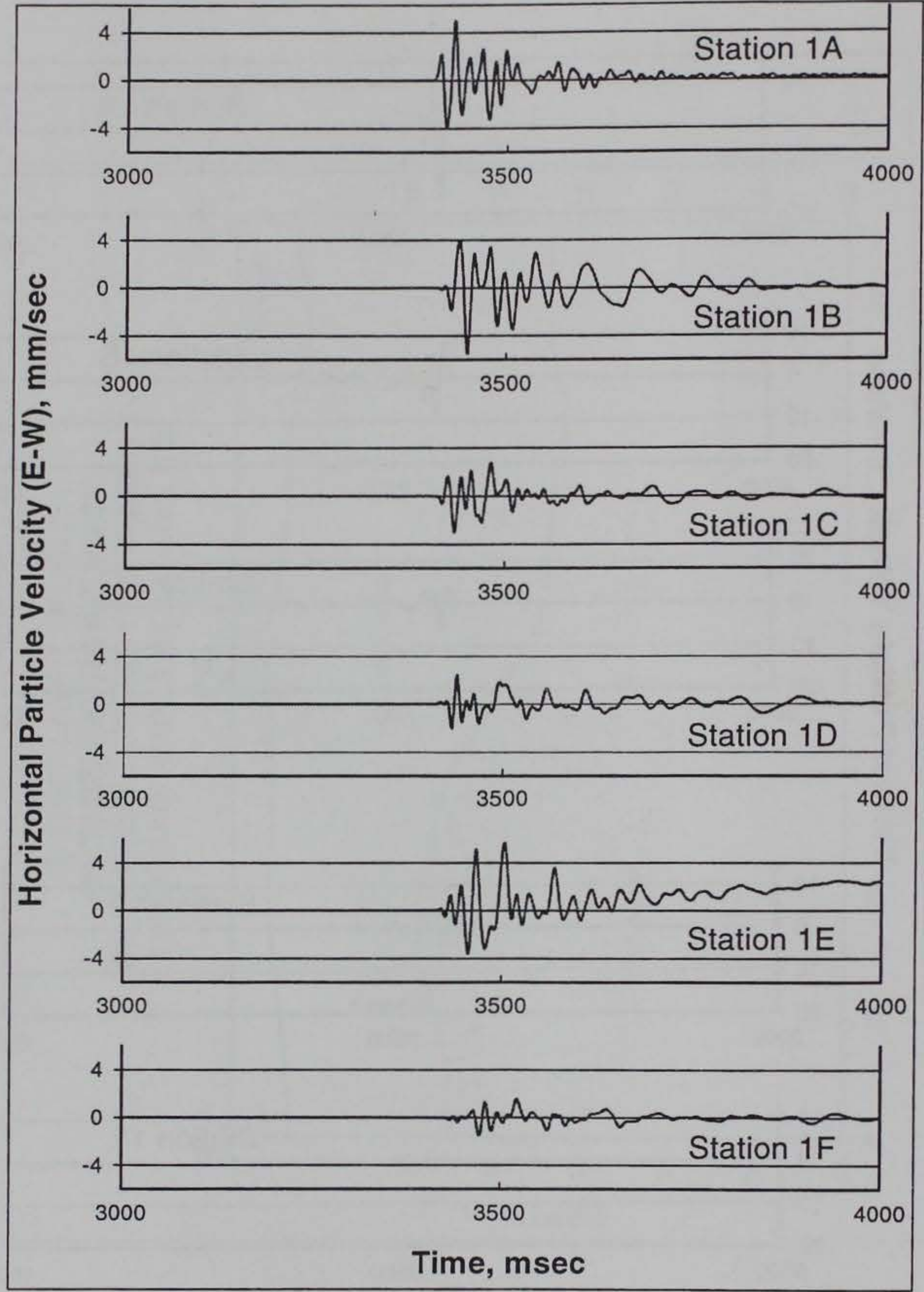

Figure 17. Horizontal (E-W) particle velocity-time histories from seismic transducers located on the overburden surface above Chamber 2, Singapore Ground Shock Test (Fig 18) 


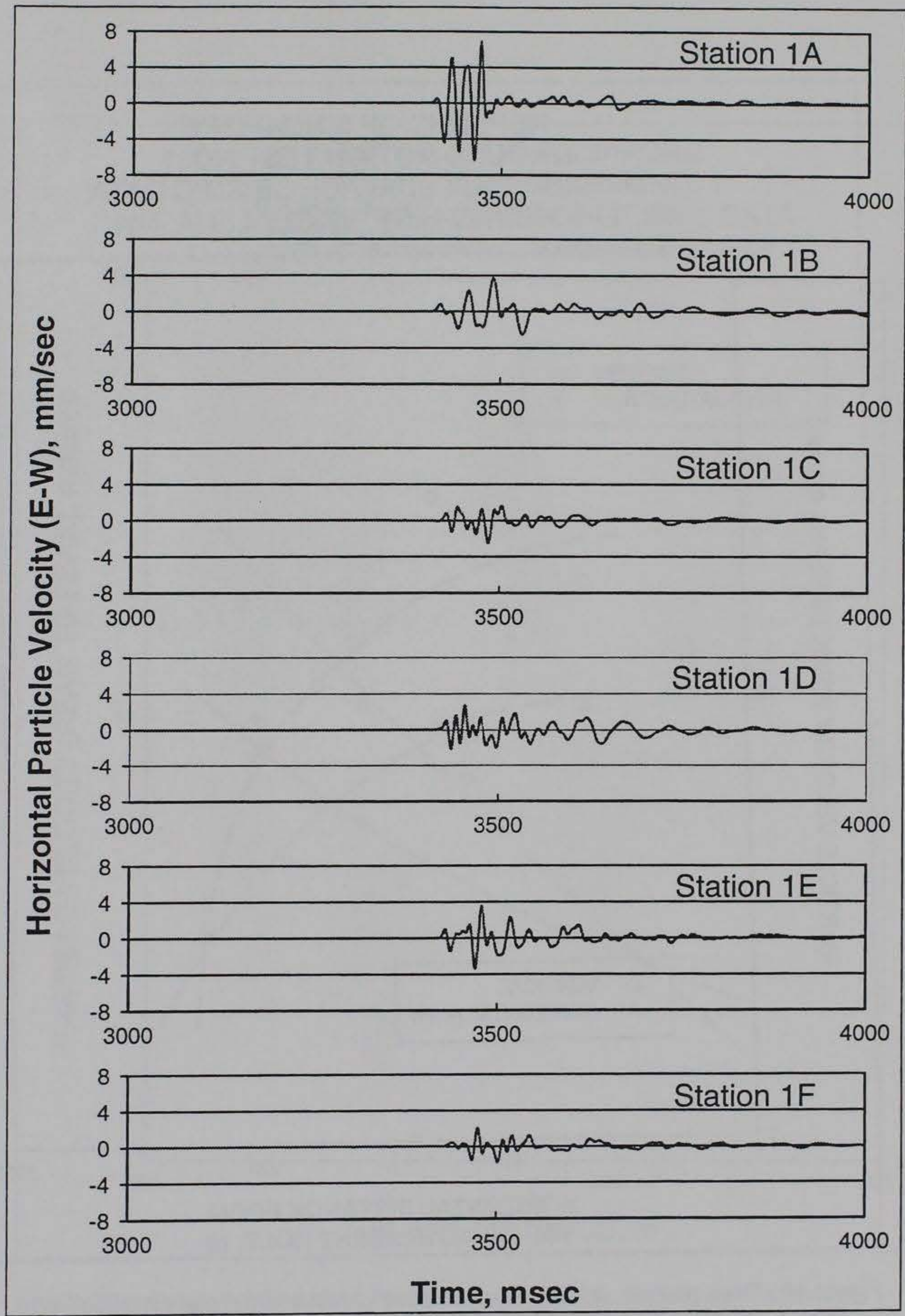

Figure 18. Horizontal (N-S) particle velocity-time histories from seismic transducers located on the overburden surface above Chamber 2 , Singapore Ground Shock Test 


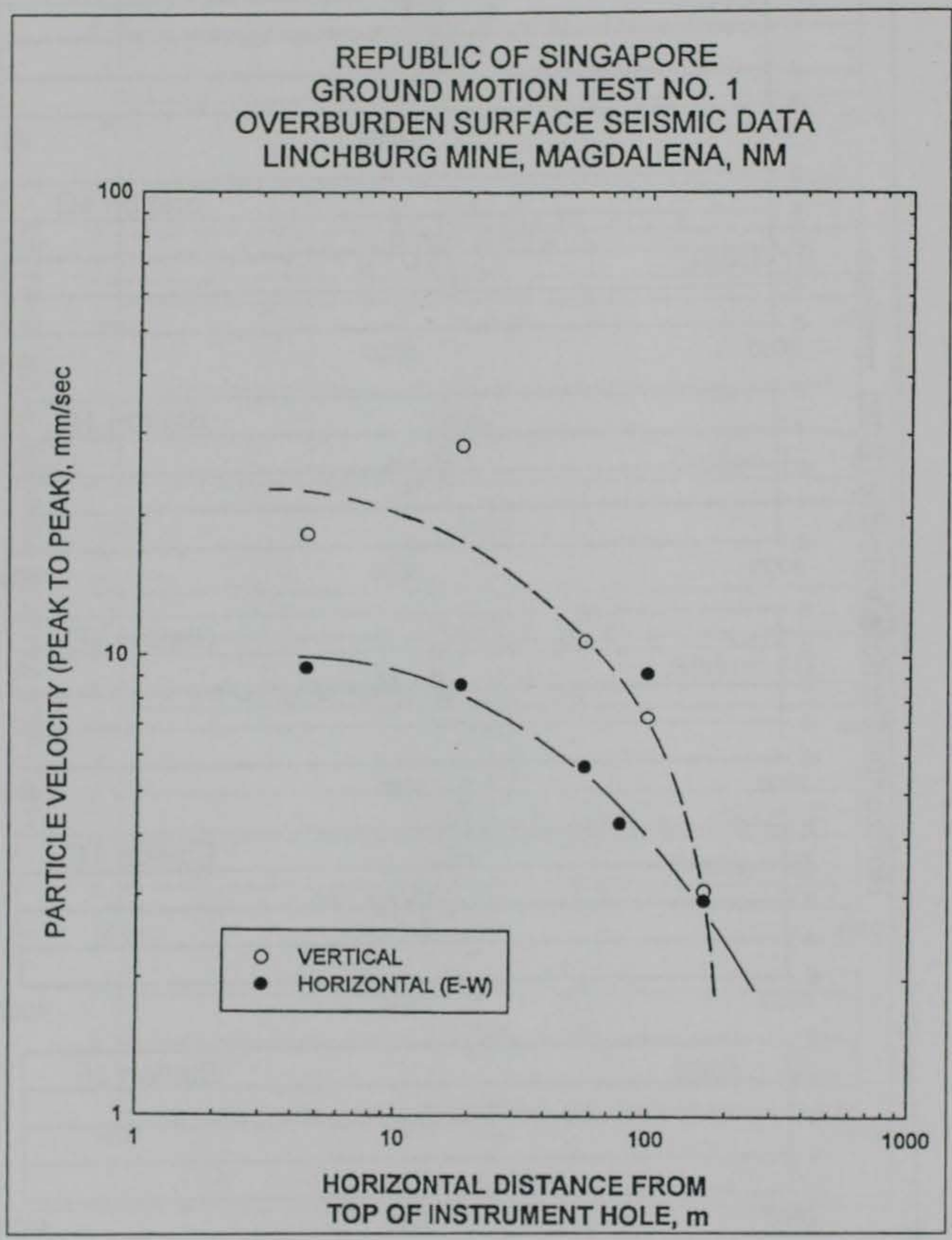

Figure 19. Peak particle velocity (peak to peak) versus horizontal distance from the top of the instrument hole, Singapore Ground Shock Test 


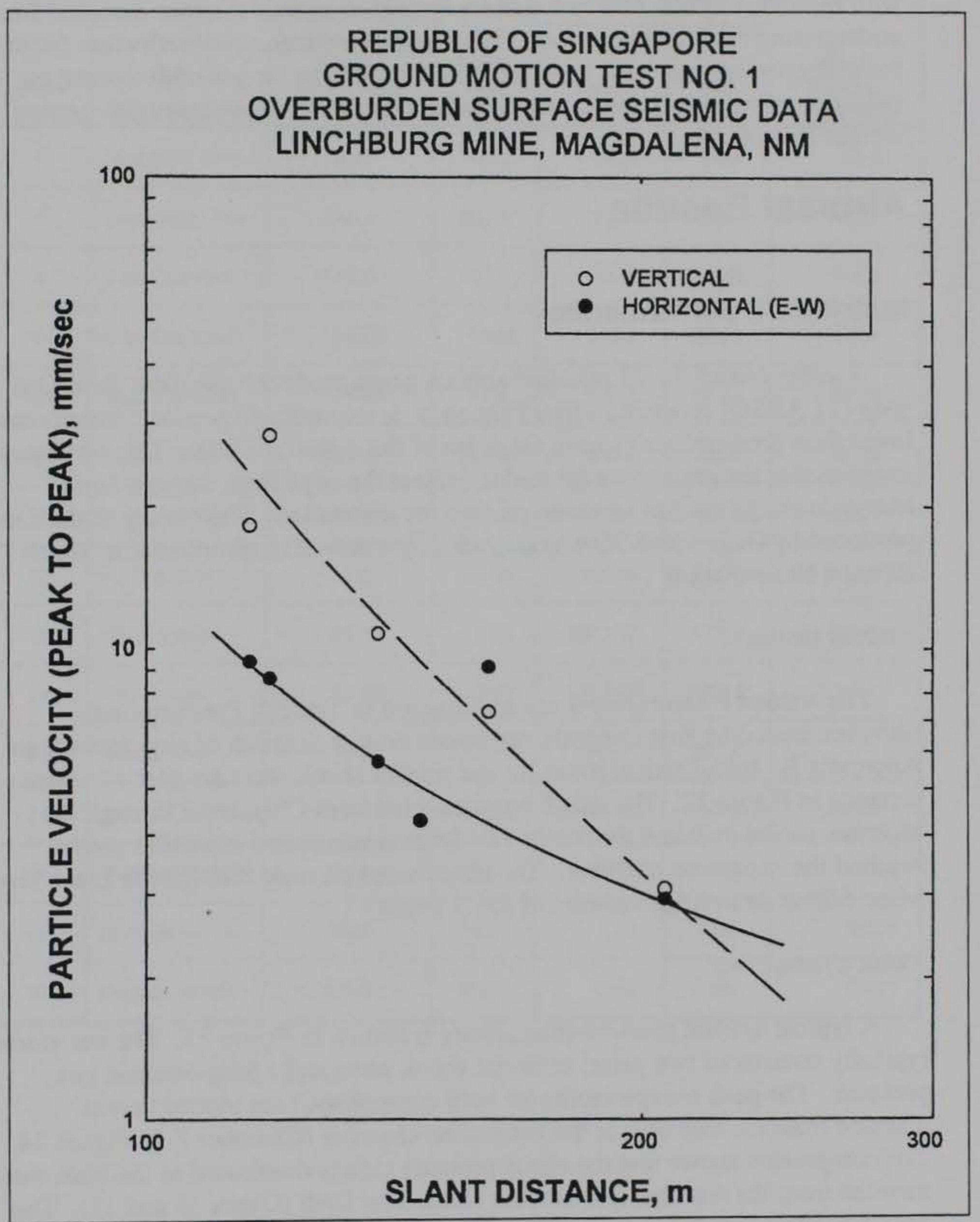

Figure 20. Peak particle velocity (peak to peak) versus slant distance from the center of the explosive charge, Chamber 2, Singapore Ground Shock Test 
(radial particle velocity measurements shown in Figure 14). The surface particle velocity data are internally consistent, and attenuate with increased slant range at the same rate as the main body of data plotted in Figure 21. The surface motions are two to four times greater than the free-field velocities. This is slightly greater than the theoretical free-surface reflection factor of 2 , but is in good agreement with reflection factors of 3 to 5 that are typical of surface motions recorded from underground nuclear detonations. The higher-than-theoretical reflection factors for underground tests have been attributed, in part, to the generally occurring reduction of material seismic velocity with decreasing depth below the ground surface (Figure 15).

\section{Airblast Results}

\section{Instrument performance}

Twenty-one of the 23 installed airblast gages produced excellent data. One gage (21 ABSO) produced a low-frequency, low-amplitude pressure record--much lower than predicted and within the noise of the digital recorder. This condition suggests that the gage cover (placed to protect the gage from damage during charge loading) was not removed prior to the detonation. The quality of the data produced by Gage 10ABSO was degraded by a defective discriminator, which affected bit resolution.

\section{Arrival times}

The airblast measurements are summarized in Table 5. Pressure-timehistories, including first integrals, are presented to a duration of nine seconds in Appendix B. Initial arrival times for the airblast shock wave are plotted versus distance in Figure 22. The shock wave traveled from Chamber 2 through the chamber access drift and the North Test Drift at supersonic velocities until it reached the expansion chamber. The shock wave traveled through the Linchburg Mine drift at an average velocity of $353.7 \mathrm{~m} / \mathrm{sec}$.

\section{Peak pressures}

A typical airblast pressure-time history is shown in Figure 23. The waveform typically consists of two parts; an initial shock wave and a long-duration gas pressure. The peak overpressures (of both components) are plotted versus distance from the rear wall of the detonation chamber (Chamber 2) in Figure 24. The comparison shows that the shock pressure clearly dominated as the blast wave traveled from the test chamber into the North Test Drift (Gages 16 and 11). The peak pressures calculated for this test, using the BLASTX computer code (Version 3.5.3), are included in Figure 24 for comparison.

After the blast wave entered the expansion chamber, reflections and rarefactions of the shock reduced the peak shock pressures to values near those of the gas pressures (Gages $1 \mathrm{OB}$ and $10 \mathrm{C}$ ). As the blast wave traveled down the 
Table 5.

Airblast Data Summary

\begin{tabular}{|c|c|c|c|c|c|c|}
\hline \multirow[b]{2}{*}{$\begin{array}{c}\text { Gage } \\
\text { No. }\end{array}$} & \multirow[b]{2}{*}{ Gage Location } & \multirow{2}{*}{$\begin{array}{c}\text { Distance } \\
\text { from Rear } \\
\text { Wall of } \\
\text { Chamber } 2 \\
\text { (m) }\end{array}$} & \multirow[b]{2}{*}{$\begin{array}{c}\text { Arrival } \\
\text { Time } \\
\text { (msec) }\end{array}$} & \multicolumn{2}{|c|}{ Peak Pressure } & \multirow[b]{2}{*}{$\begin{array}{c}\text { Peak } \\
\text { Impulse } \\
\text { (kPa-sec) }\end{array}$} \\
\hline & & & & $\begin{array}{l}\text { Shock } \\
(\mathrm{kPa})\end{array}$ & $\begin{array}{c}\text { Gas } \\
(\mathrm{kPa})\end{array}$ & \\
\hline 1 & Linchburg Mine & 323.7 & 746.6 & 18.90 & 4.29 & 23.83 \\
\hline 3 & Linchburg Mine & 246.4 & 529.4 & 26.32 & 19.46 & 105.5 \\
\hline 4 & Exp. Chamber & 182.6 & 347.7 & 39.46 & 34.38 & 174.1 \\
\hline $10 \mathrm{~A}$ & Exp. Chamber & 89.98 & 98.66 & 111.9 & 82.81 & 338.2 \\
\hline $10 B$ & Exp. Chamber & 75.98 & 71.97 & 142.2 & 96.39 & 393.3 \\
\hline $10 D$ & Exp. Chamber & 89.98 & 97.64 & 133.2 & 102.6 & 387.9 \\
\hline 11 & N. Test Drift & 50.67 & 37.56 & 598.5 & 124.6 & 523.4 \\
\hline 16 & N. Test Drift & 39.51 & 24.16 & 835.6 & 161.8 & 430.4 \\
\hline 18 & Ch. Access & 25.19 & 9.53 & 2911.00 & 437.6 & 248.1 \\
\hline 19 & Ch. Access & 20.82 & 6.08 & 2705.00 & 1534.0 & - \\
\hline 20 & Debris Tray & 14.73 & 4.96 & -- & 32.12 & -- \\
\hline 21 & Debris Tray & 16.13 & 5.81 & 15072.00 & 1147.0 & $1,049.0$ \\
\hline 59 & Outside Portal & 334.9 & 807.3 & 3.77 & 1.05 & 0.083 \\
\hline 60 & Outside Portal & 339.9 & 793.3 & 2.36 & 2.06 & 0.035 \\
\hline 63 & Outside Portal & 359.9 & 866.6 & 0.68 & 0.089 & 0.013 \\
\hline
\end{tabular}




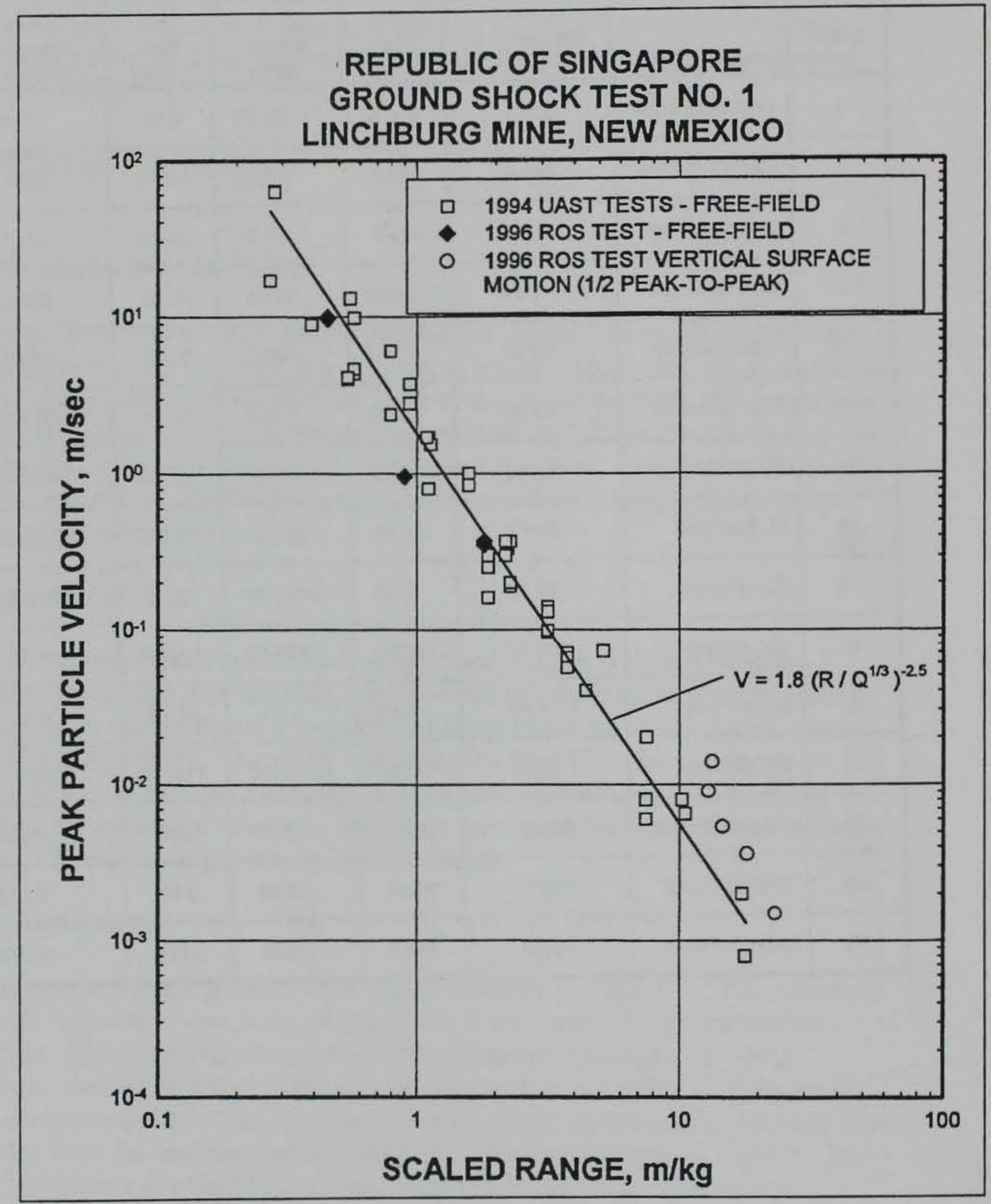

Figure 21. Comparison of vertical surface motion particle velocities (open circle symbols) with radial free-field velocities, all as a function of scaled range from the charge center, Singapore Ground Shock Test 


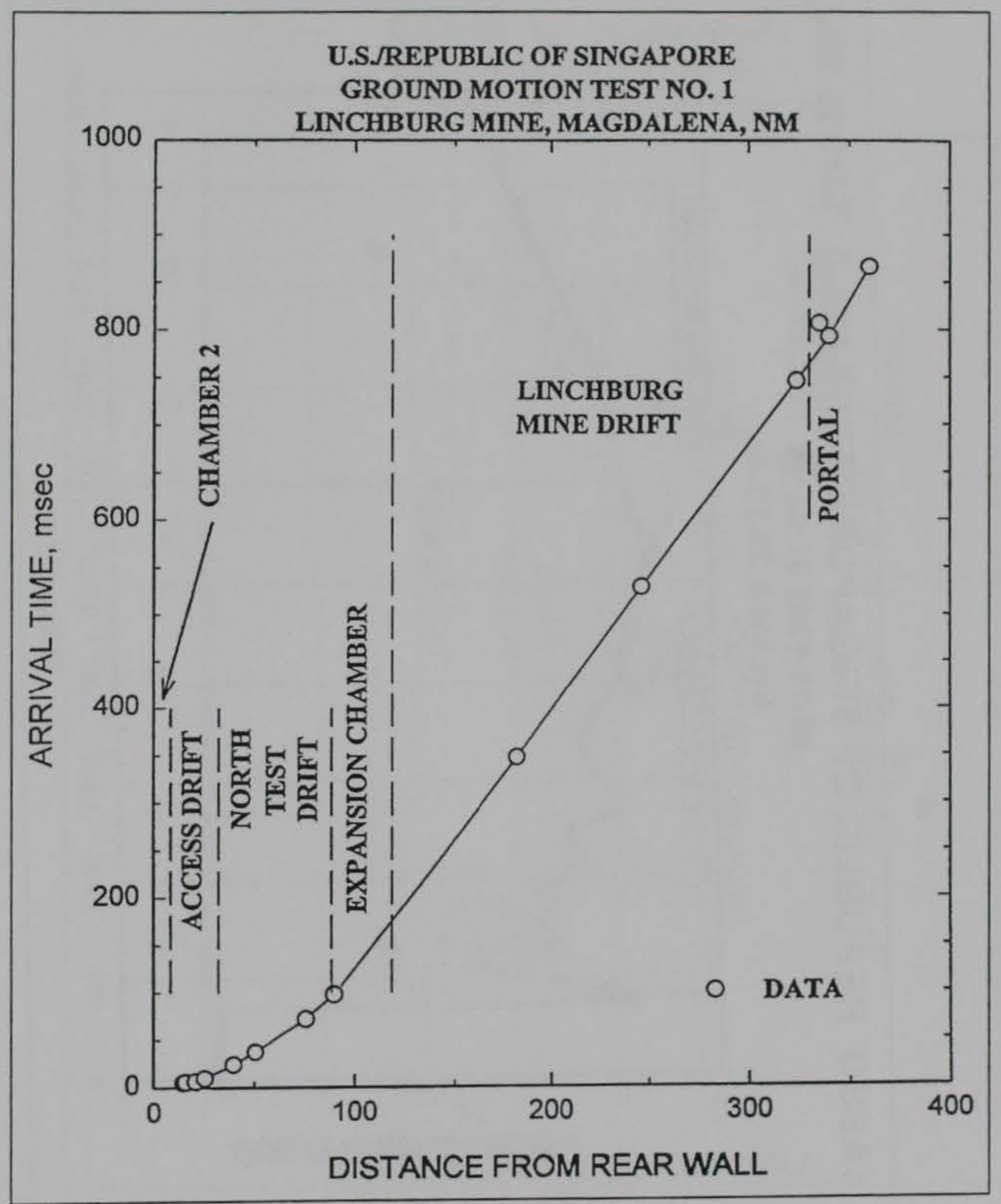

Figure 22. Airblast shock front arrival time versus distance from the rear wall of Chamber 2, Singapore Ground Shock Test 


\section{ABSO REPUBLIC OF SINGAPORE TEST NO. 1 Tdr035.002} 06-18-1996 02:00:35

Cal val $=28.10$

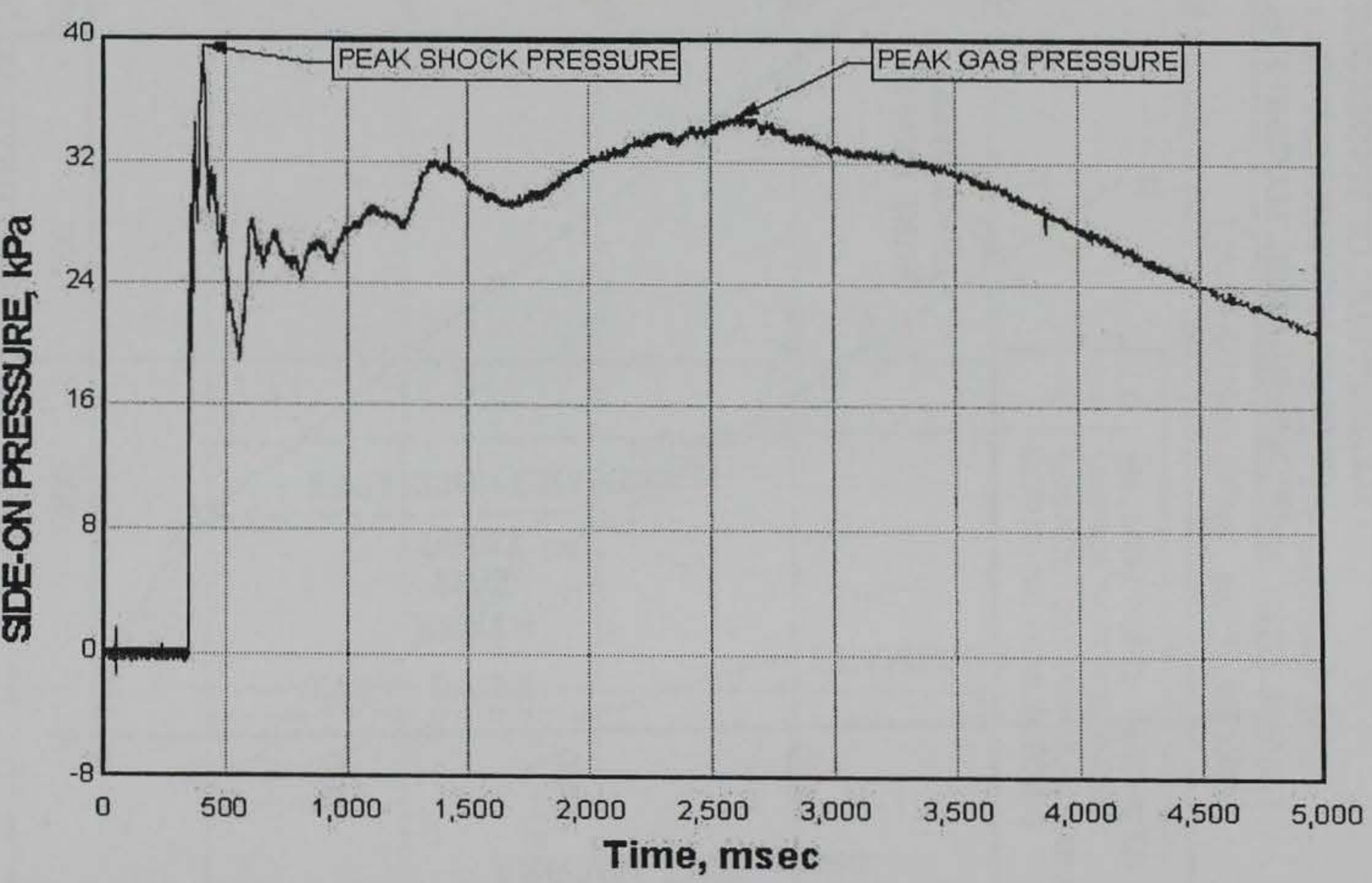

Figure 23. Typical underground airblast pressure-time history with shock and gas components, Singapore Ground Shock Tests 


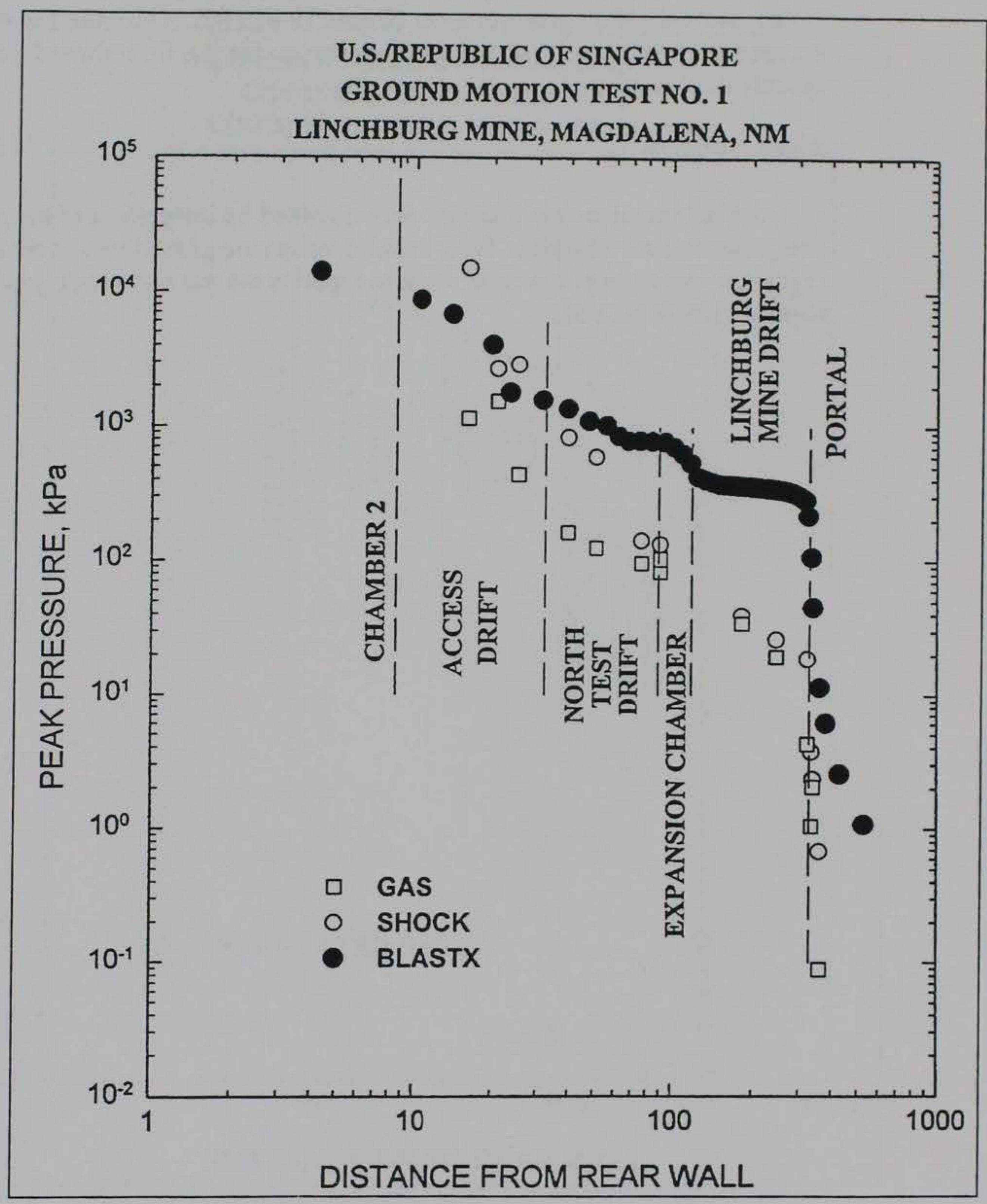

Figure 24. Peak overpressure versus distance from the rear wall of Chamber 2, Singapore Ground Shock Test 
Linchburg Mine, the gas pressures dropped steadily with the additional engulfed volume. The shock front, however, reformed and moved toward the portal as more-or-less one-dimensional wave propagation, with little loss of energy (Gage 1). The shock front emerged from the tunnel portal and traveled at sonic velocity toward the external gages, where its brief passage is clearly seen as an initial, short-duration pressure spike (Gages 59 and 60). Once the gas pressure escaped the confinement of the tunnel, however, the gas flow slowed down and quickly dissipated.

\section{Peak impulse}

Airblast impulse-time histories were obtained by integration of the recorded overpressure-time histories. Peak impulse values are plotted versus distance in Figure 25. An attempt has been made to separate the gas and shock-produced impulse, where possible. 


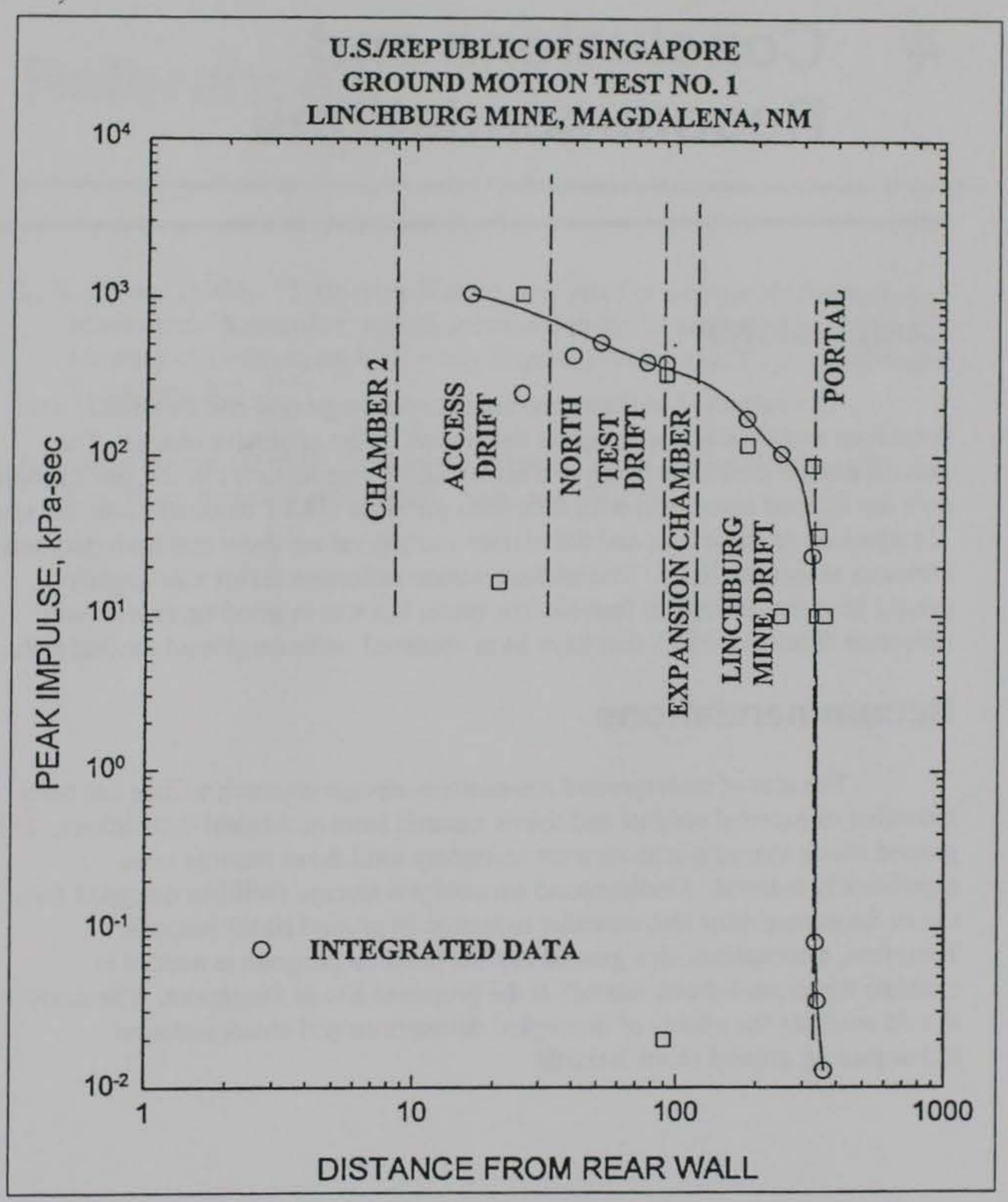

Figure 25. Peak overpressure impulse versus distance from rear wall of Chamber 2, Singapore Ground Shock Test 


\section{Conclusions and Recommendations}

\section{Conclusions}

The measured airblast pressure data (underground and free-field) were consistent and indicated a complete detonation of the explosive charge. The ground motion data from integrated acceleration-time histories in the vertical bore hole are in good agreement with data from previous UAST detonations at this site. Comparison of these data and the surface motion values show that both data sets attenuate at the rate $R_{s}^{-2.5}$. The surface motion reflection factor was slightly greater than the theoretical free-surface value, but was in good agreement with reflection factors of 3 to 5 that have been observed on underground nuclear tests.

\section{Recommendations}

The aim of underground ammunition storage research to date has been reduction of external airblast and debris hazards from accidental detonations. The ground shock hazard distances were secondary until these hazards were significantly reduced. Underground ammunition storage facilities designed for use in Singapore must also consider reduction in ground shock hazards. Therefore, a comprehensive ground motion research program is needed to evaluate the ground shock hazards at the proposed site in Singapore. The study should evaluate the effects of decoupled detonations and shock isolation techniques on ground shock hazards. 


\section{References}

L. K. Davis. (1995). "Explosive Hazard Analysis For Design of Underground Magazines," Research Proposal submitted to the Republic of Singapore, Ministry of Defence, by U.S. Army Engineer Waterways Experiment Station, Vicksburg, MS.

J. Wesley Martin. (1994). "Material Characterization of Samples from the Linchburg Mine," TeraTek, Inc., Salt Lake City, UT. 


\section{Appendix A 1996 Singapore Ground Shock Time-Histories}

Acceleration-, Particle Velocity- and Displacement-Time Histories from the Detonation of $696.6 \mathrm{~kg}$ of Composition B Explosive 


\section{REPUBLIC OF SINGAPORE GROUND SHOCK TEST \\ TDR001, Gage 204A, 4 m \\ Linchburg Mine, Magdalena, NM}

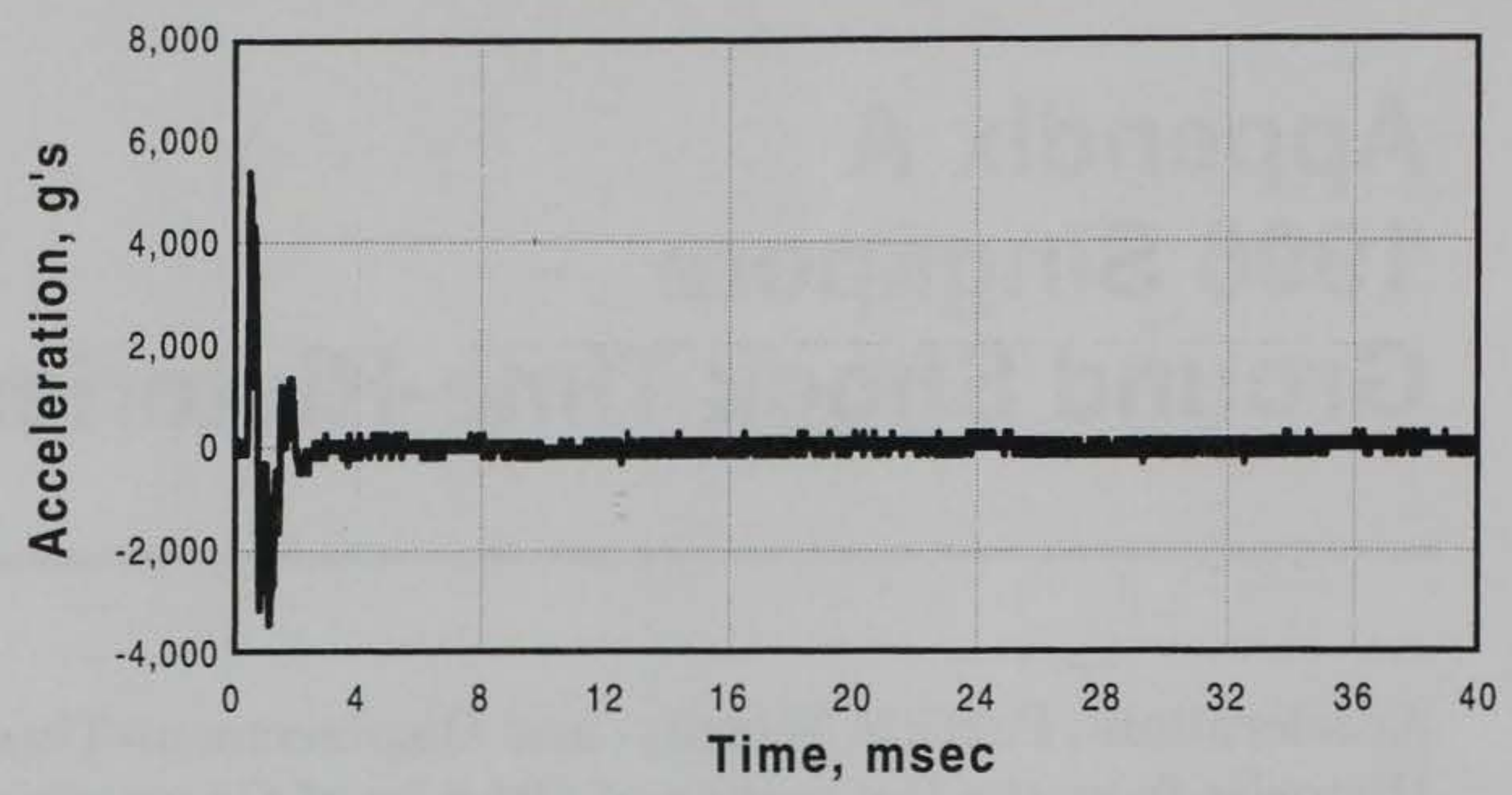

\section{REPUBLIC OF SINGAPORE GROUND SHOCK TEST}

TDR001, Gage 204A, $4 \mathrm{~m}$

Linchburg Mine, Magdalena, NM

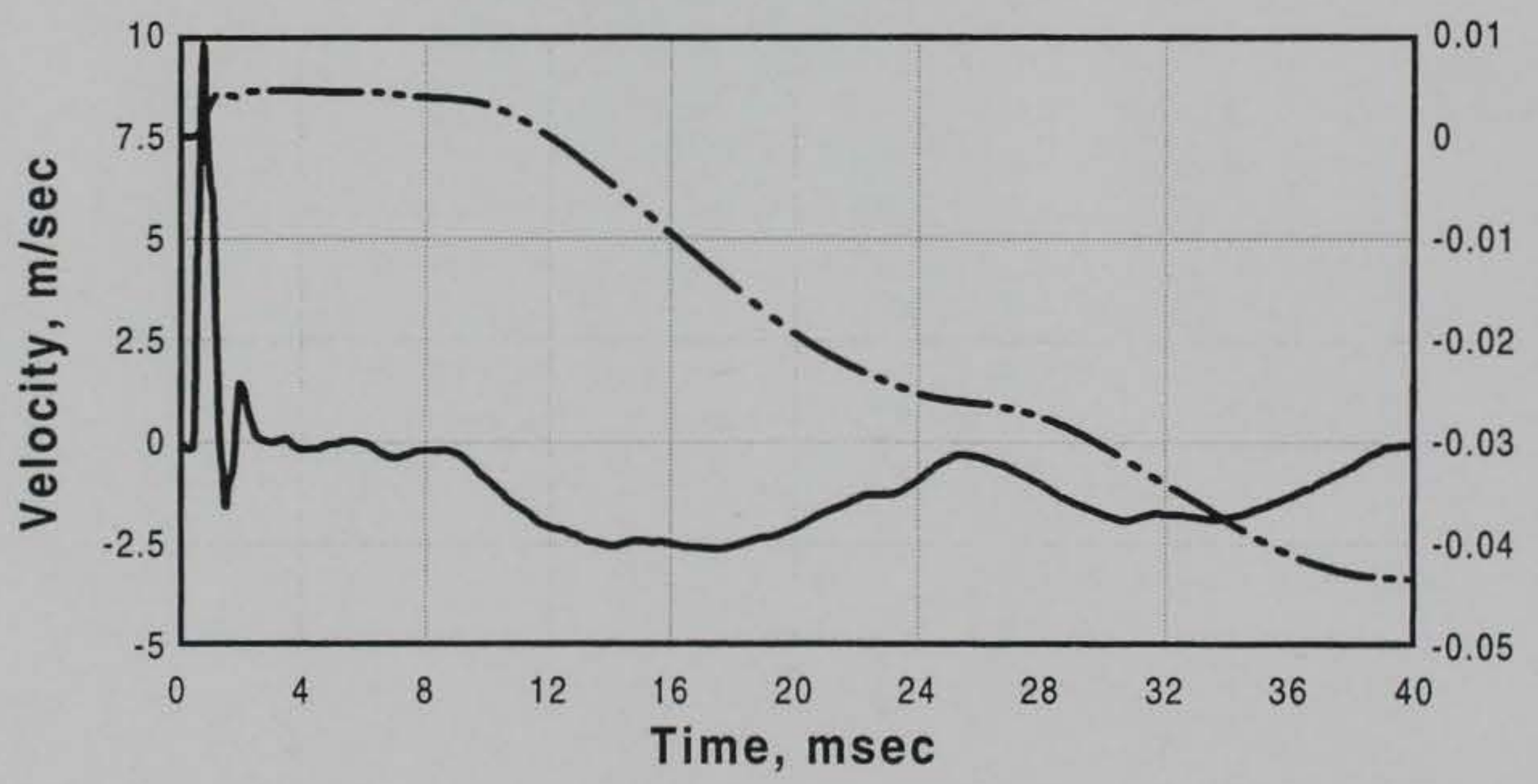

$E$
Eี
E
$\frac{0}{0}$
$\frac{\pi}{0}$
$\frac{0}{0}$

Figure A1. Vertical ground motion: acceleration-, velocity-, and displacement-time histories at Station 204A, $4 \mathrm{~m}$ from the center of Chamber 2, Singapore Ground Shock Test. 


\section{REPUBLIC OF SINGAPORE GROUND SHOCK TEST \\ TDR002, Gage 204B, $4 \mathrm{~m}$ \\ Linchburg Mine, Magdalena, NM}

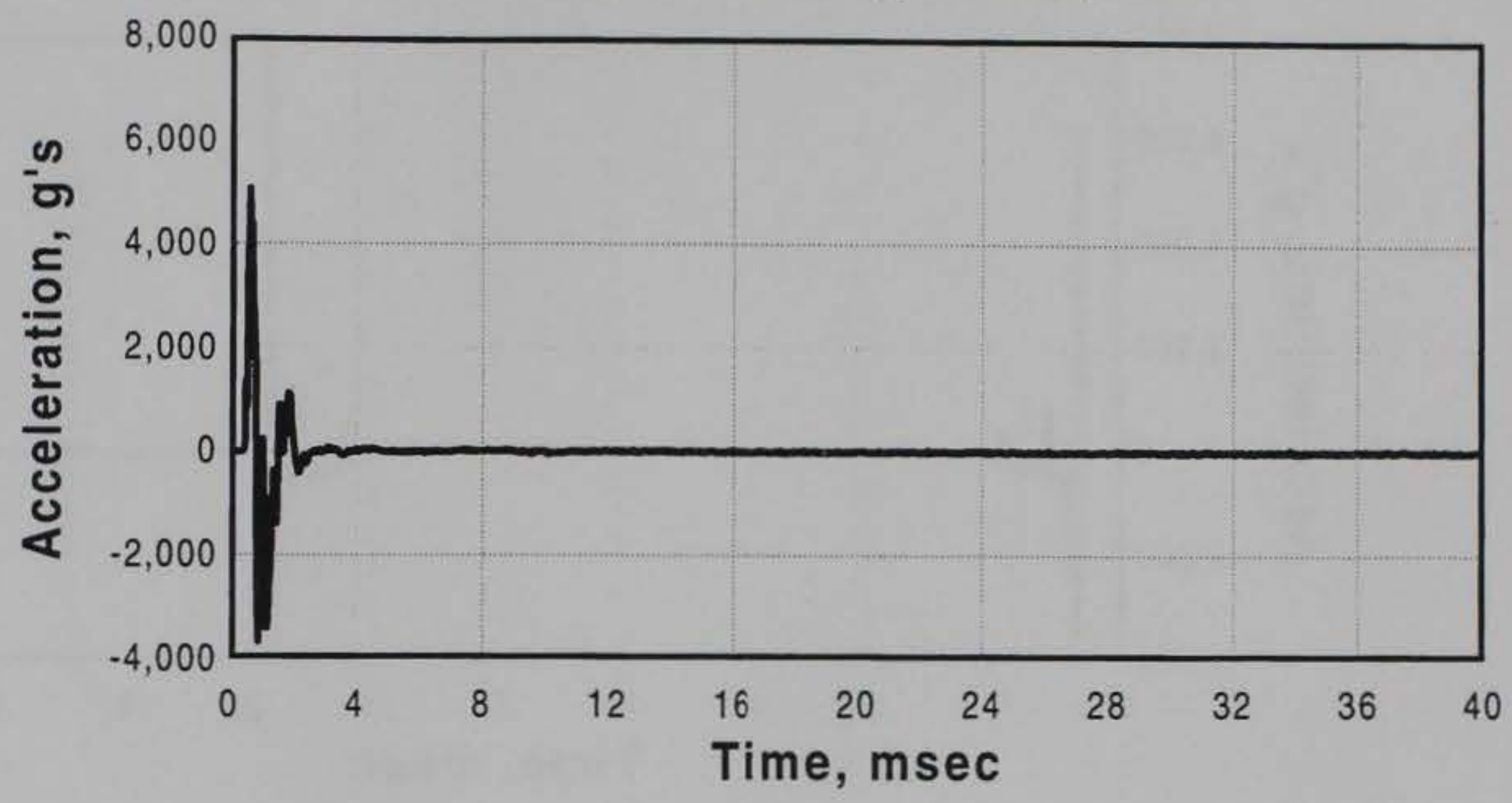

REPUBLIC OF SINGAPORE GROUND SHOCK TEST

TDR002, Gage 204B, $4 \mathrm{~m}$

Linchburg Mine, Magdalena, NM

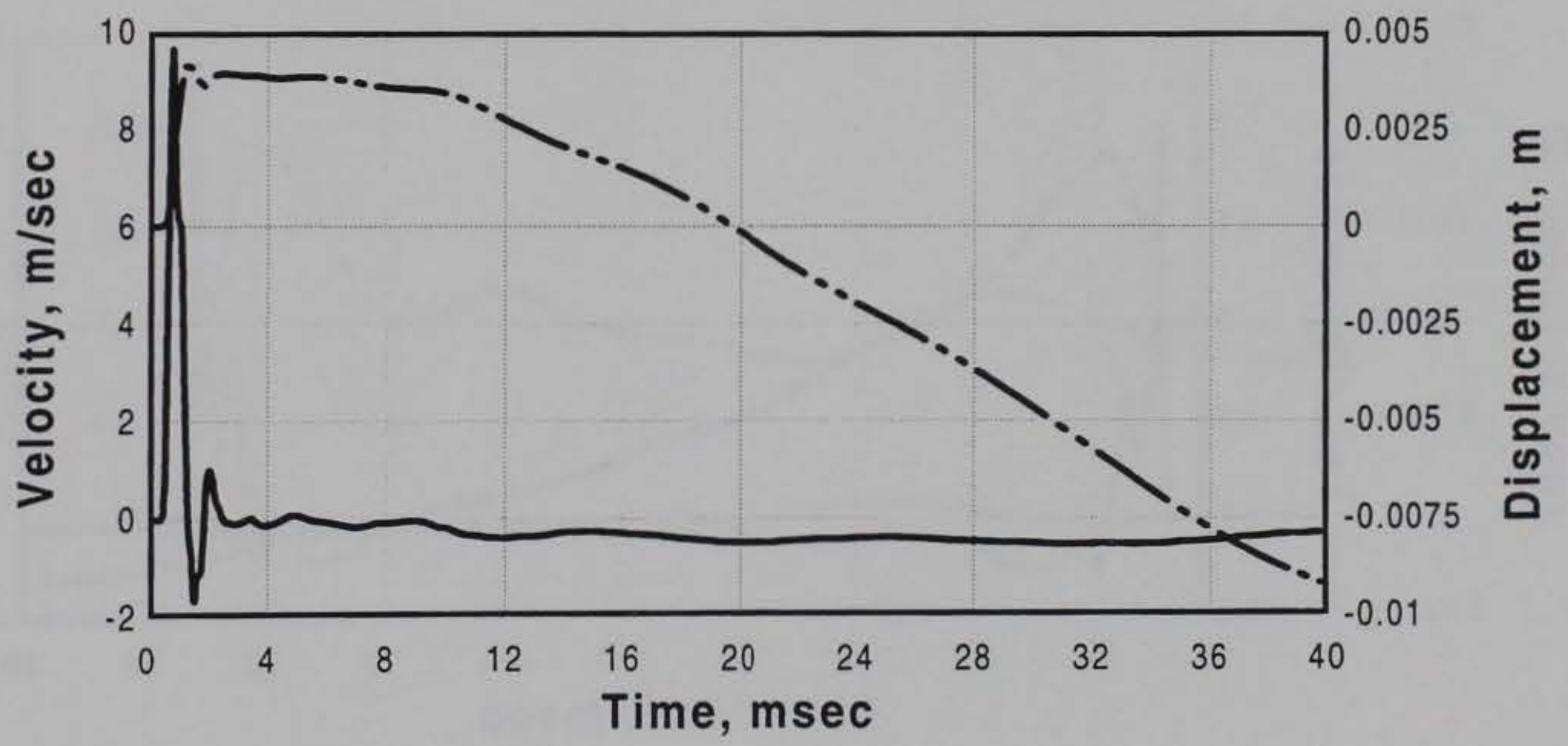

Figure A2. Vertical ground motion: acceleration-, velocity-, and displacement-time histories at Station 204B, $4 \mathrm{~m}$ from the center of Chamber 2, Singapore Ground Shock Test. 


\section{REPUBLIC OF SINGAPORE GROUND SHOCK TEST \\ TDR003, Gage 208A, $8 \mathrm{~m}$ \\ Linchburg Mine, Magdalena, NM}

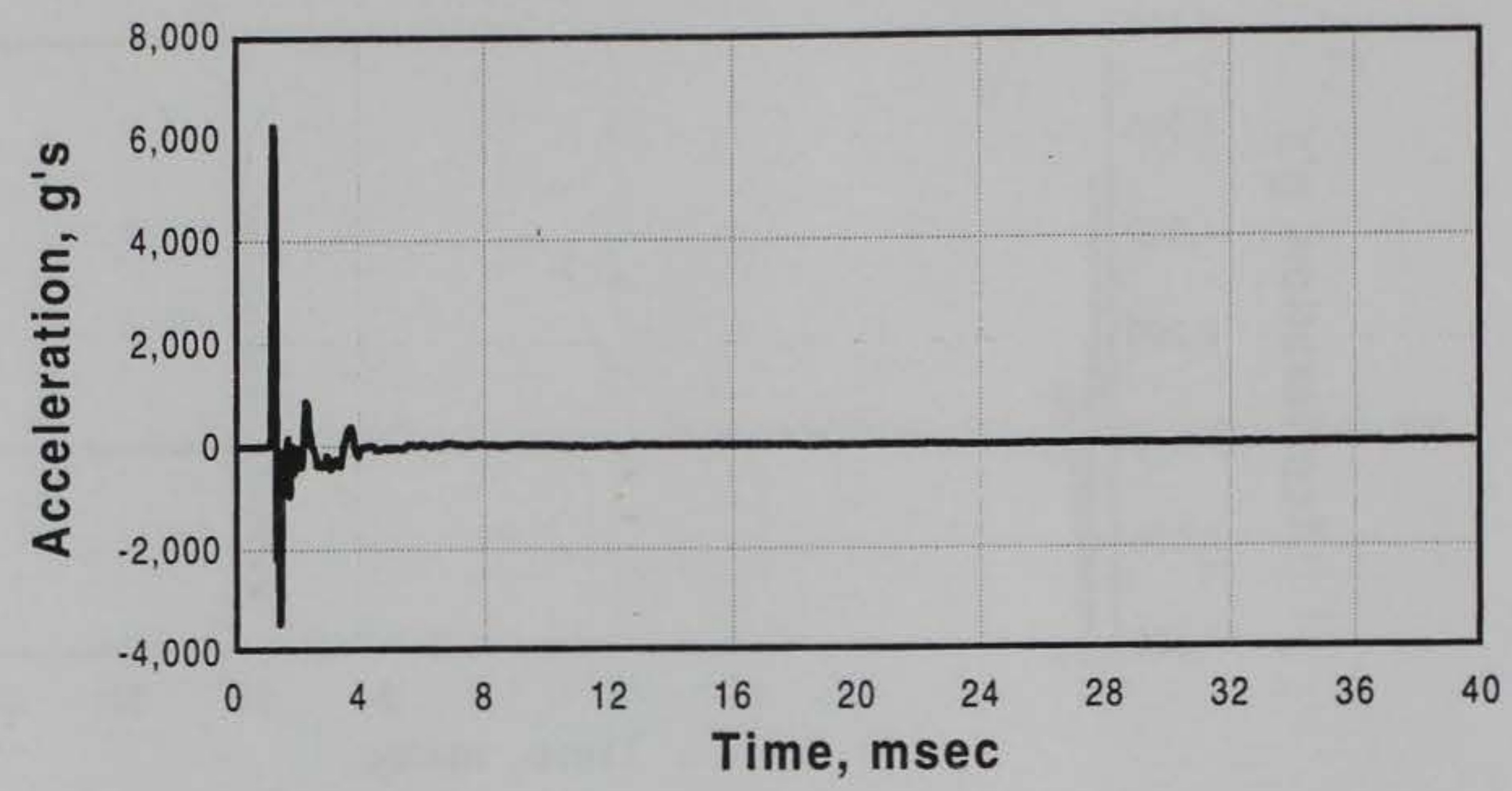

\section{REPUBLIC OF SINGAPORE GROUND SHOCK TEST \\ TDR003, Gage 208A, $8 \mathrm{~m}$ \\ Linchburg Mine, Magdalena, NM}

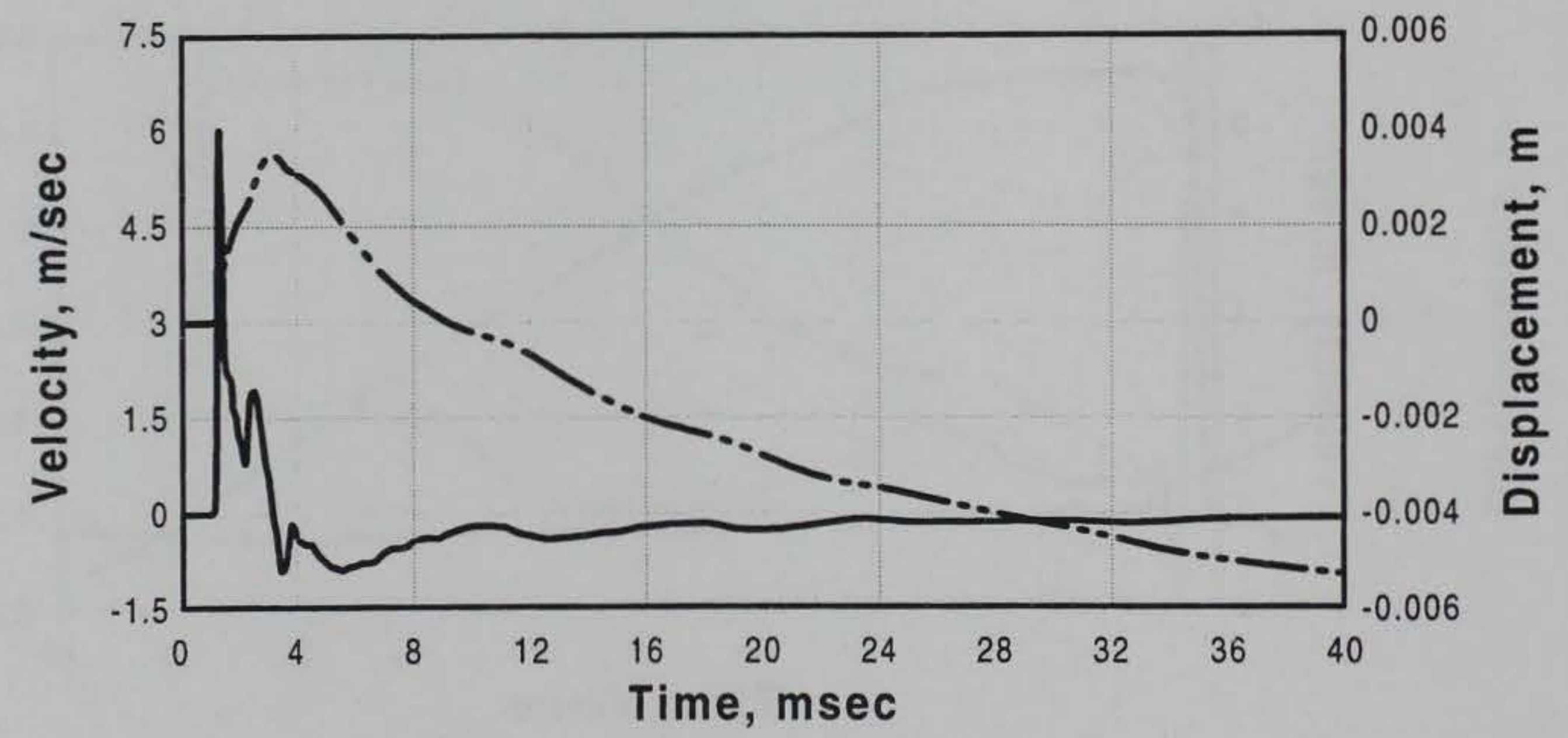

Figure A3. Vertical ground motion: acceleration-, velocity-, and displacement-time histories at Station 208A, $8 \mathrm{~m}$ from the center of Chamber 2, Singapore Ground Shock Test. 


\section{REPUBLIC OF SINGAPORE GROUND SHOCK TEST \\ TDR004, Gage 208B, $8 \mathrm{~m}$ \\ Linchburg Mine, Magdalena, NM}

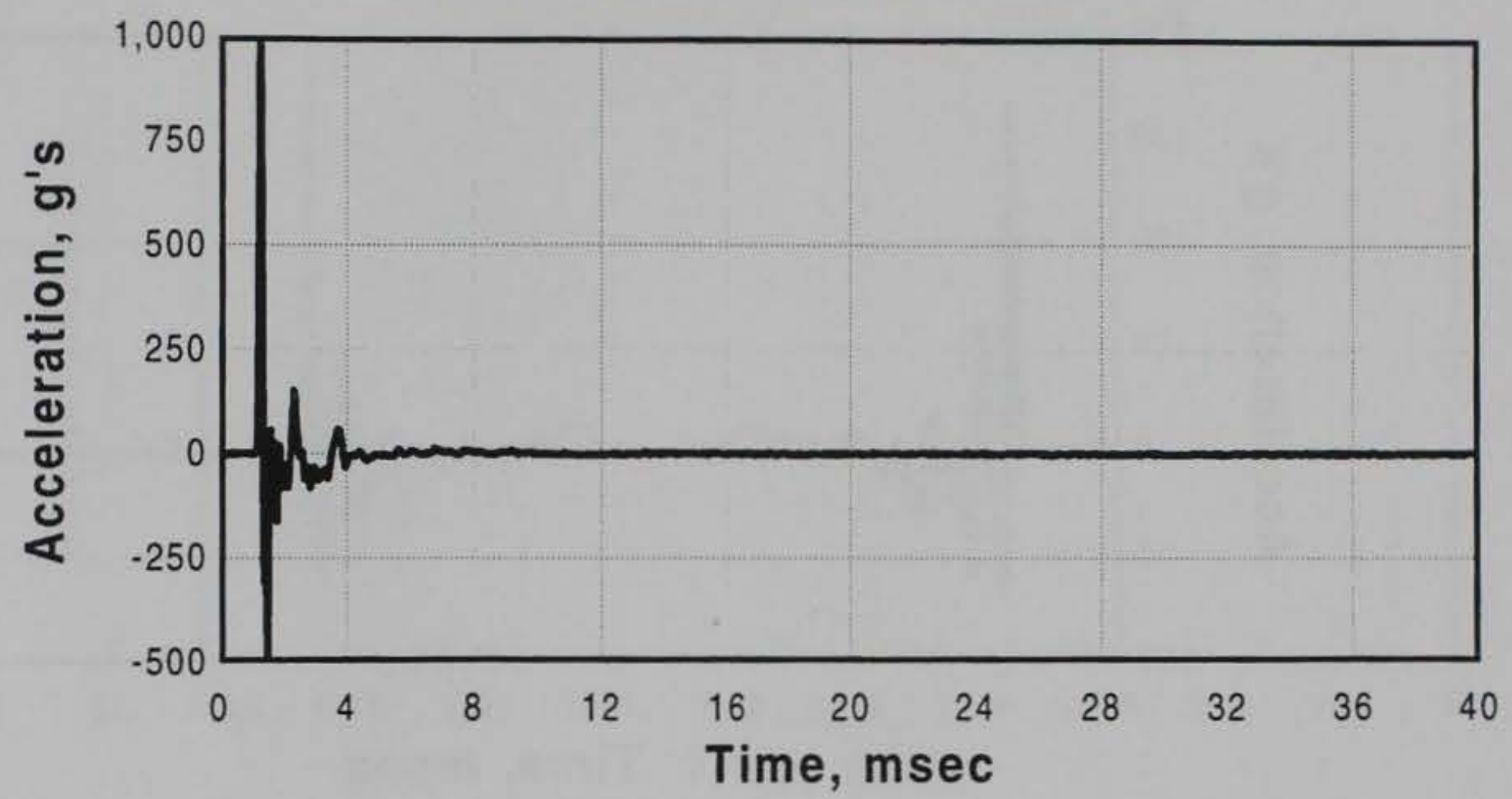

REPUBLIC OF SINGAPORE GROUND SHOCK TEST

TDR004, Gage 208B, $8 \mathrm{~m}$

Linchburg Mine, Magdalena, NM

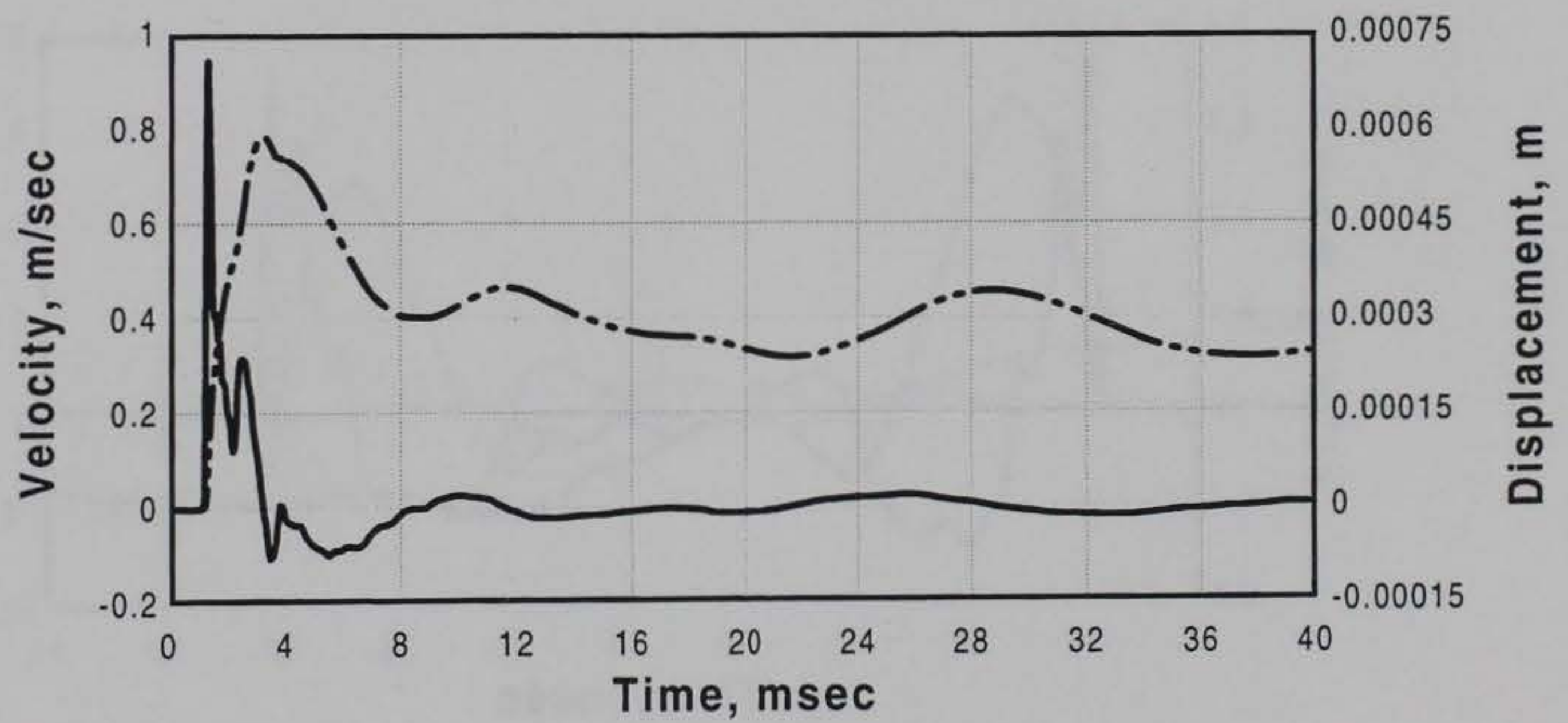

Figure A4. Vertical ground motion: acceleration-, velocity-, and displacement-time histories at Station 208B, $8 \mathrm{~m}$ from the center of Chamber 2, Singapore Ground Shock Test. 


\section{REPUBLIC OF SINGAPORE GROUND SHOCK TEST \\ TDR005, Gage 216A, $16 \mathrm{~m}$ \\ Linchburg Mine, Magdalena, NM}

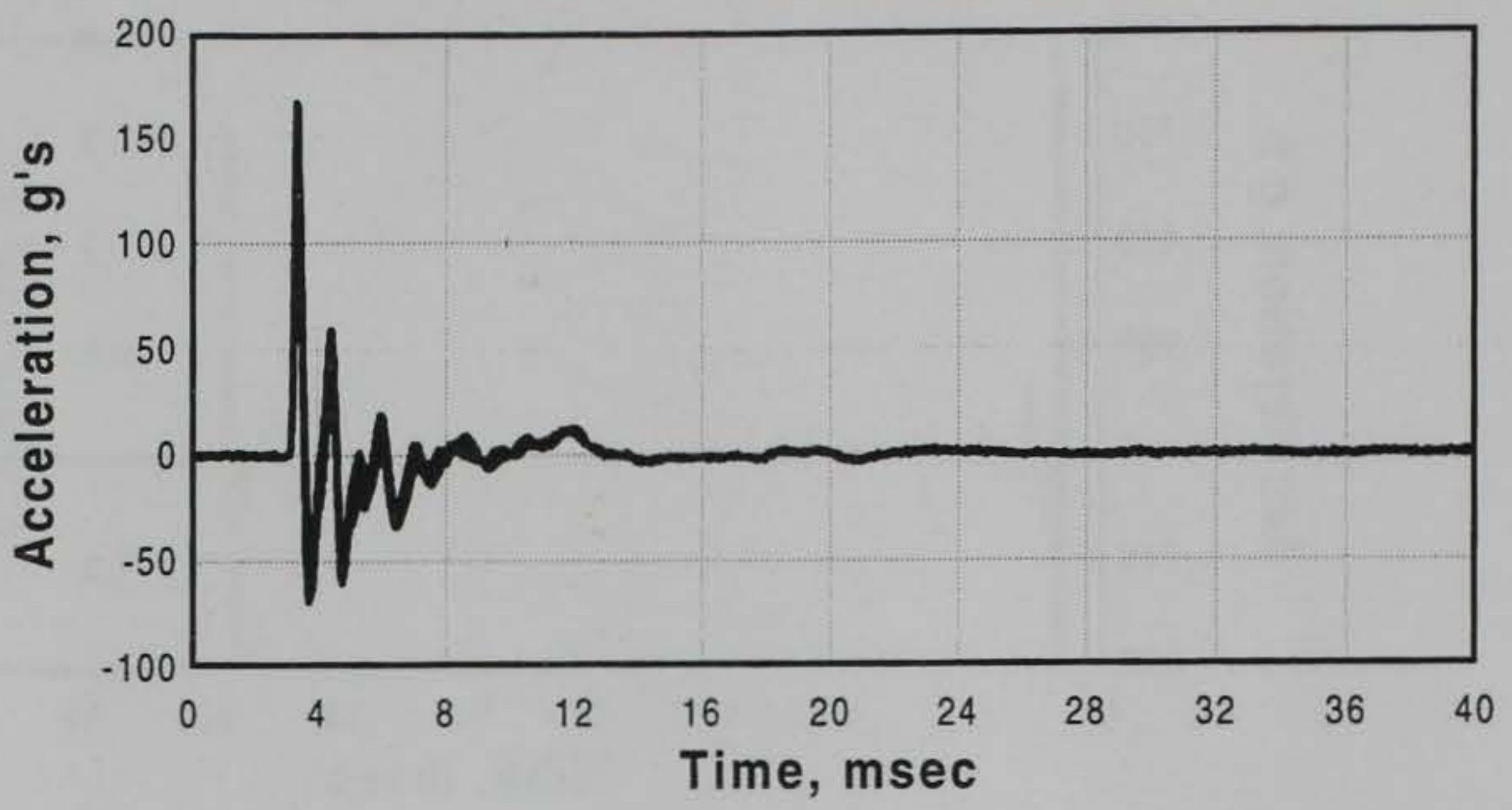

\section{REPUBLIC OF SINGAPORE GROUND SHOCK TEST TDR005, Gage 216A, $16 \mathrm{~m}$ \\ Linchburg Mine, Magdalena, NM}

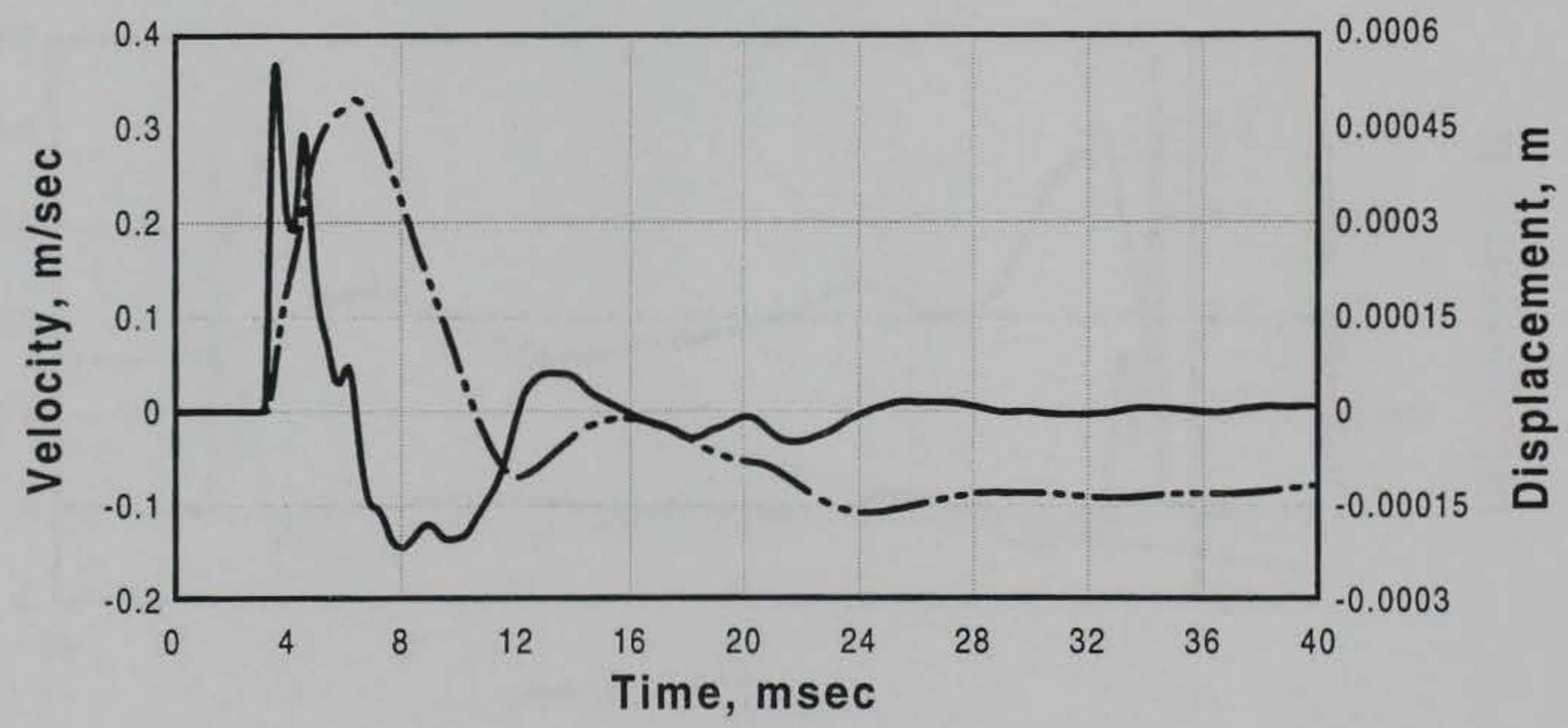

Figure A5. Vertical ground motion: acceleration-, velocity-, and displacement-time histories at Station 216A, $16 \mathrm{~m}$ from the center of Chamber 2, Singapore Ground Shock Test. 


\section{REPUBLIC OF SINGAPORE GROUND SHOCK TEST \\ TDR006, Gage 216B, $16 \mathrm{~m}$ \\ Linchburg Mine, Magdalena, NM}

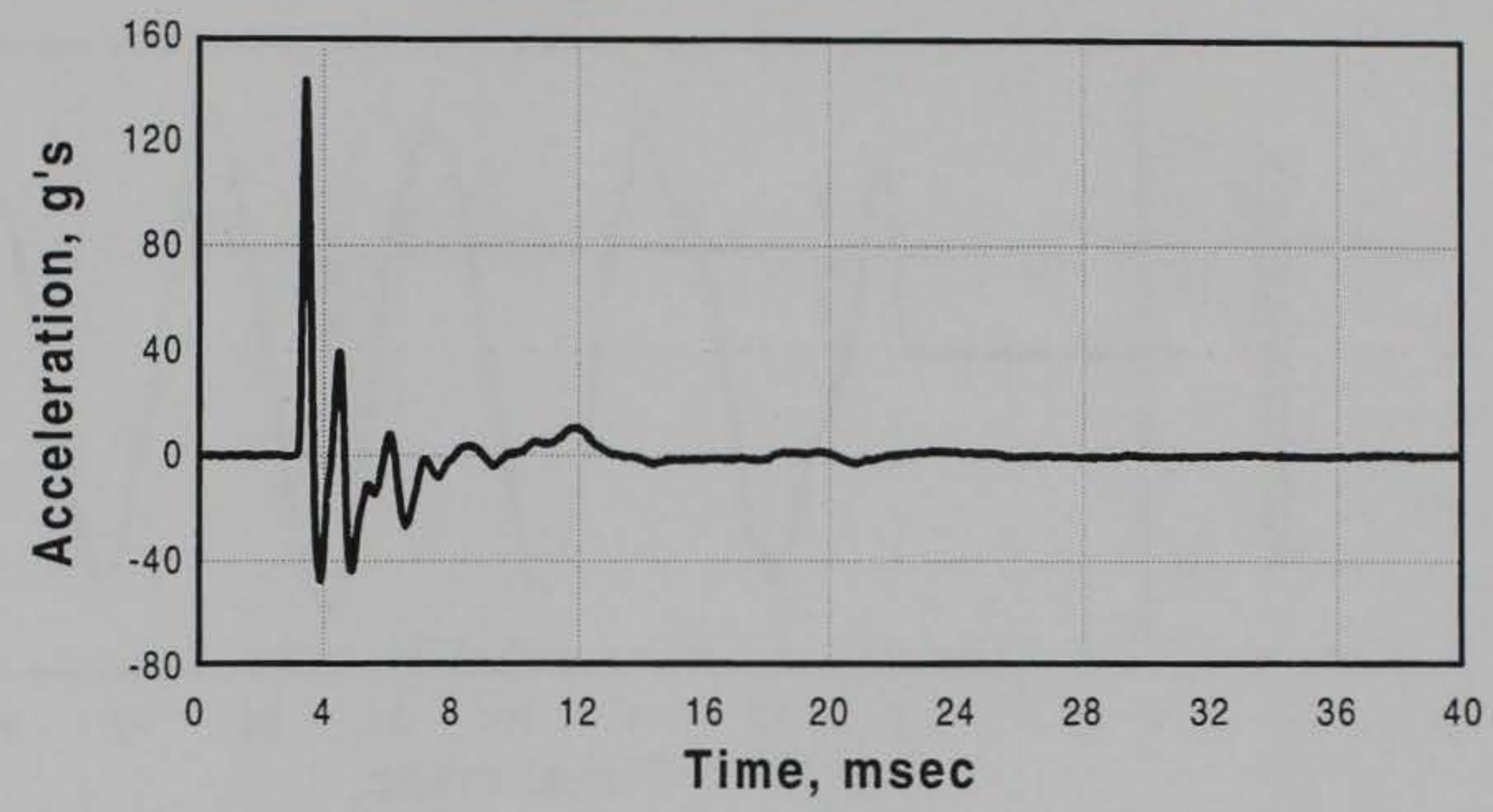

\section{REPUBLIC OF SINGAPORE GROUND SHOCK TEST TDR006, Gage 216B, $16 \mathrm{~m}$ Linchburg Mine, Magdalena, NM}

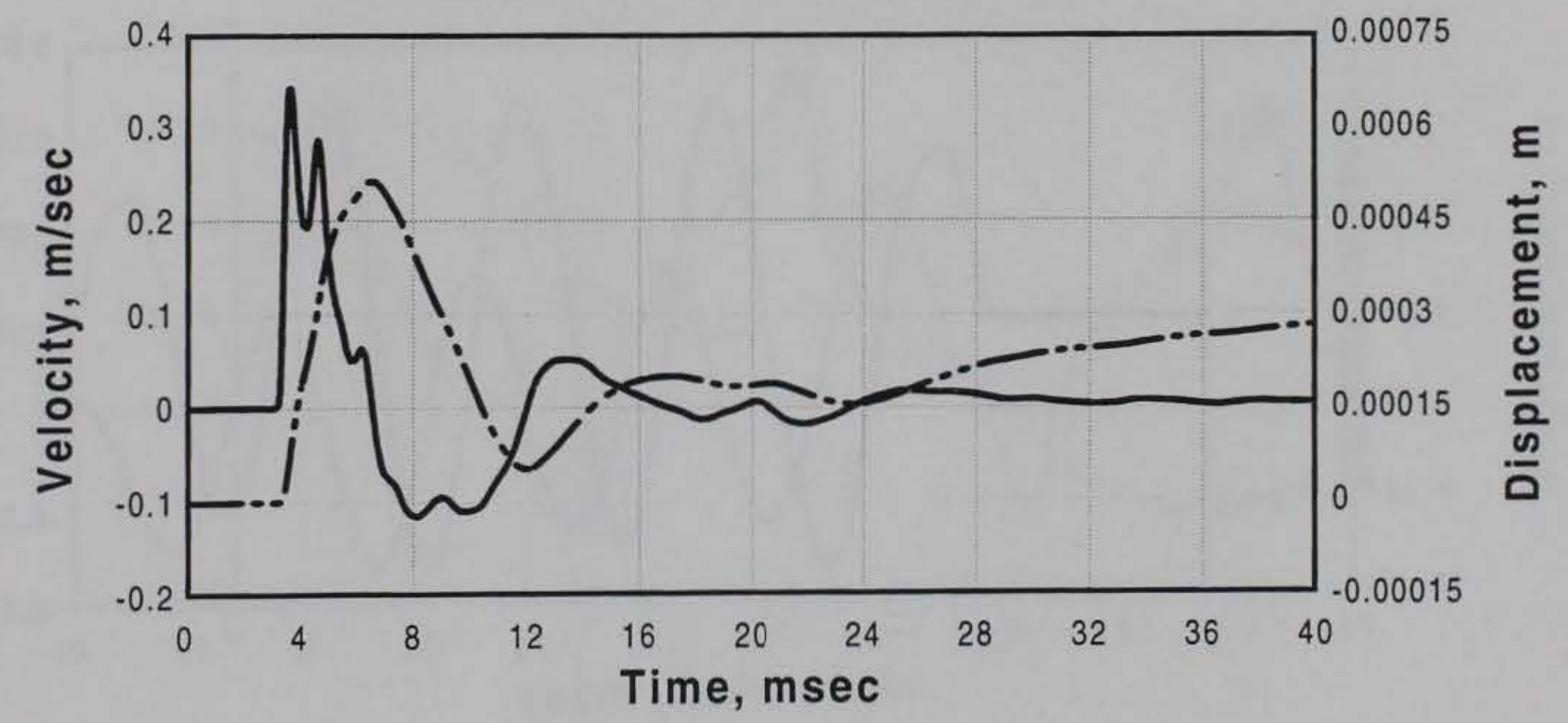

Figure A6. Vertical ground motion: acceleration-, velocity-, and displacement-time histories at Station 216B, $16 \mathrm{~m}$ from the center of Chamber 2, Singapore Ground Shock Test. 


\section{REPUBLIC OF SINGAPORE GROUND SHOCK TEST \\ TDR007, Gage 232A, $32 \mathrm{~m}$ \\ Linchburg Mine, Magdalena, NM}

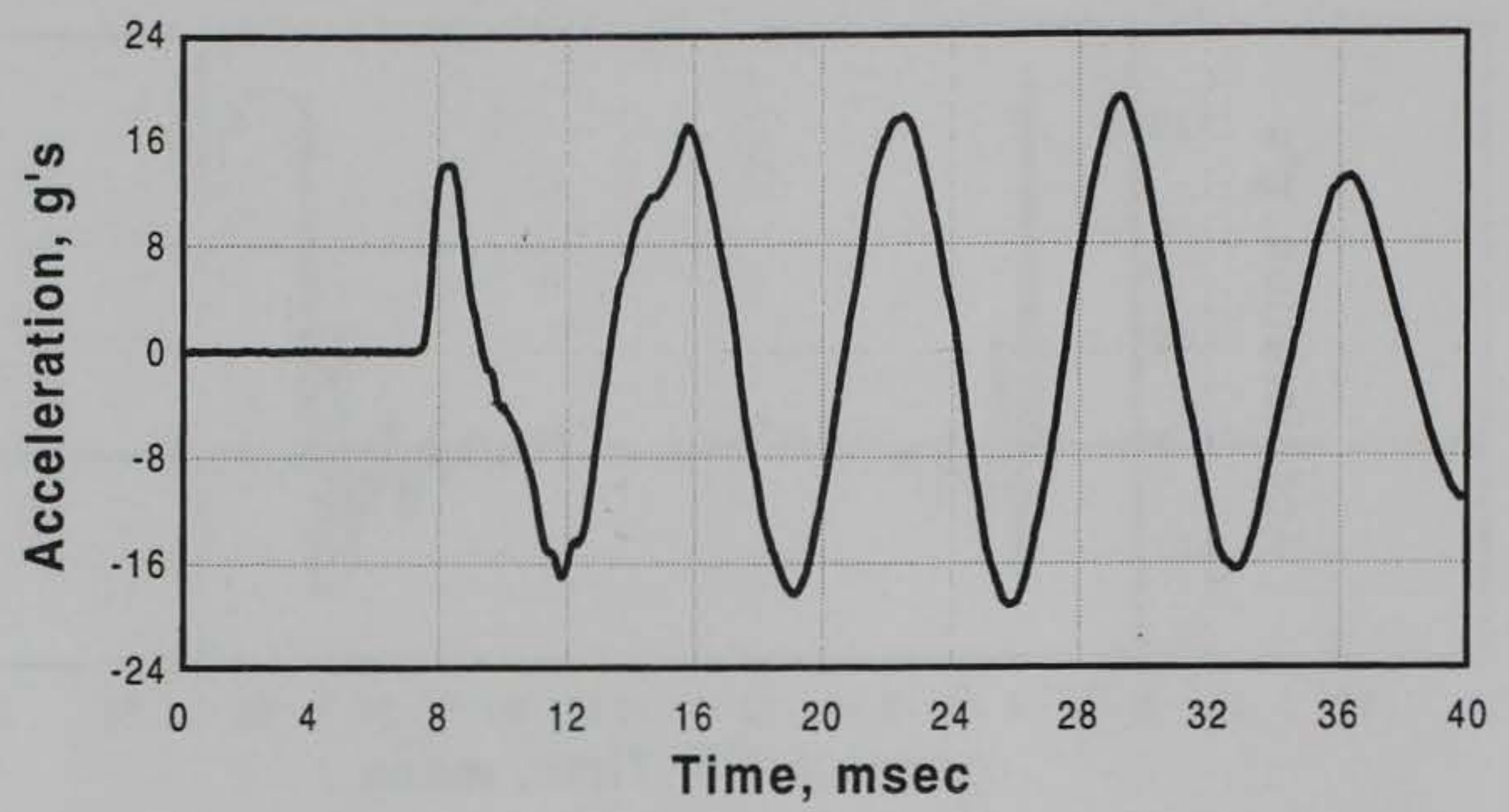

\section{REPUBLIC OF SINGAPORE GROUND SHOCK TEST \\ TDR007, Gage 232A, $32 \mathrm{~m}$ \\ Linchburg Mine, Magdalena, NM}

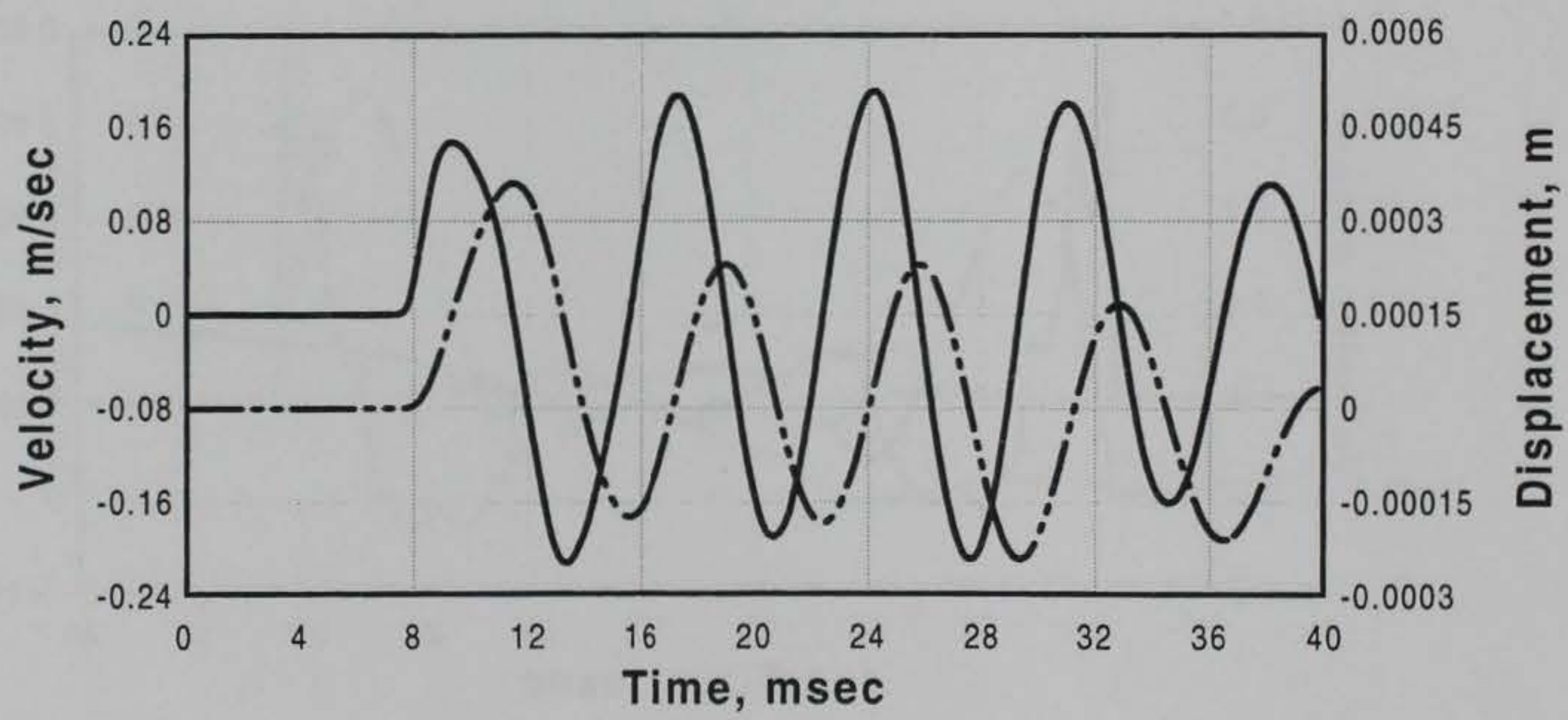

Figure A7. Vertical ground motion: acceleration-, velocity-, and displacement-time histories at Station 232A, $32 \mathrm{~m}$ from the center of Chamber 2, Singapore Ground Shock Test. 


\section{REPUBLIC OF SINGAPORE GROUND SHOCK TEST \\ TDR008, Gage 232B, $32 \mathrm{~m}$ \\ Linchburg Mine, Magdalena, NM}

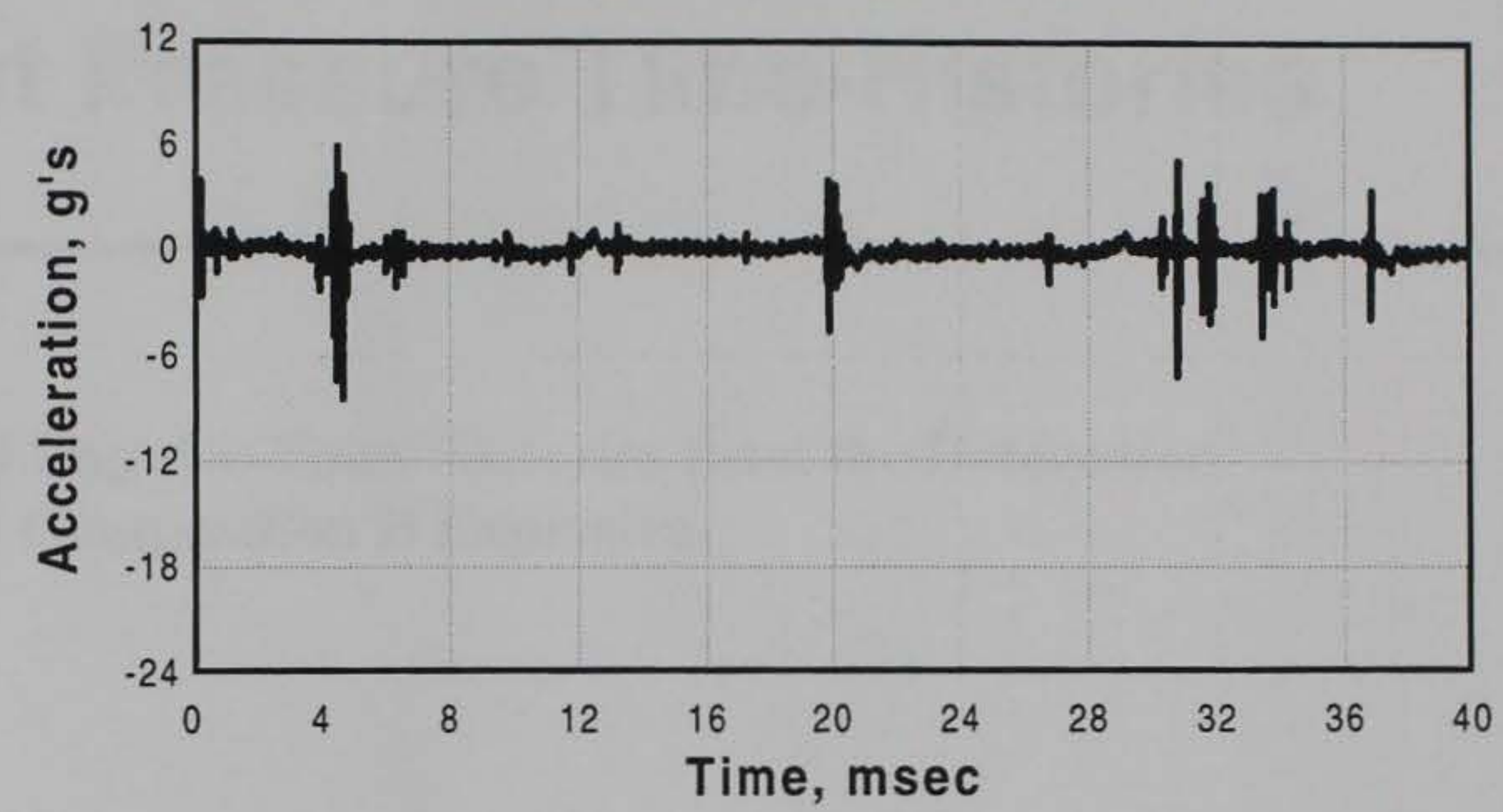

\section{REPUBLIC OF SINGAPORE GROUND SHOCK TEST \\ TDR008, Gage 232B, $32 \mathrm{~m}$ \\ Linchburg Mine, Magdalena, NM}

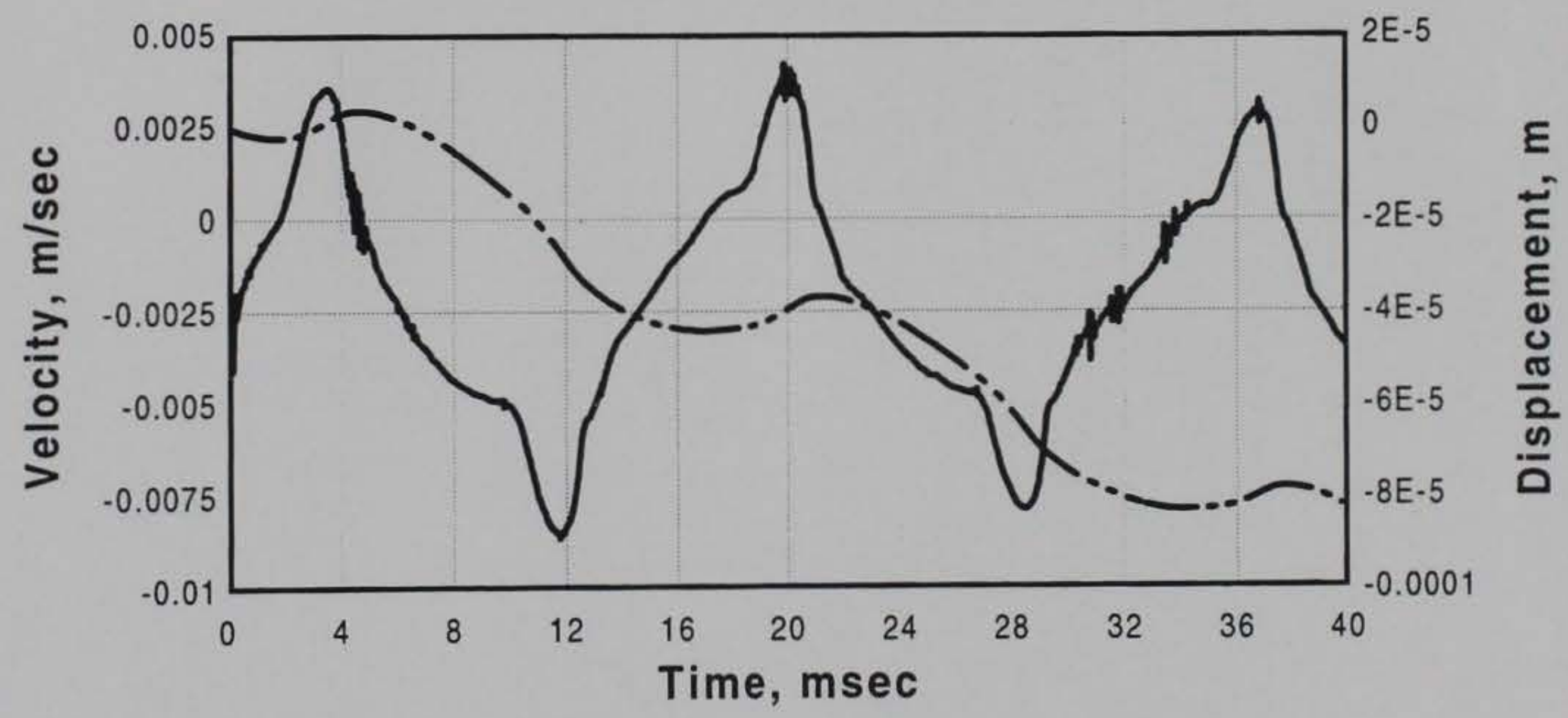

Figure A8. Vertical ground motion: acceleration-, velocity-, and displacement-time histories at Station 232B, $32 \mathrm{~m}$ from the center of Chamber 2, Singapore Ground Shock Test. 


\section{Appendix B}

\section{Singapore Ground Shock Test: Airblast Pressure Time-Histories}

Pressure- and Impulse-Time-Histories from the Detonation of $696.6 \mathrm{~kg}$ of Composition B Explosive 


\section{$20 A B S O$ REPUBLIC OF SINGAPORE GROUND SHOCK TEST} 06-18-1996 02:00:35

Cal val $=2069.451, \mathrm{CBS}=1.0181$

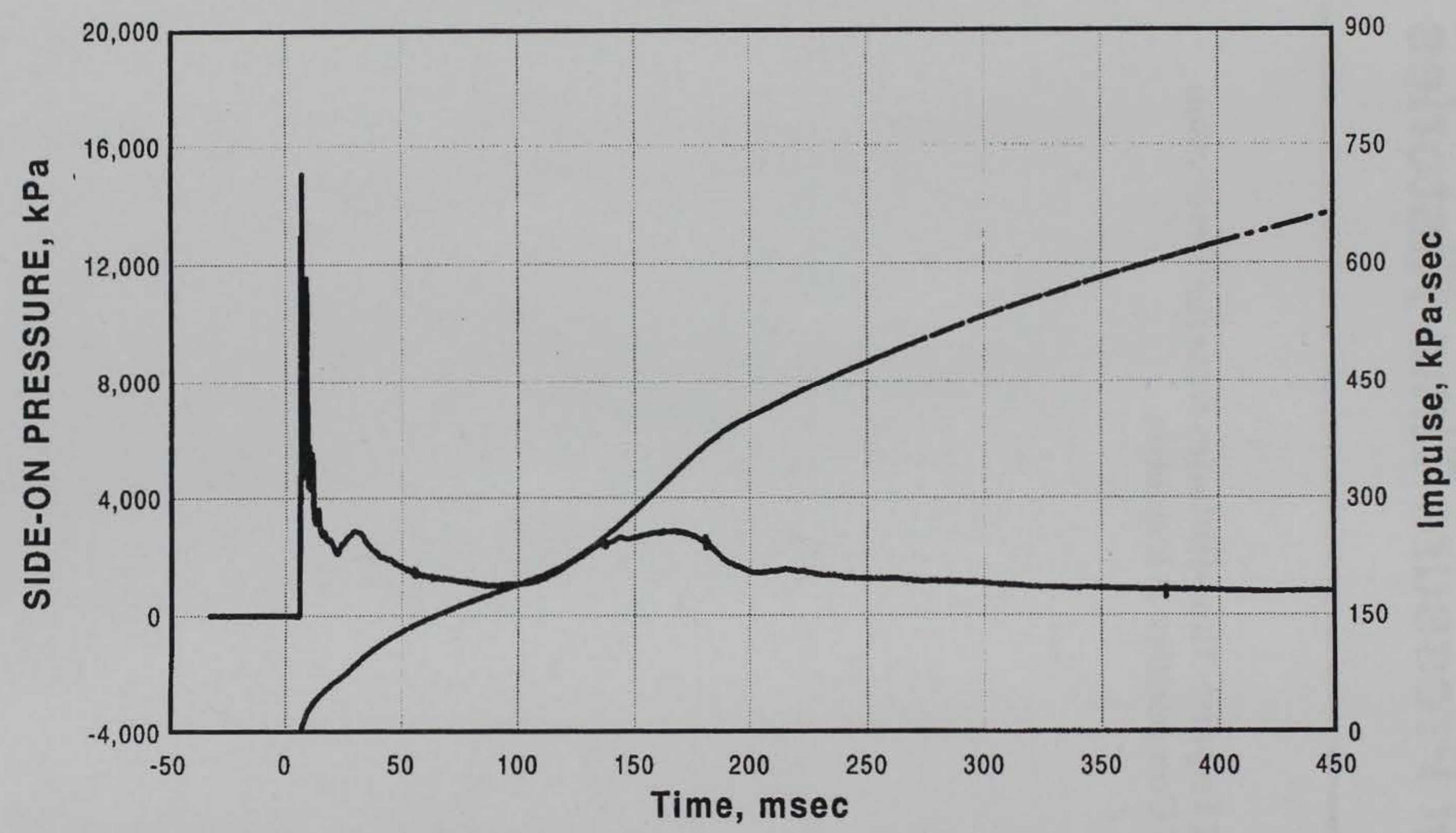

Figure B1. Gage 20ABSO airblast overpressure- and impulse-time-histories (450 $\mathrm{msec}$ record), Singapore Ground Shock Test. 


\section{ABSO REPUBLIC OF SINGAPORE GROUND SHOCK TEST}

06-18-1996 02:00:35

Cal val $=2069.451$, CBS $=1.0181$

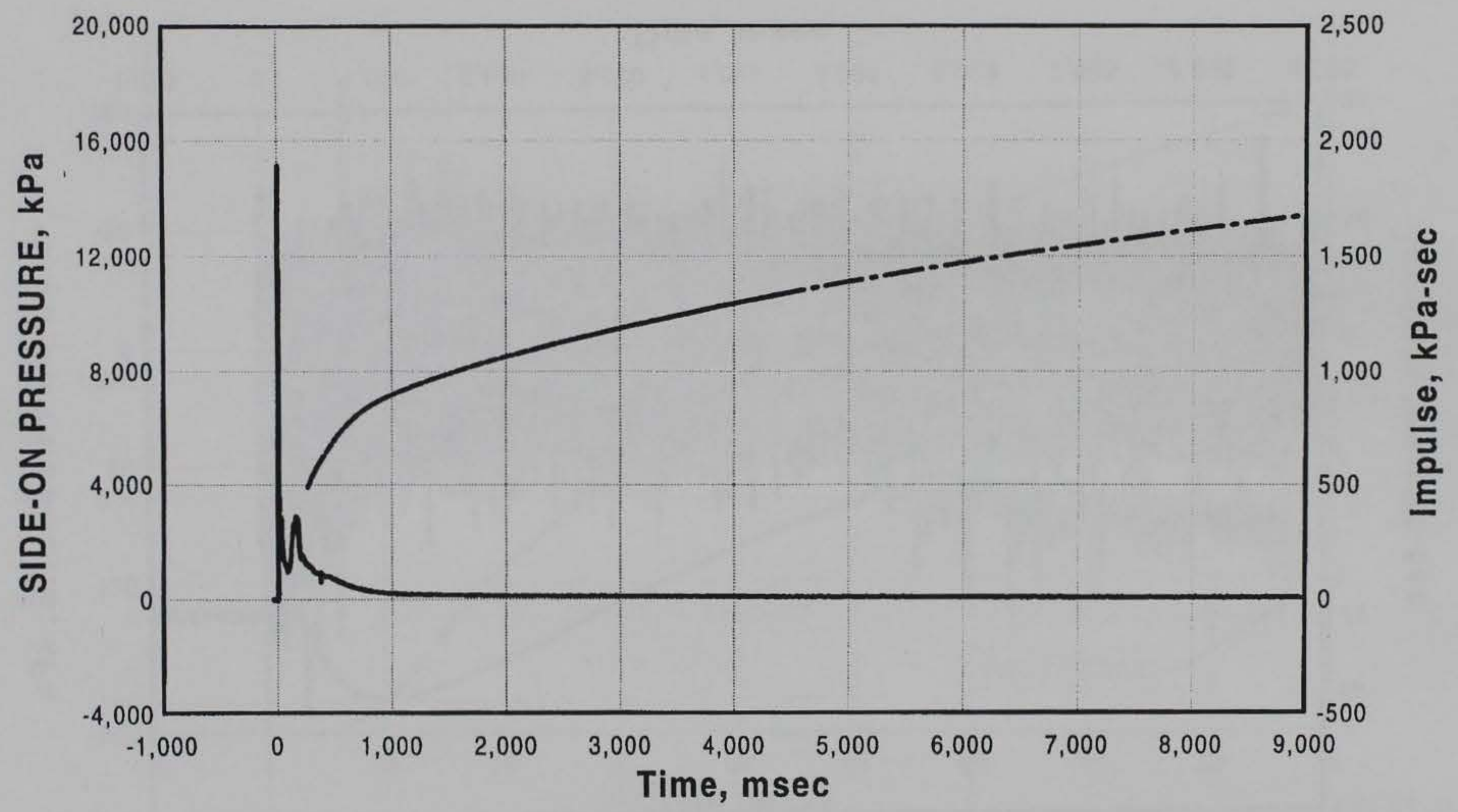

Figure B2. Gage 20ABSO airblast overpressure- and impulse-time-histories (9 sec record), Singapore Ground Shock Test. 
21ABSO REPUBLIC OF SINGAPORE GROUND SHOCK TEST 06-18-1996 02:00:35

Cal val $=1770.29, \mathrm{CBS}=-0.509338$

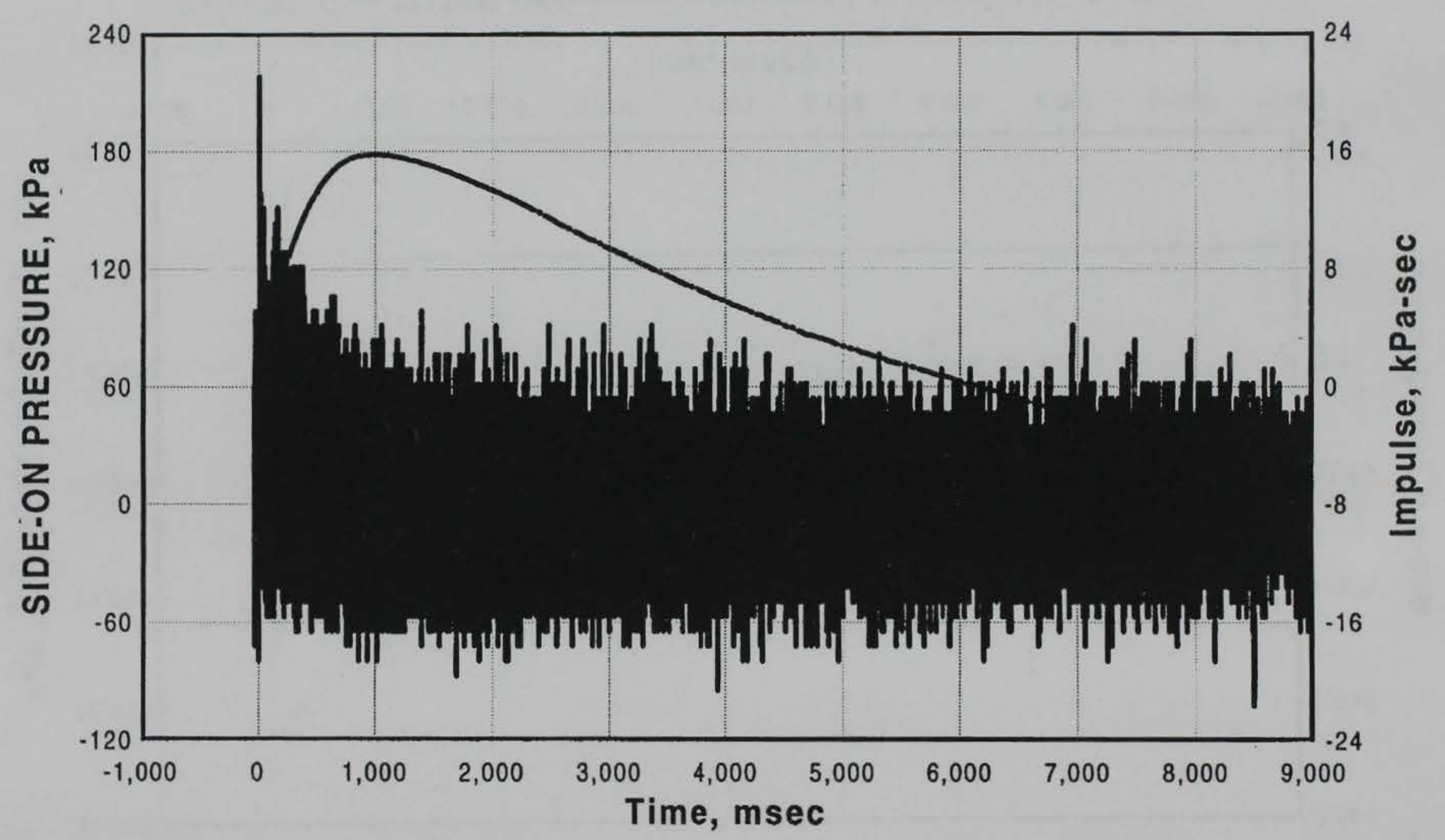

Figure B3. Gage 21ABSO airblast overpressure- and impulse-time-histories (9 sec record), Singapore Ground Shock Test. 


\section{ABSO REPUBLIC OF SINGAPORE GROUND SHOCK TEST 06-18-1996 02:00:35 \\ Cal val $=1132.254, C B S=1.19543$}

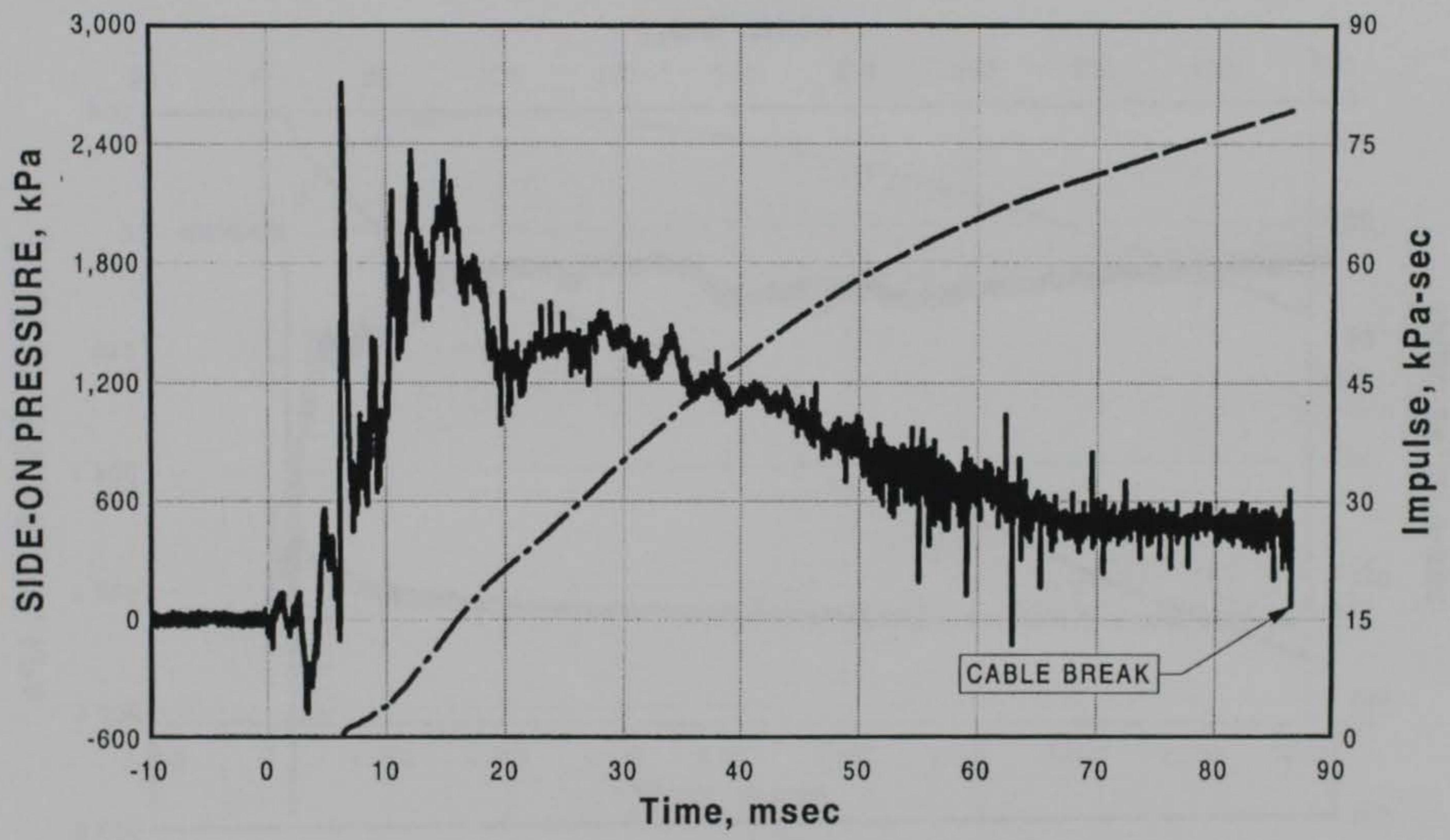

Figure B4. Gage 19ABSO airblast overpressure- and impulse-time-histories (90 msec record), Singapore Ground Shock Test. 


\section{$18 A B S O$ REPUBLIC OF SINGAPORE GROUND SHOCK TEST} 06-18-1996 02:00:35

Cal val $=917.1166, \mathrm{CBS}=0.323935$

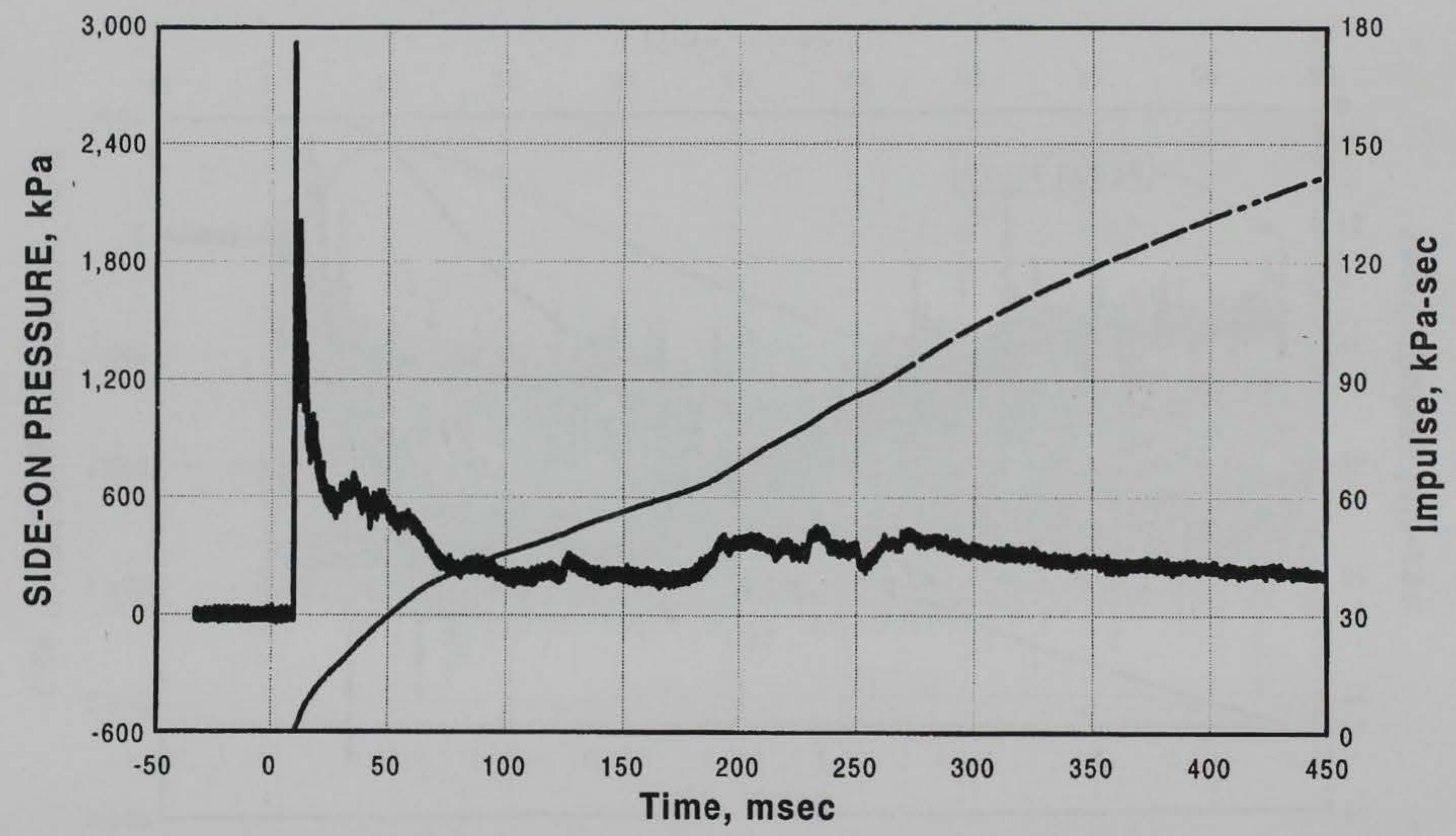

Figure B5. Gage 18ABSO airblast overpressure- and impulse-time-histories (450 msec record), Singapore Ground Shock Test. 
18ABSO REPUBLIC OF SINGAPORE GROUND SHOCK TEST

06-18-1996 02:00:35

Cal val $=917.1166, \mathrm{CBS}=0.323935$

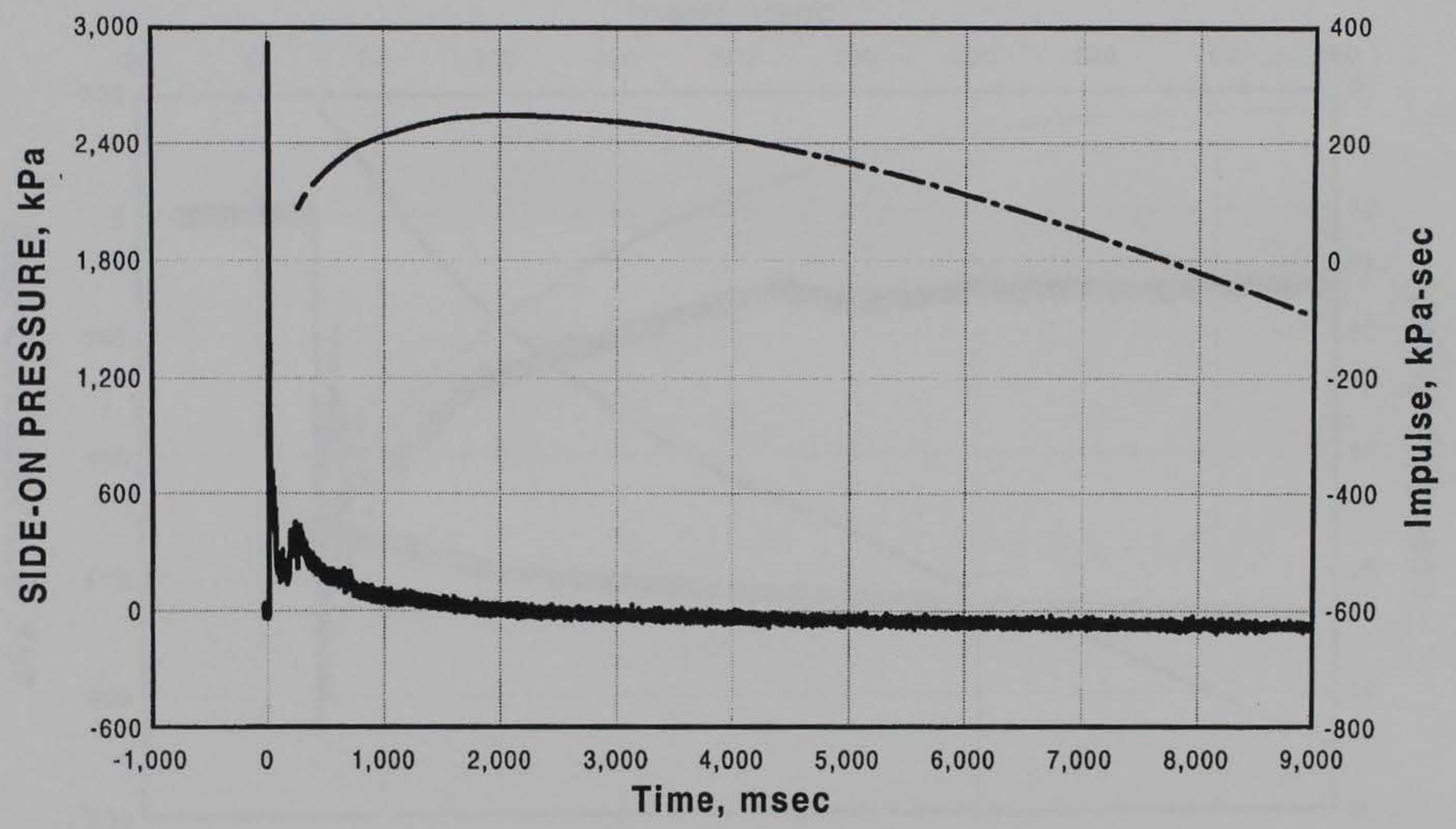

Figure B6. Gage 18ABSO airblast overpressure- and impulse-time-histories (9 sec record), Singapore Ground Shock Test. 
16ABSO REPUBLIC OF SINGAPORE GROUND SHOCK TEST 06-18-1996 02:00:35

Cal val $=388.5679, \mathrm{CBS}=0.000730052$

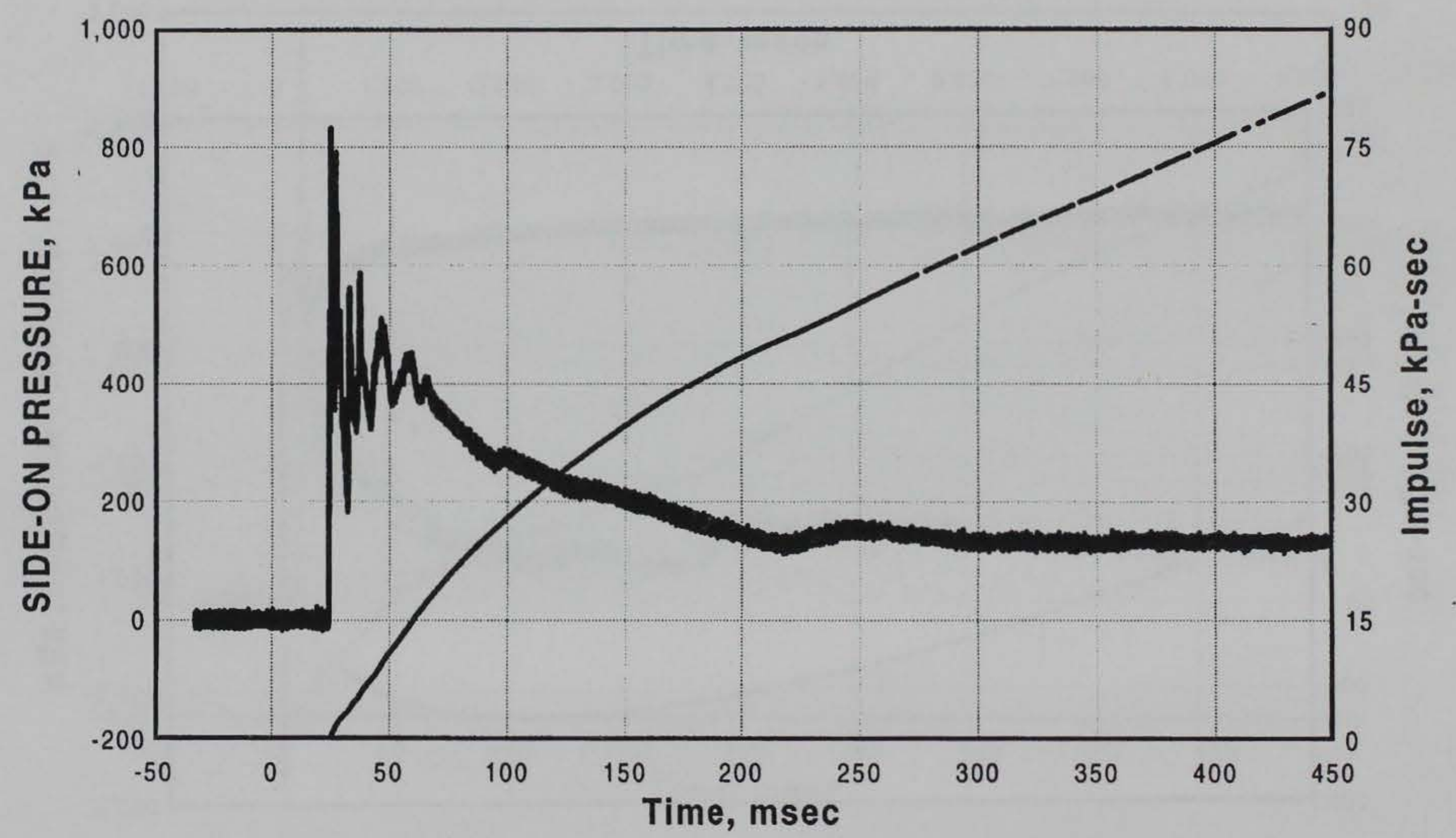

Figure B7. Gage 16ABSO airblast overpressure- and impulse-time-histories (450 msec record), Singapore Ground Shock Test. 


\section{ABSO REPUBLIC OF SINGAPORE GROUND SHOCK TEST}

06-18-1996 02:00:35

Cal val $=388.5679$, CBS $=0.000730052$

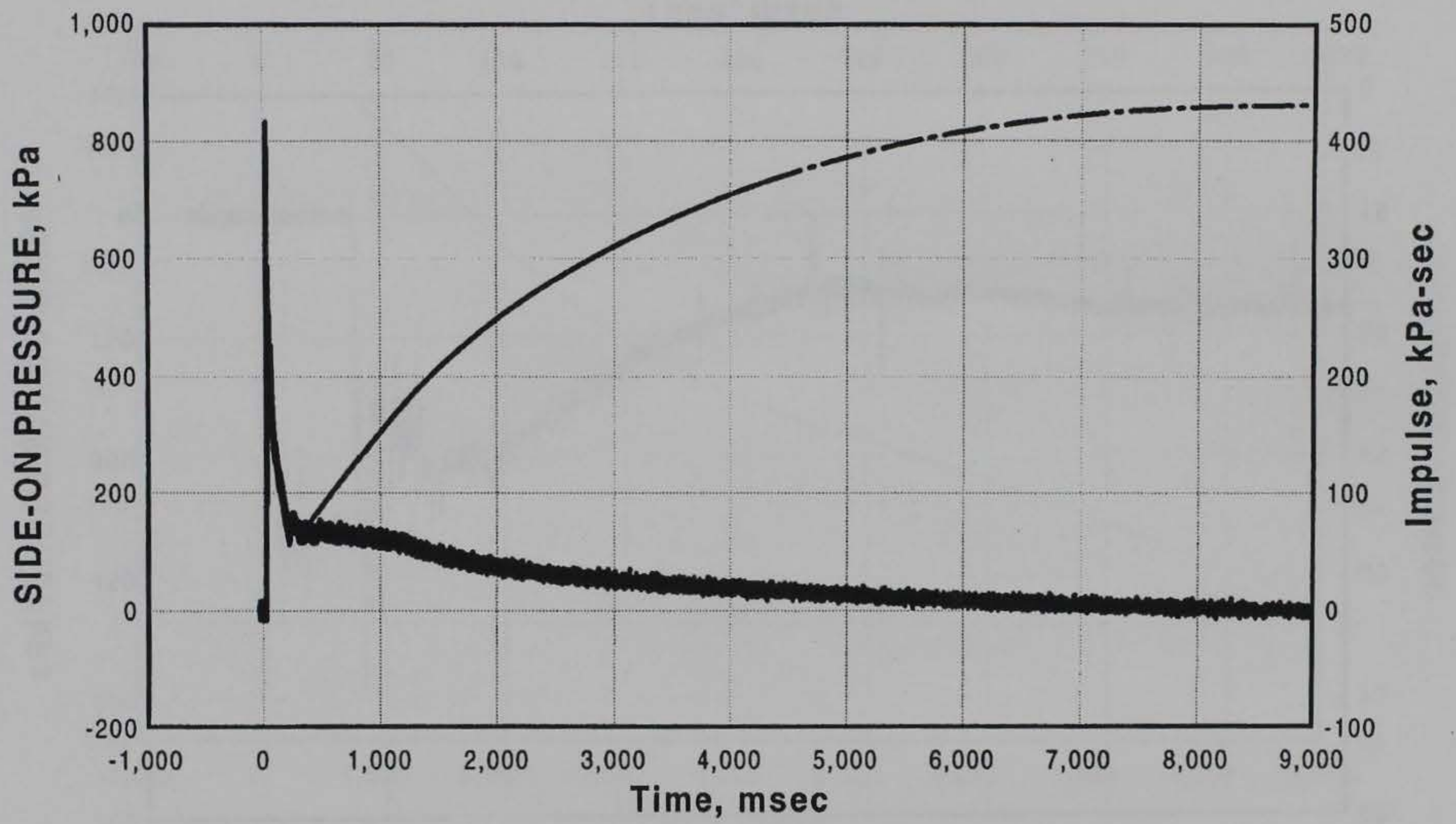

Figure B8. Gage 16ABSO airblast overpressure- and impulse-time-histories ( 9 sec record), Singapore Ground Shock Test. 
11 ABSO REPUBLIC OF SINGAPORE GROUND SHOCK TEST 06-18-1996 02:00:35

Cal val $=250.7745, \mathrm{CBS}=0.290136$

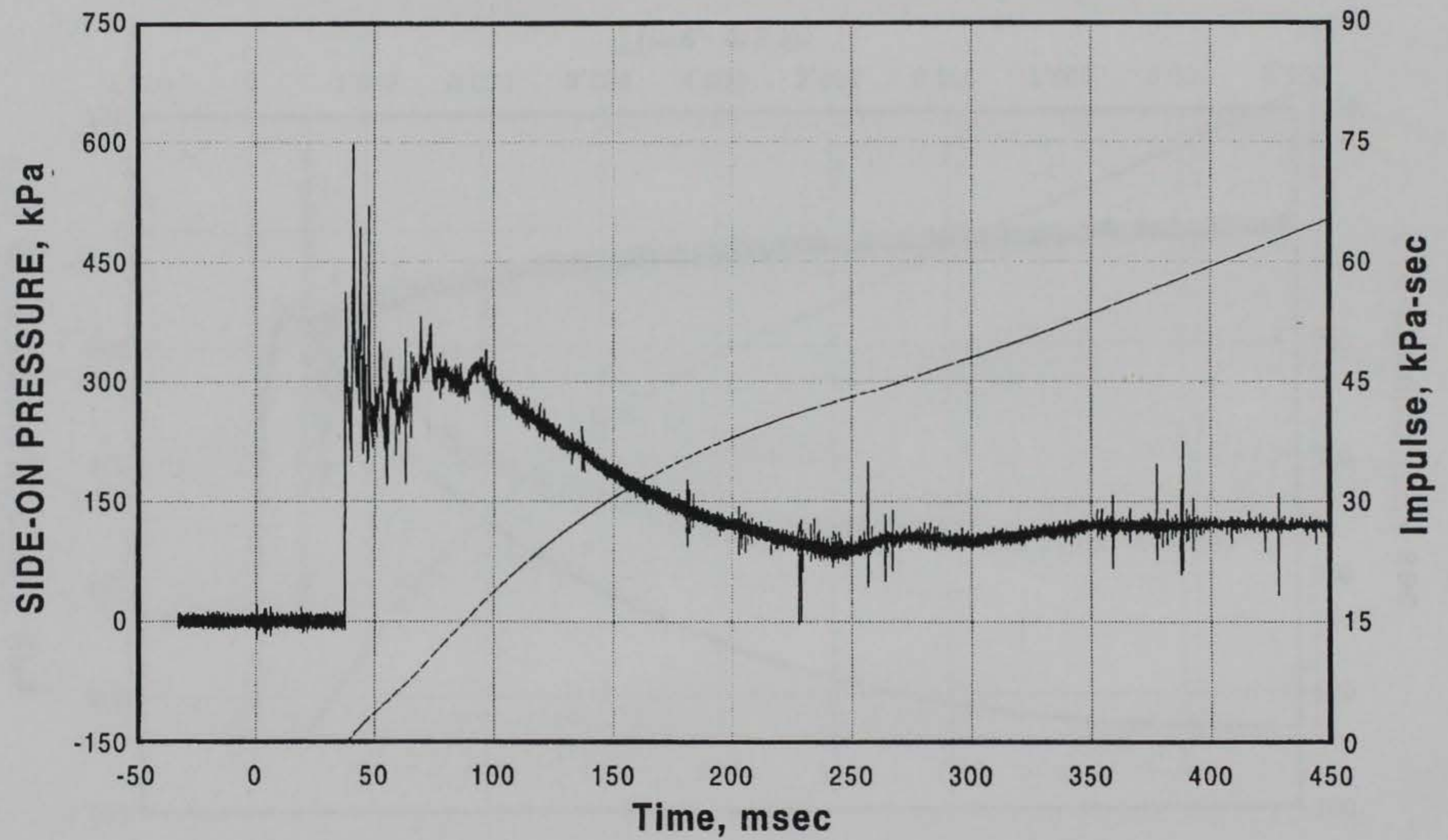

Figure B9. Gage 11ABSO airblast overpressure- and impulse-time-histories (450 msec record), Singapore Ground Shock Test. 


\section{ABSO REPUBLIC OF SINGAPORE GROUND SHOCK TEST}

06-18-1996 02:00:35

Cal val $=250.7745, \mathrm{CBS}=\mathbf{0} .290136$

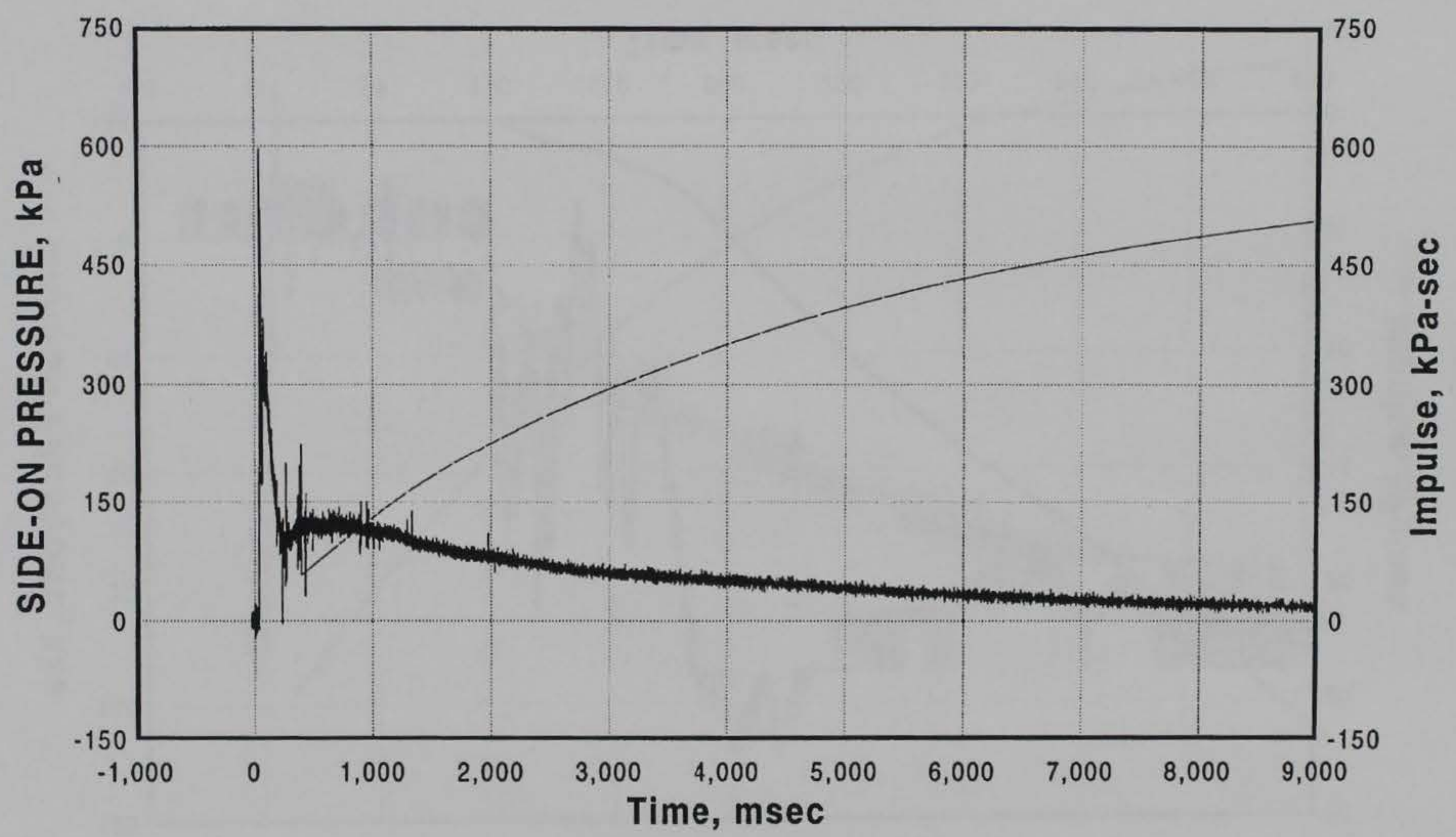

Figure B10. Gage 11ABSO airblast overpressure- and impulse-time-histories ( 9 sec record), Singapore Ground Shock Test. 
06-18-1996 02:00:35

Cal val $=97.76835, \mathrm{CBS}=0.0657466$

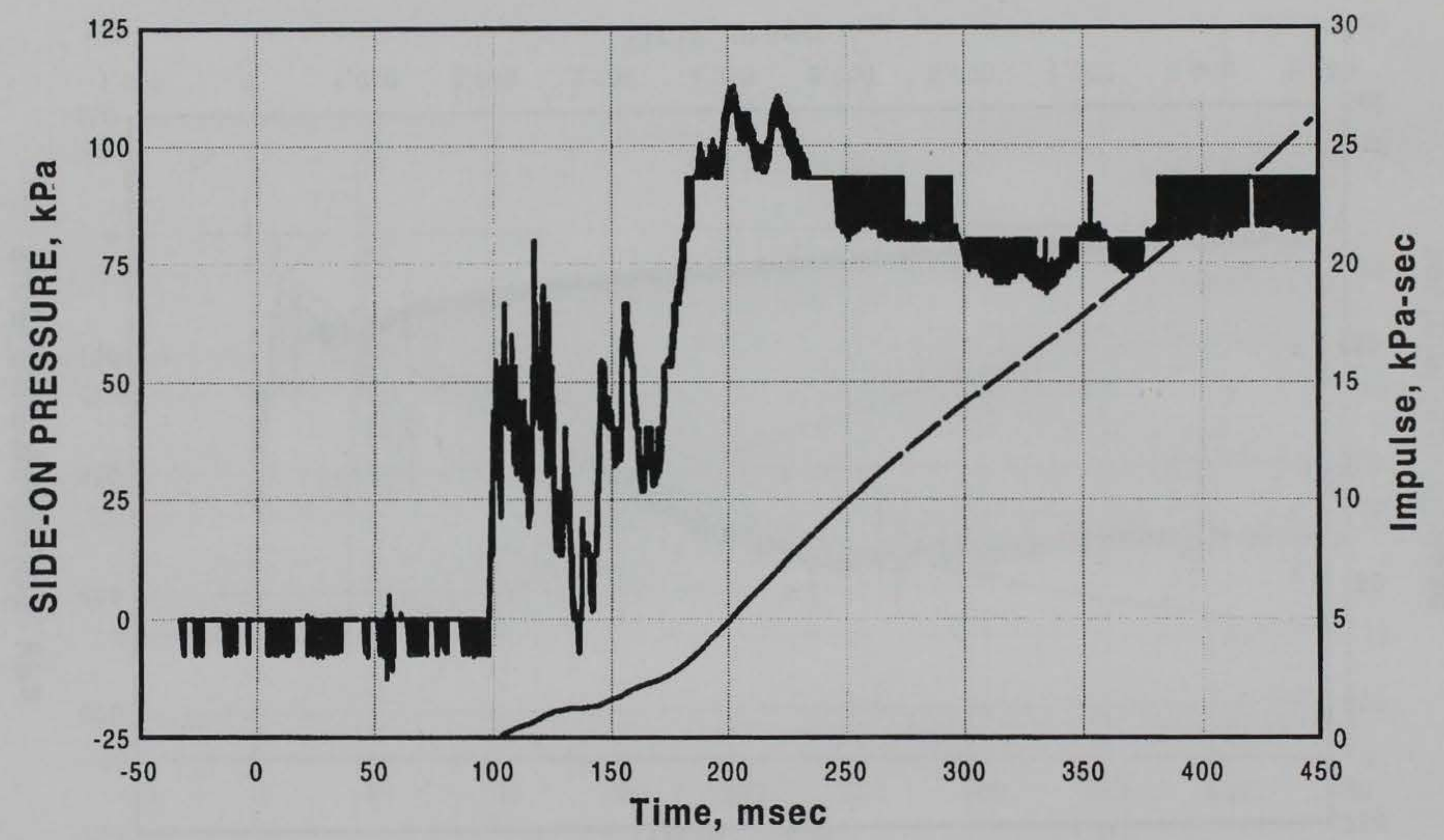

Figure B11. Gage 10A-ABSO airblast overpressure- and impulse-time-histories (450 msec record), Singapore Ground Shock Test. 


\section{A-ABSO REPUBLIC OF SINGAPORE GROUND SHOCK TEST}

06-18-1996 02:00:35

Cal val $=97.76835$, CBS $=0.0657466$

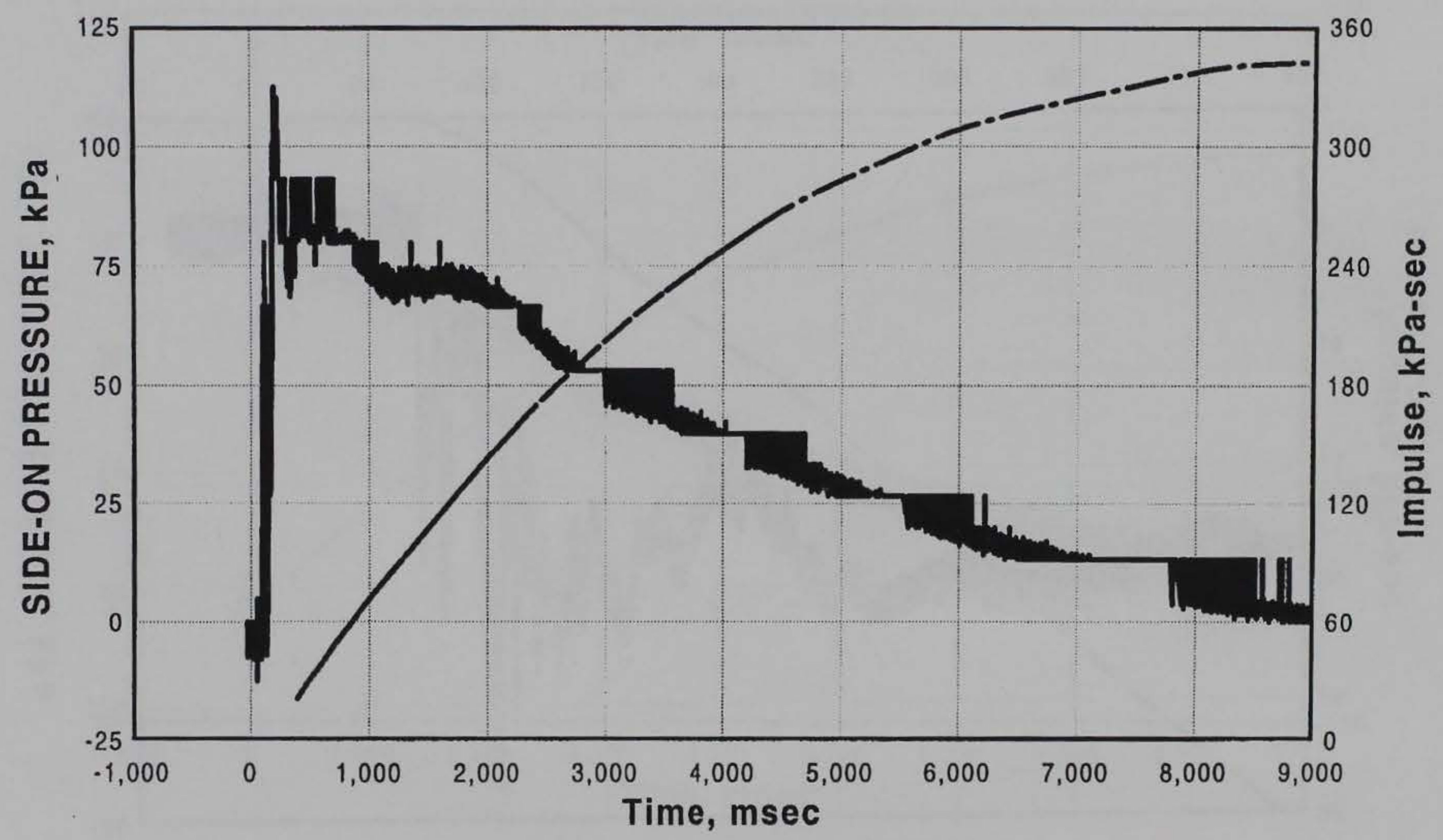

Figure B12. Gage 10A-ABSO airblast overpressure- and impulse-timehistories (9 sec record), Singapore Ground Shock Test. 
10B-ABSO REPUBLIC OF SINGAPORE GROUND SHOCK TEST 06-18-1996 02:00:35

Cal val $=125.2923, \mathrm{CBS}=0.00524016$

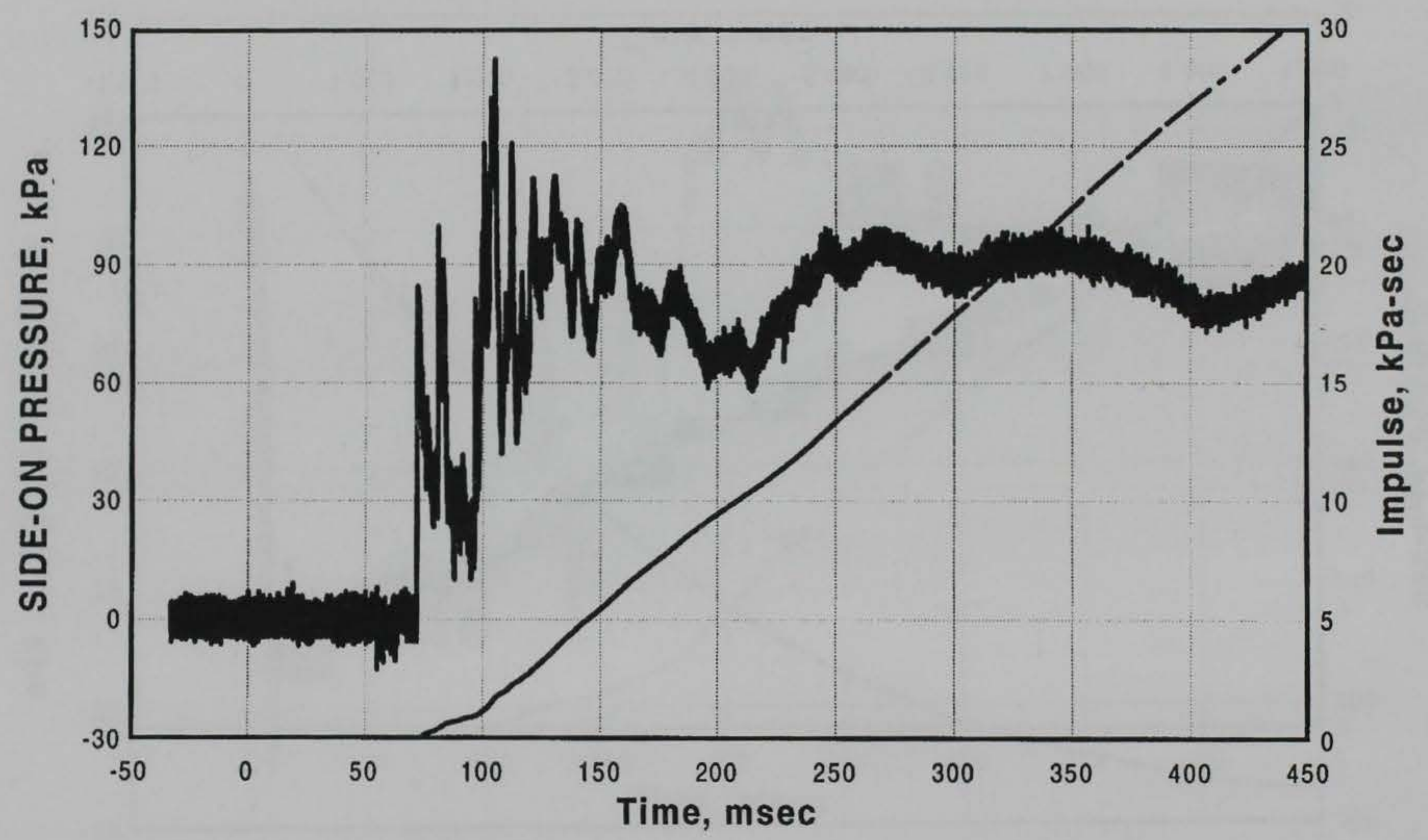

Figure B13. Gage 10B-ABSO airblast overpressure- and impulse-time-histories (450 msec record), Singapore Ground Shock Test. 
10B-ABSO REPUBLIC OF SINGAPORE GROUND SHOCK TEST 06-18-1996 02:00:35

Cal val $=125.2923, \mathrm{CBS}=0.00524016$

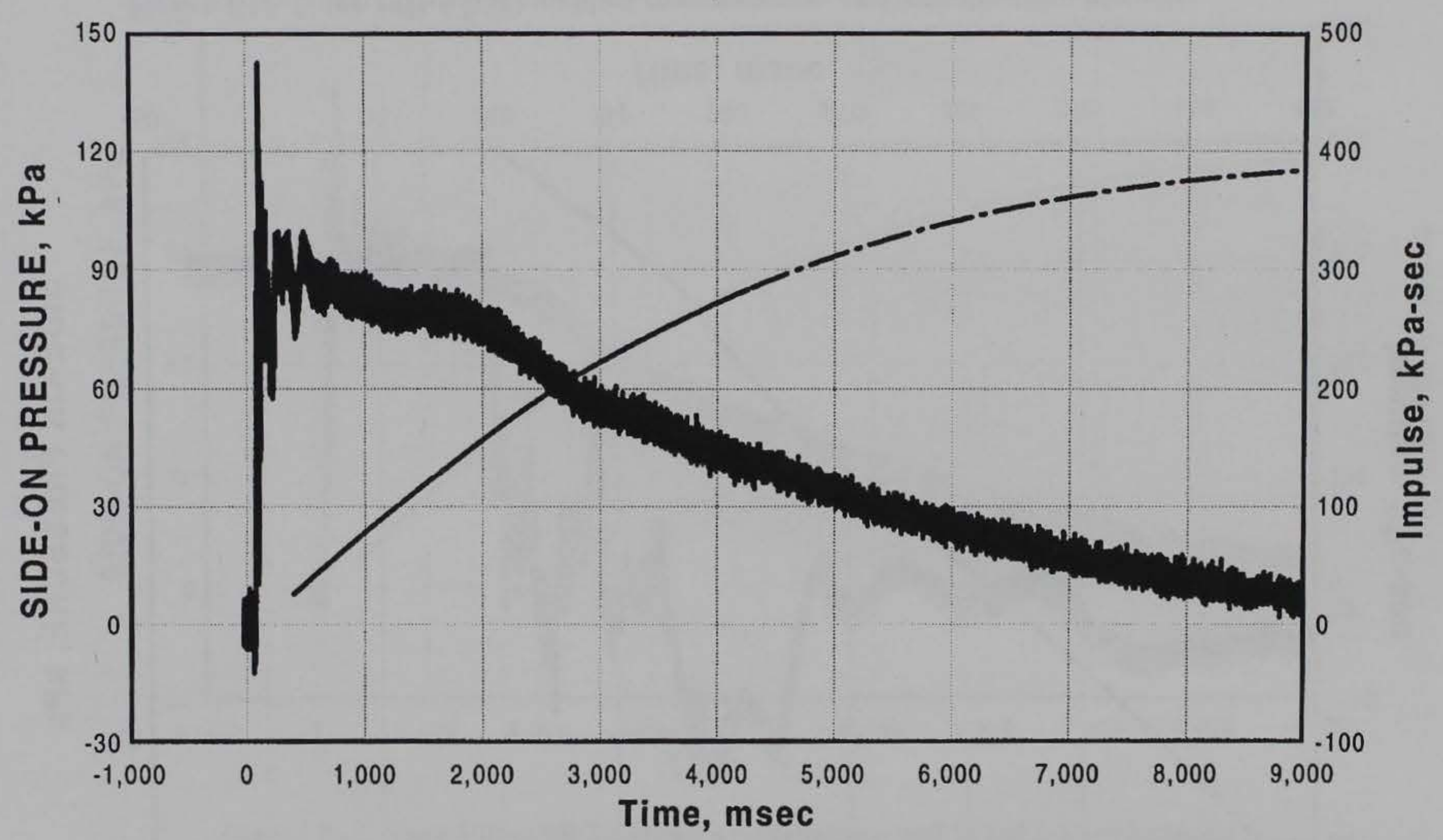

Figure B14. Gage 10B-ABSO airblast overpressure- and impulse-time-histories (9 sec record), Singapore Ground Shock Test. 
10D-ABSO REPUBLIC OF SINGAPORE GROUND SHOCK TEST

06-18-1996 02:00:35

Cal val $=97.71223$, CBS $=0.00724495$

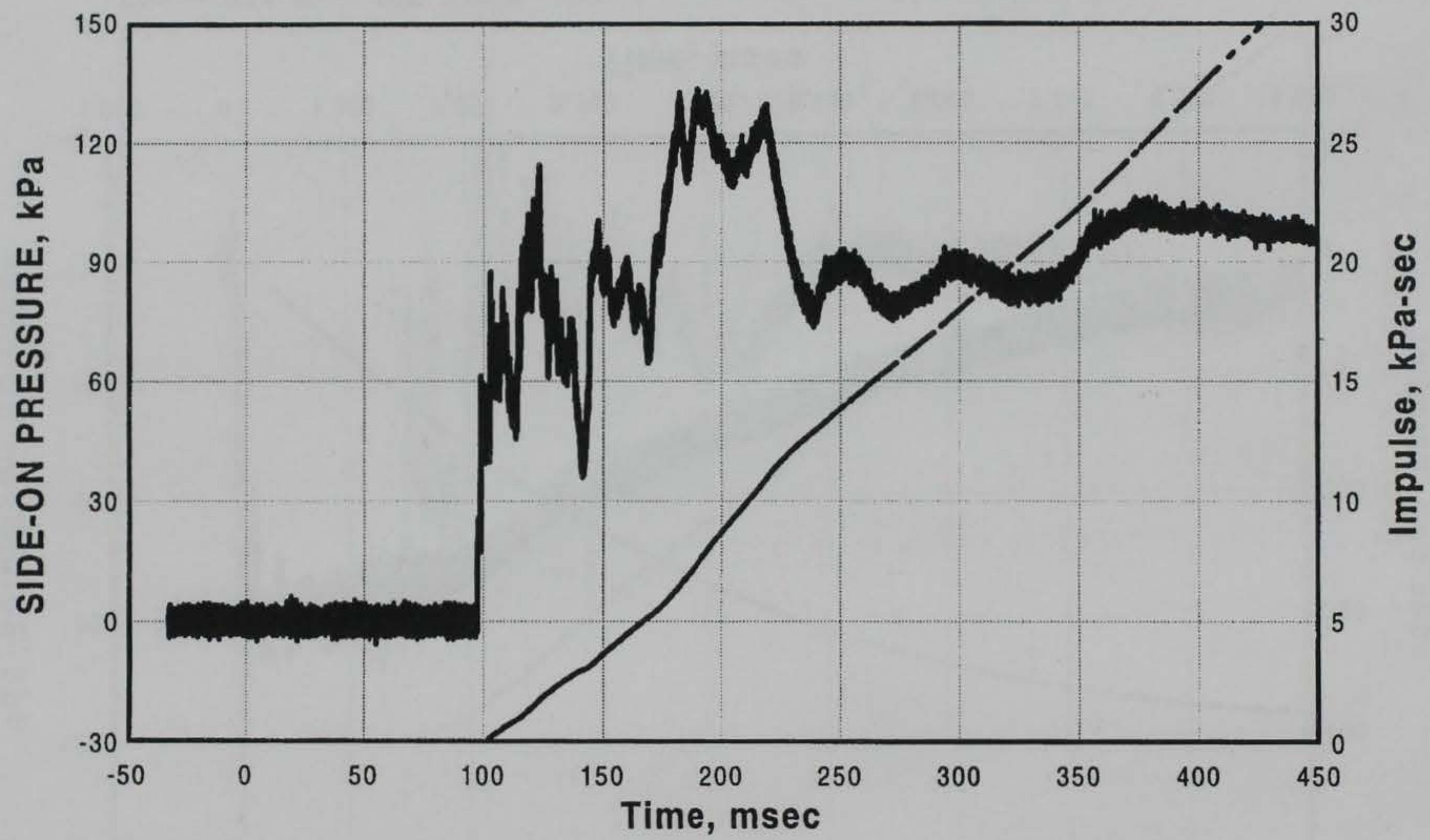

Figure B15. Gage 10D-ABSO airblast overpressure- and impulse-time-histories (450 msec record), Singapore Ground Shock Test. 
Cal val $=97.71223, \mathrm{CBS}=0.00724495$

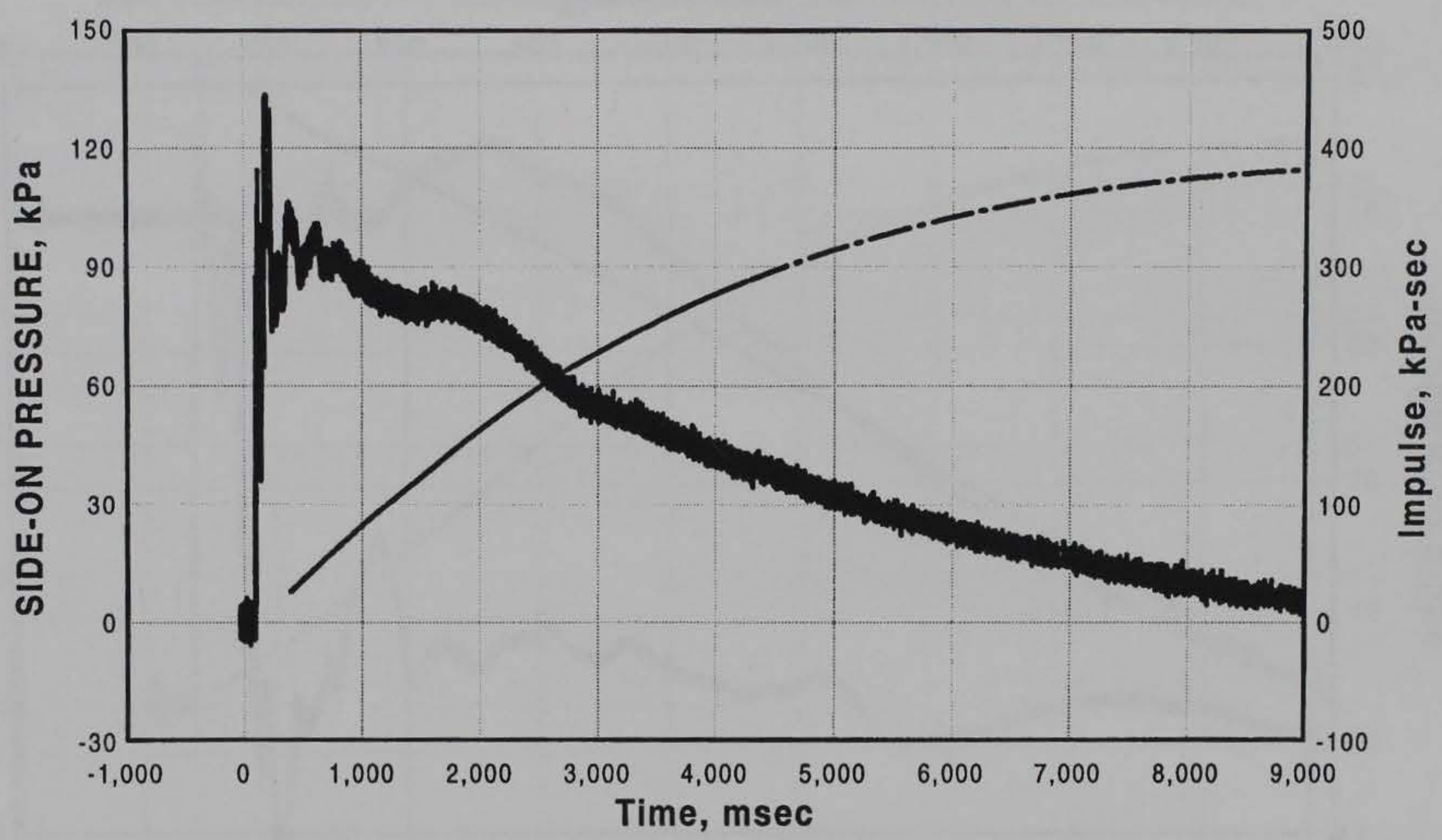

Figure B16. Gage 10D-ABSO airblast overpressure- and impulse-time-histories (9 sec record), Singapore Ground Shock Test. 


\section{ABSO REPUBLIC OF SINGAPORE GROUND SHOCK TEST}

06-18-1996 02:00:35

Cal val=28.09811, CBS=0.0338342 from -32.764 to 12844.03

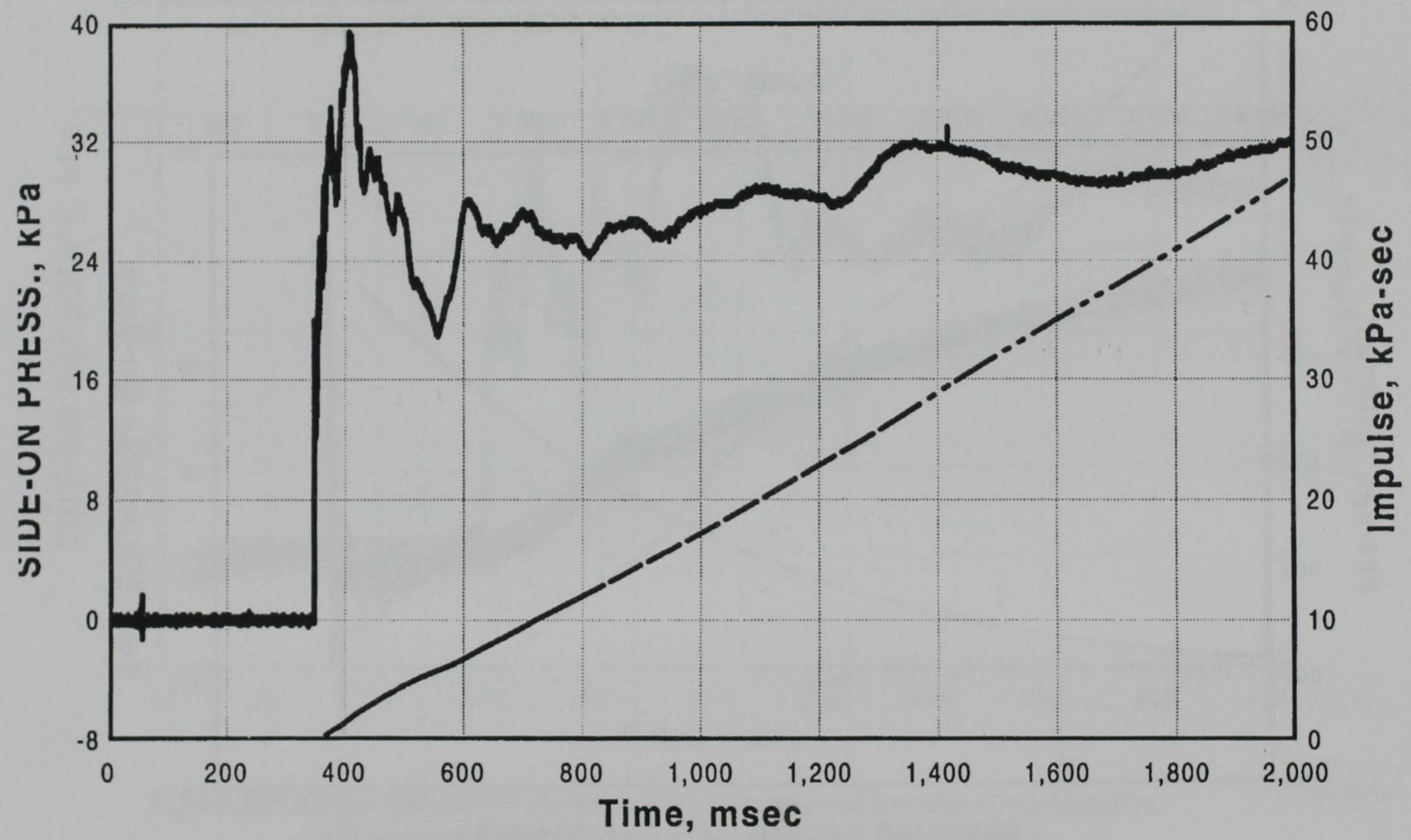

Figure B17. Gage 4ABSO airblast overpressure- and impulse-time-histories (2 sec record), Singapore Ground Shock Test. 


\section{ABSO REPUBLIC OF SINGAPORE GROUND SHOCK TEST}

06-18-1996 02:00:35

Cal val $=28.09811$, CBS $=0.0338342$ from -32.764 to 12844.03

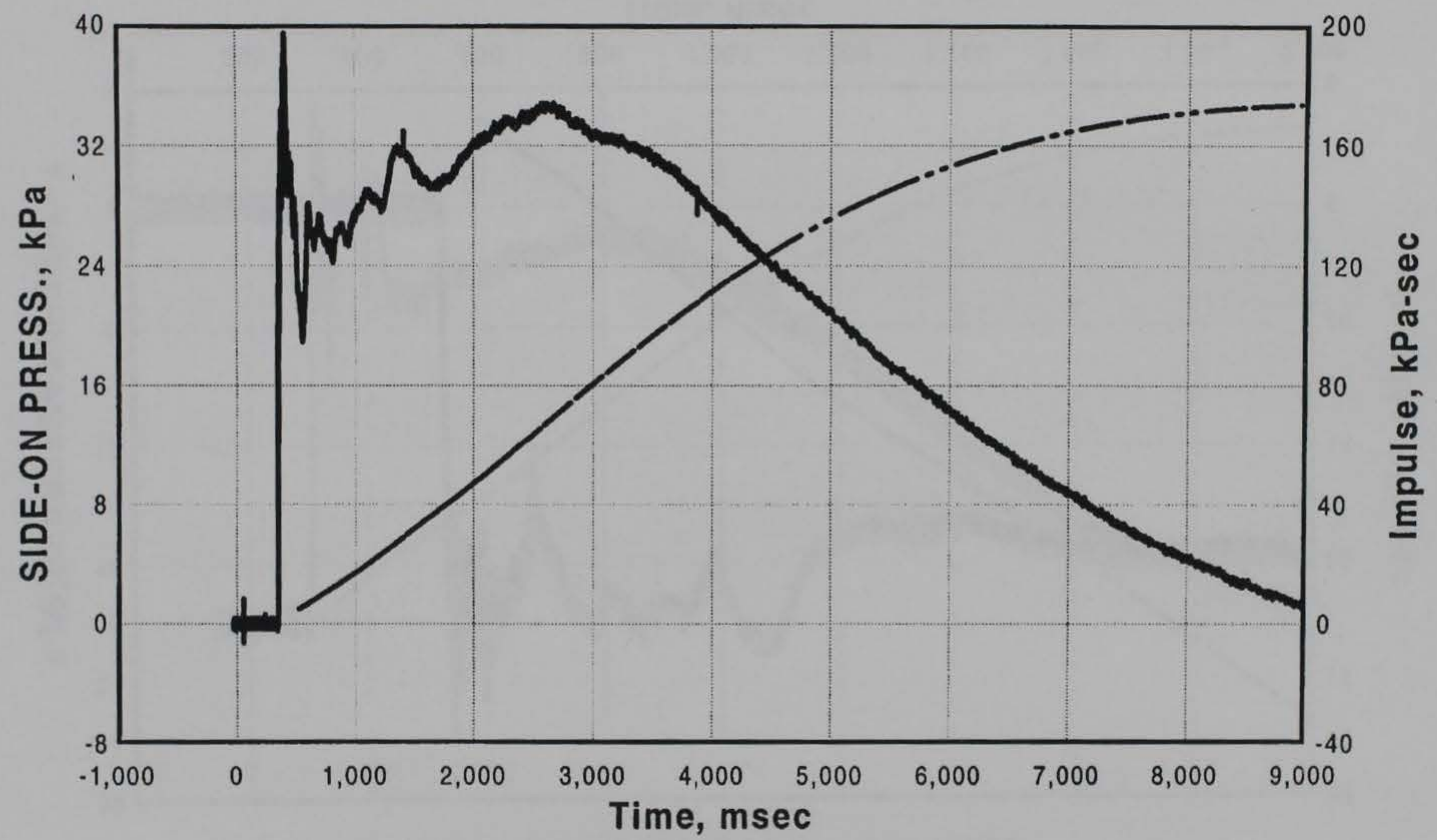

Figure B18. Gage 4ABSO airblast overpressure- and impulse-time-histories ( 9 sec record), Singapore Ground Shock Test. 
06-18-1996 02:00:35

Cal val $=15.81394$, CBS $=0.00659208$

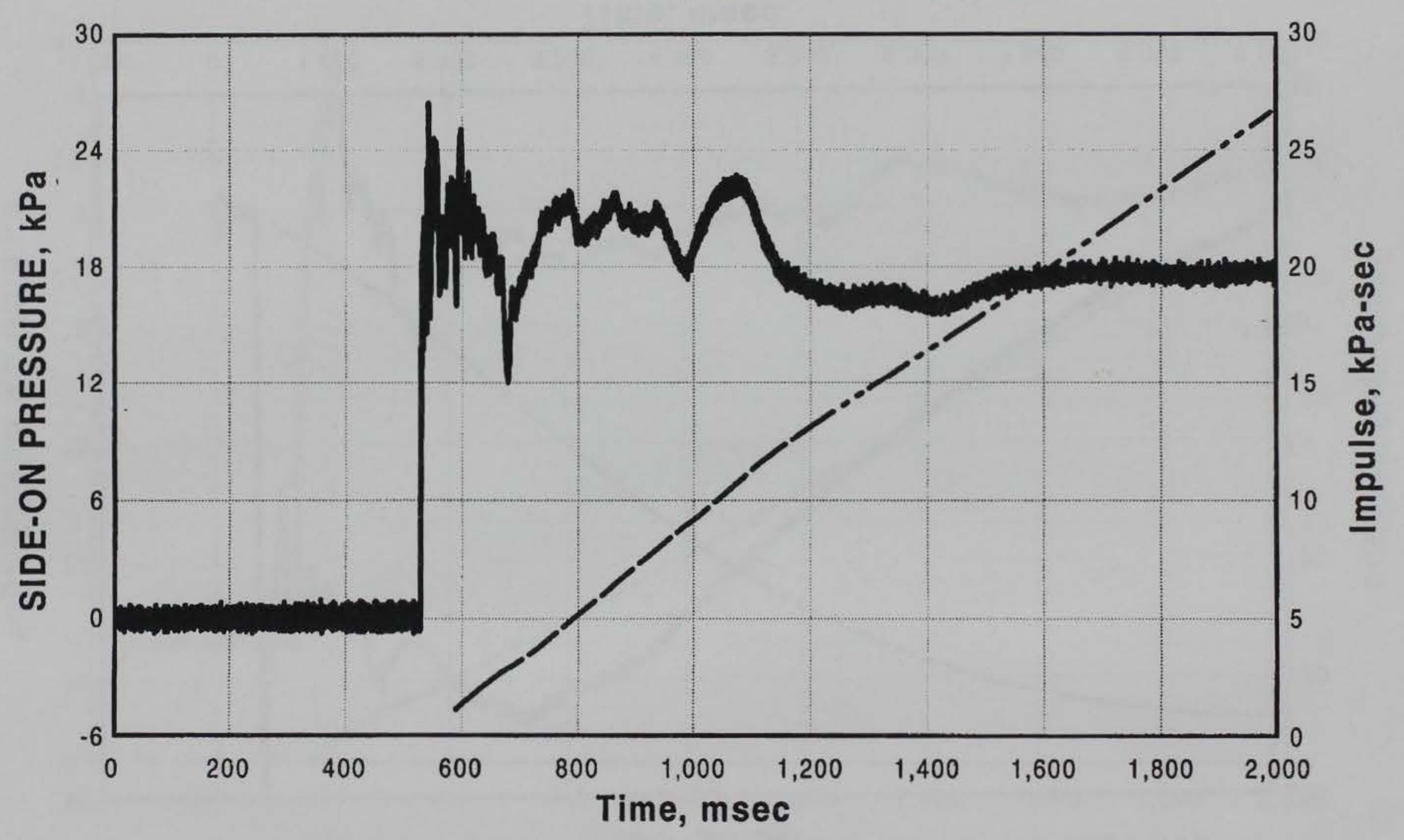

Figure B19. Gage 3ABSO airblast overpressure- and impulse-time-histories (2 sec record), Singapore Ground Shock Test. 


\section{ABSO REPUBLIC OF SINGAPORE GROUND SHOCK TEST}

06-18-1996 02:00:35

Cal val $=15.81394, \mathrm{CBS}=0.00659208$

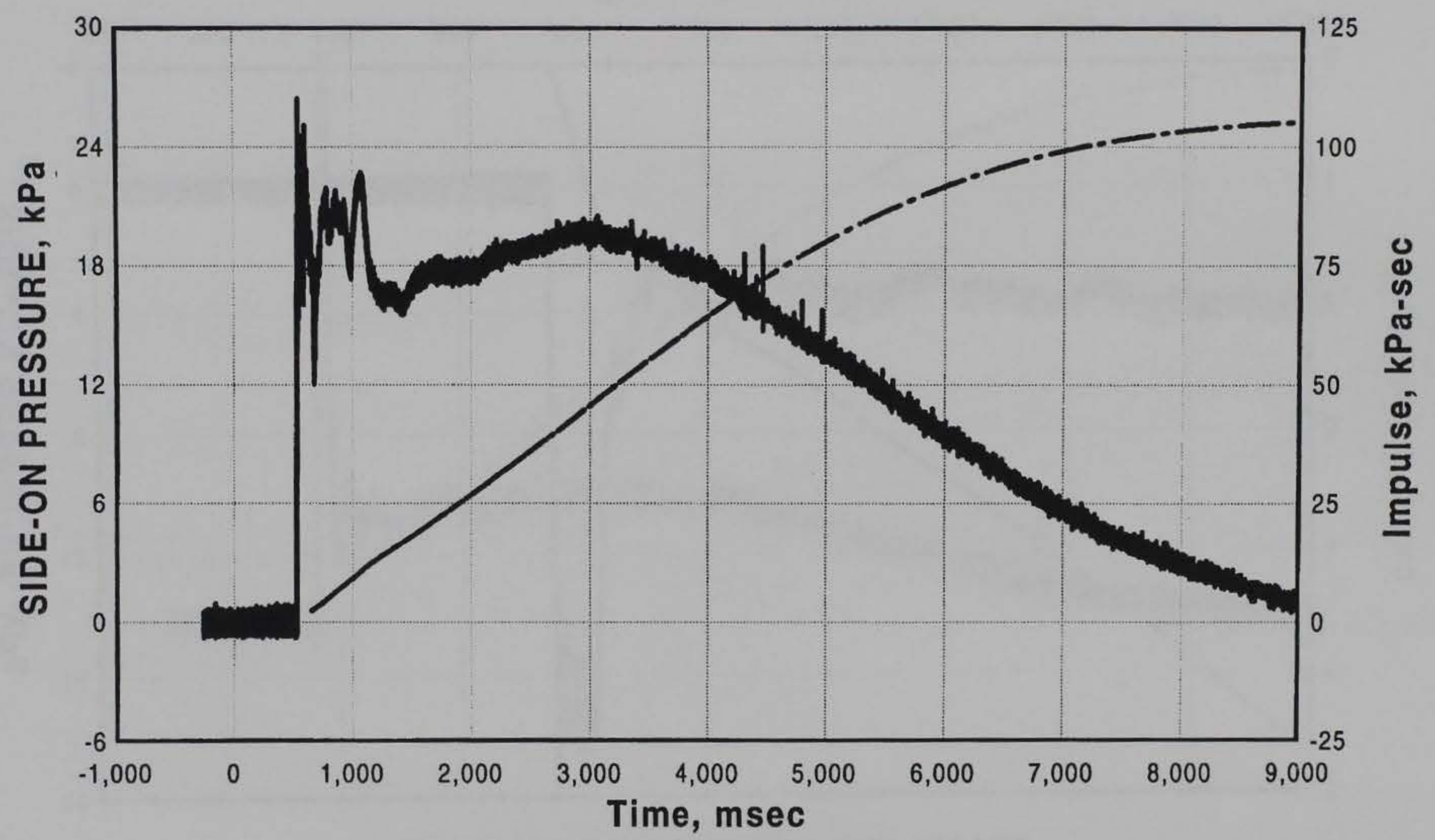

Figure B20. Gage 3ABSO airblast overpressure- and impulse-time-histories (9 sec record), Singapore Ground Shock Test. 
Cal val $=10.50718, C B S=-0.00128758$

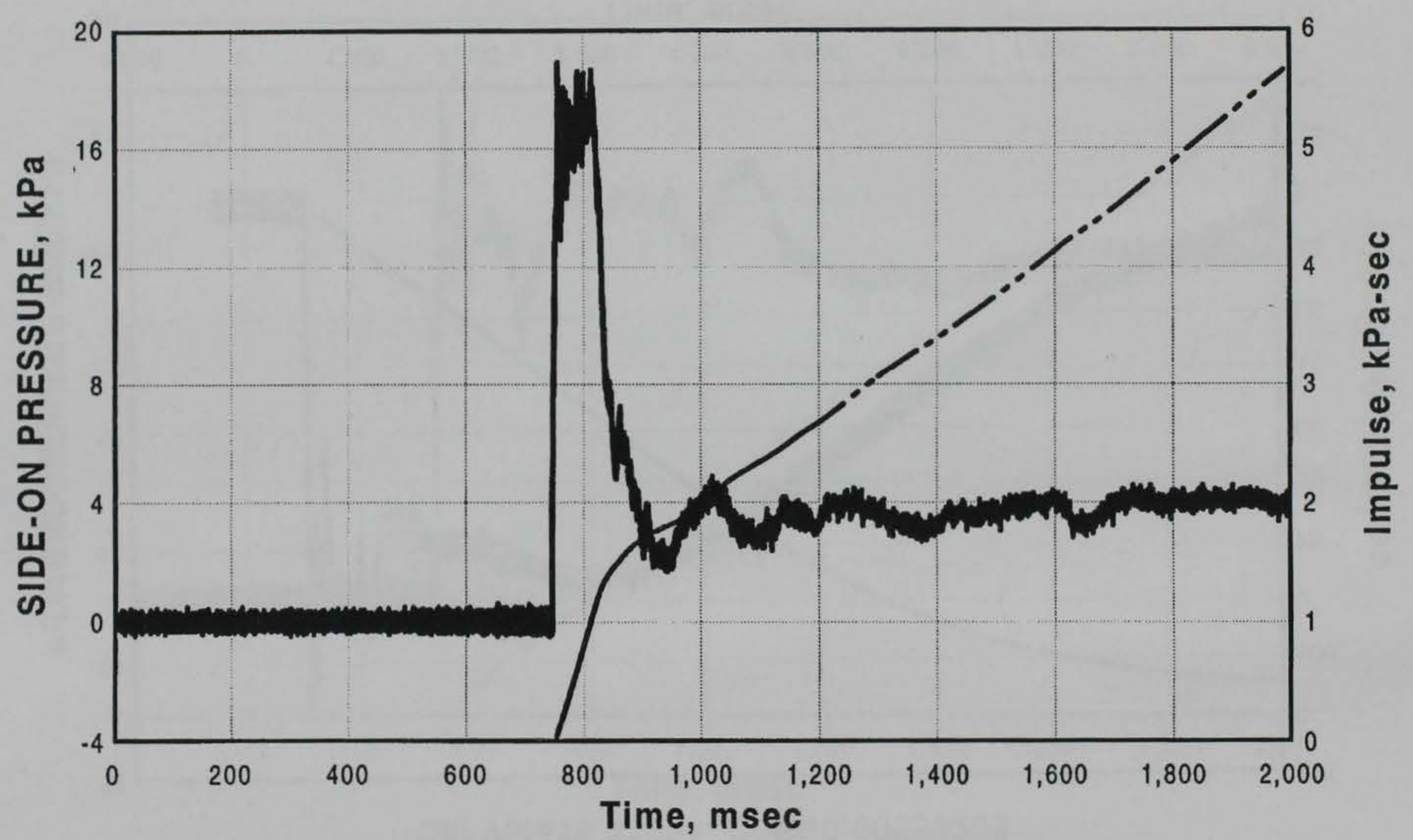

Figure B21. Gage 1ABSO airblast overpressure- and impulse-time-histories (2 sec record), Singapore Ground Shock Test. 
1 ABSO REPUBLIC OF SINGAPORE GROUND SHOCK TEST

06-18-1996 02:00:35

Cal val $=10.50718, C B S=-0.00128758$

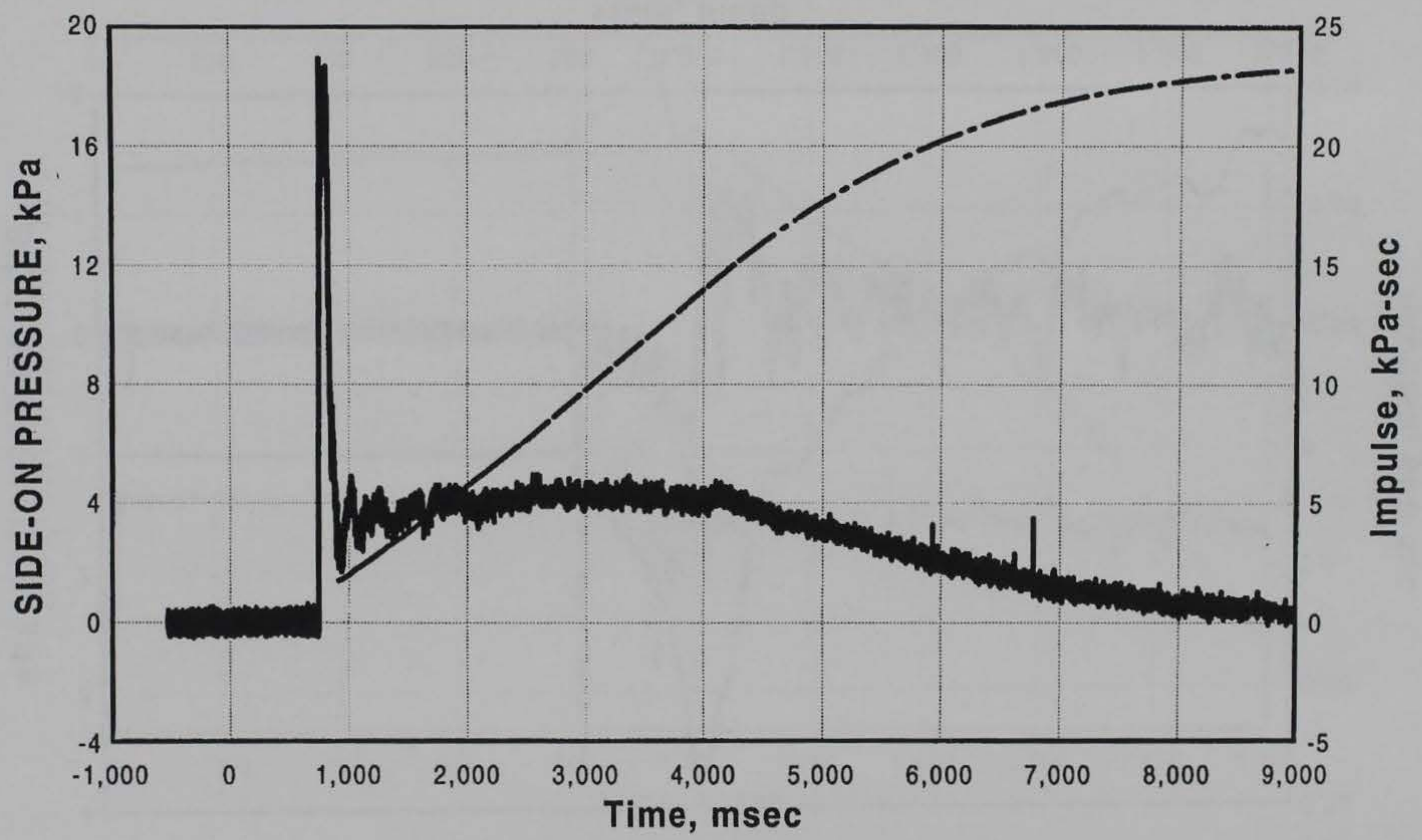

Figure B22. Gage 1ABSO airblast overpressure- and impulse-time-histories (9 sec record), Singapore Ground Shock Test. 

06-18-1996 02:00:35

Cal val $=0.5007814$, CBS $=-0.00587689$

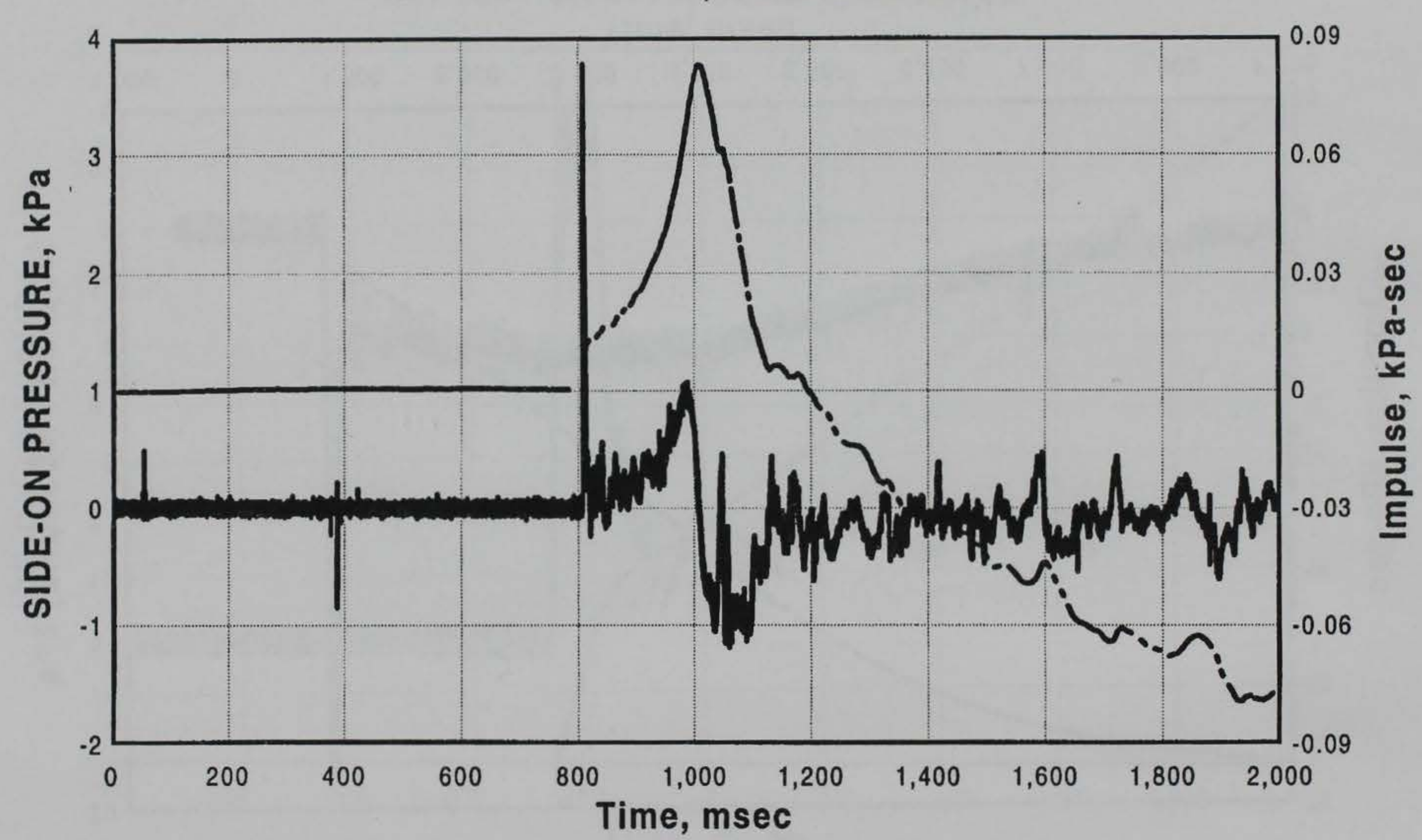

Figure B23. Gage 59ABSO free-field overpressure- and impulse-time-histories (2 sec record), Singapore Ground Shock Test. 
60ABSO REPUBLIC OF SINGAPORE GROUND SHOCK TEST

06-18-1996 02:00:35

Cal val $=0.2948767$, CBS $=-0.222867$

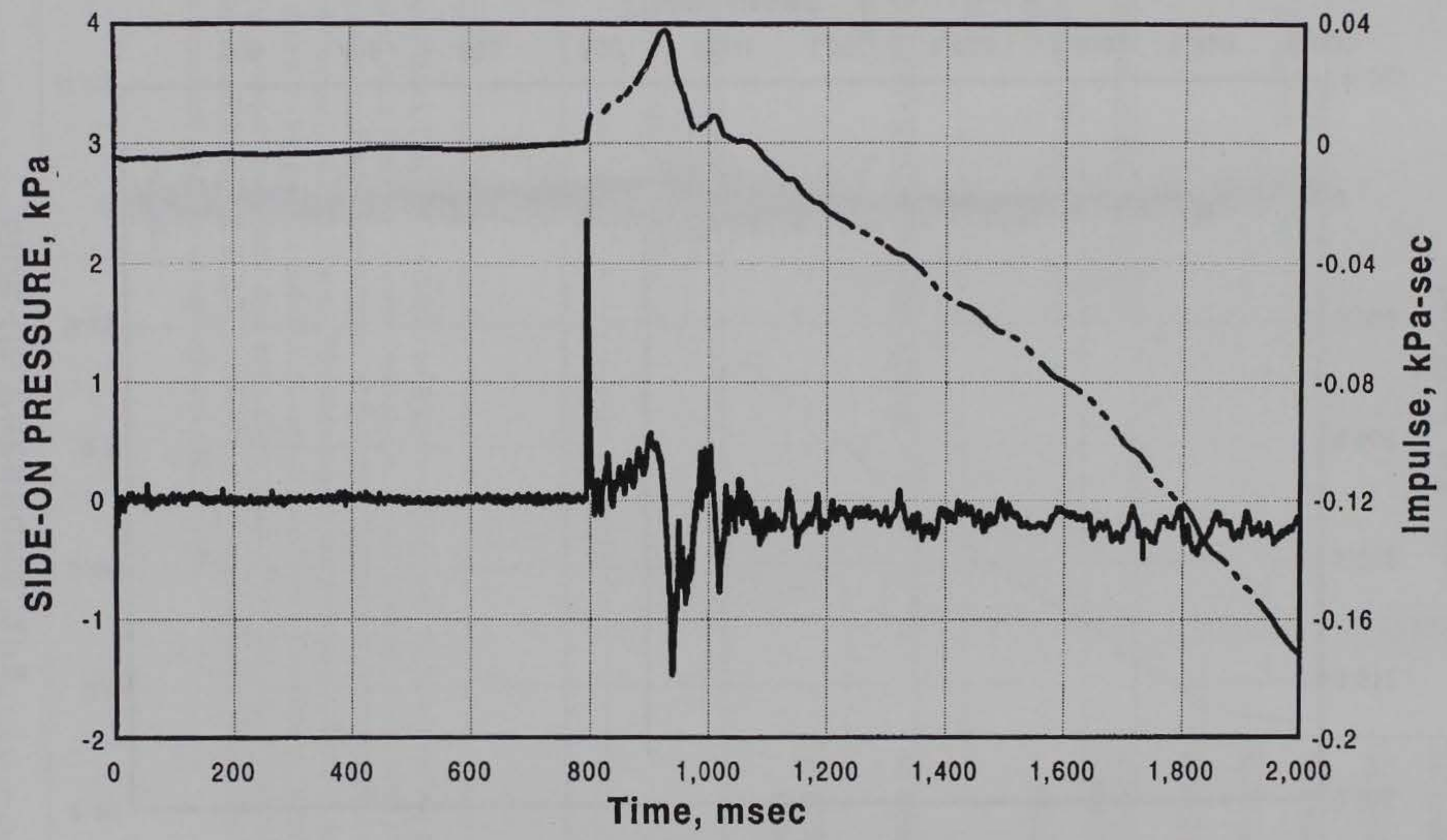

Figure B24. Gage 60ABSO free-field overpressure- and impulse-time-histories (2 sec record), Singapore Ground Shock Test. 


\section{ABSO REPUBLIC OF SINGAPORE GROUND SHOCK TEST}

06-18-1996 02:00:35

Cal val $=0.1144909, \mathrm{CBS}=-0.00388012$

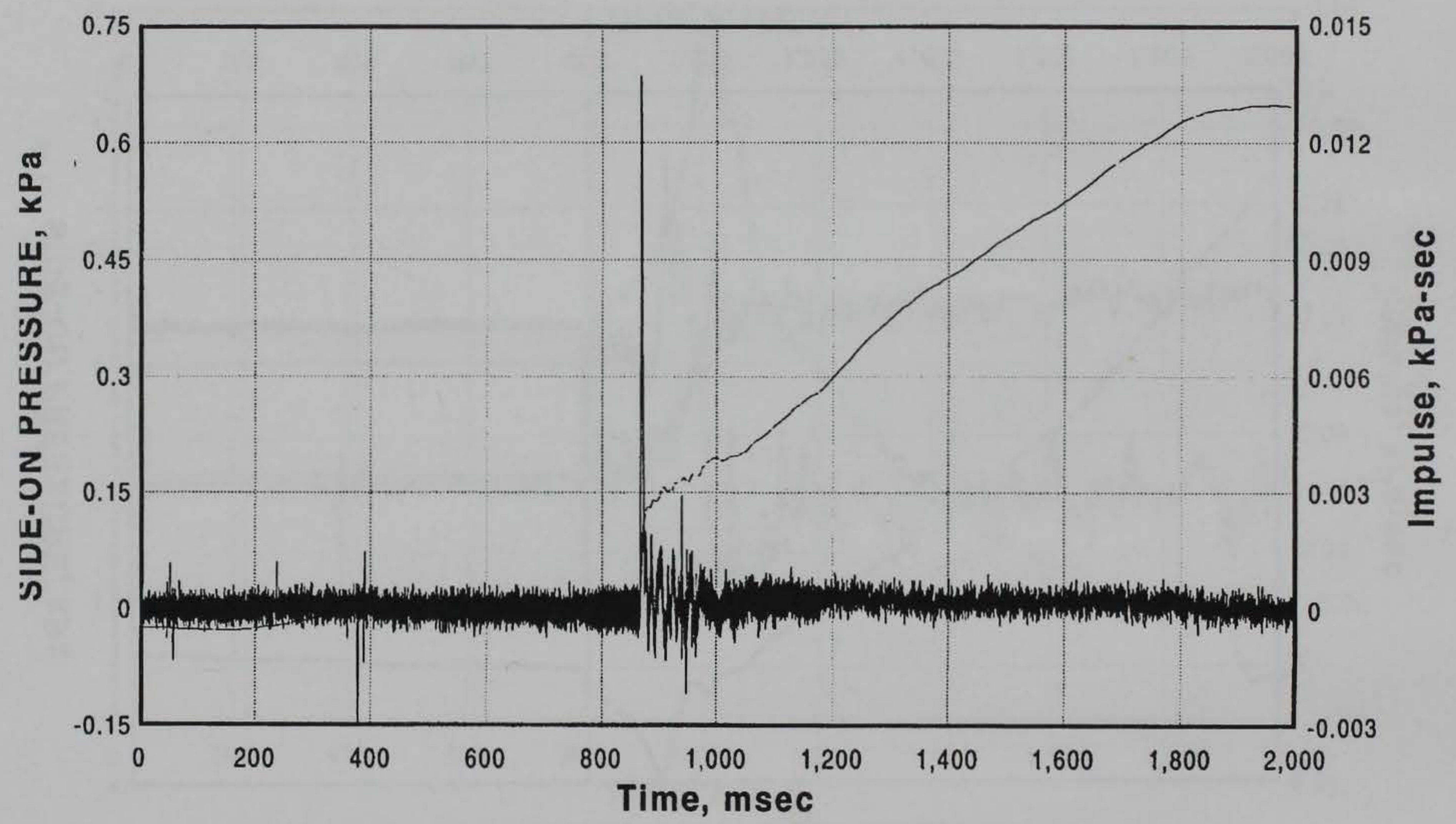

Figure B25. Gage 63ABSO free-field overpressure- and impulse-time-histories (2 sec record), Singapore Ground Shock Test. 


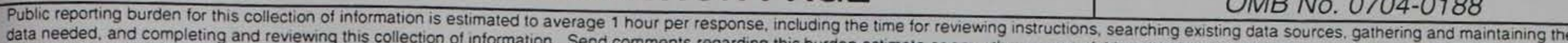

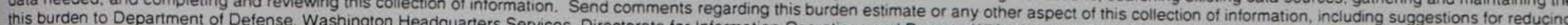

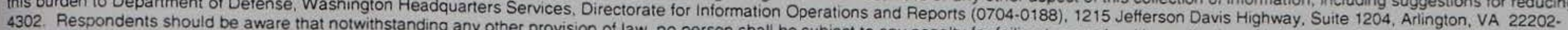

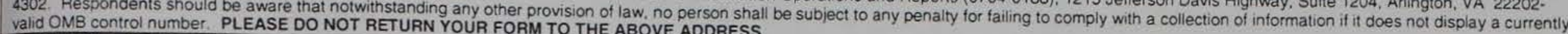
1. REPORT DATE (DD-MM-YYYY)
April 2000
Final report
3. DATES COVERED (FrOm - TO)

4. TITLE AND SUBTITLE

1996 Singapore Ground Shock Test

5a. CONTRACT NUMBER

5b. GRANT NUMBER

5c. PROGRAM ELEMENT NUMBER

\section{AUTHOR(S)}

Donald W. Murrell, Charles E. Joachim

5d. PROJECT NUMBER

5e. TASK NUMBER

5f. WORK UNIT NUMBER

8. PERFORMING ORGANIZATION REPORT NUMBER

ERDC/SL TR-00-1

U.S. Army Engineer Research and Development Center

Waterways Experiment Station

3909 Halls Ferry Road

Vicksburg, MS 39180-6199

\section{SPONSORING / MONITORING AGENCY NAME(S) AND ADDRESS(ES)}

Lands and Estates Organization

Ministry of Defence

1 Depot Road, \#12-05

Singapore 109679

Republic of Singapore

\section{DISTRIBUTION / AVAILABILITY STATEMENT}

Approved for public release, distribution unlimited.

\section{SUPPLEMENTARY NOTES}

\section{ABSTRACT}

The 1996 Singapore Ground Shock Test was conducted to document the ground shock and surface ground motions produced by a simulated accidental detonation of munitions in a $1 / 3$-scale underground storage chamber at a nominal loading density of $10 \mathrm{~kg} / \mathrm{cubic}-\mathrm{m}$. A secondary objective was to record the airblast levels produced in the connecting tunnels and beyond the tunnel portal. The explosive charge consisted of $696.6 \mathrm{~kg}$ of Composition B explosive. The test chamber was located at a depth of approximately $115 \mathrm{~m}$ in a limestone geology. The ground motion data from the gages installed in the vertical boorehole are in good agreement with data from previous experiments (UAST) at this site. Comparison of these data and surface values shows that both sets attenuate at the rate of distance to the2.5 power. The surface motion reflection factor is slightly greater than the theoretical free-surface value but is in good agreement with reflection factors of 3 to 5 that have been observed on underground nuclear tests.

\section{SUBJECT TERMS}

Ammunition storage, Ground shock, Seismic ground motions, Surface ground motions, Underground magazines

\begin{tabular}{|c|c|c|c|c|c|}
\hline \multicolumn{3}{|c|}{ 16. SECURITY CLASSIFICATION OF: } & \multirow{3}{*}{$\begin{array}{l}\text { 17. LIMITATION } \\
\text { OF ABSTRACT }\end{array}$} & \multirow{3}{*}{$\begin{array}{l}\text { 18. NUMBER } \\
\text { OF PAGES }\end{array}$} & 19a. NAME OF RESPONSIBLE PERSON \\
\hline a. REPORT & & c. THIS PAGE & & & $\begin{array}{l}\text { 19b. TELEPHONE NUMBER (include area } \\
\text { code) }\end{array}$ \\
\hline UNCLASSIFIED & UNCLASSIFIED & UNCLASSIFIED & & & \\
\hline
\end{tabular}

